\title{
Recurrent abdominal pain in children
}

Citation for published version (APA):

van der Meer, S. B. (1991). Recurrent abdominal pain in children. [Doctoral Thesis, Maastricht University]. Academisch Ziekenhuis Maastricht, afd. Kindergeneeskunde. https://doi.org/10.26481/dis.19910314sm

Document status and date:

Published: 01/01/1991

DOI:

10.26481/dis. $19910314 \mathrm{sm}$

Document Version:

Publisher's PDF, also known as Version of record

\section{Please check the document version of this publication:}

- A submitted manuscript is the version of the article upon submission and before peer-review. There can be important differences between the submitted version and the official published version of record.

People interested in the research are advised to contact the author for the final version of the publication, or visit the DOI to the publisher's website.

- The final author version and the galley proof are versions of the publication after peer review.

- The final published version features the final layout of the paper including the volume, issue and page numbers.

Link to publication

\footnotetext{
General rights rights.

- You may freely distribute the URL identifying the publication in the public portal. please follow below link for the End User Agreement:

www.umlib.nl/taverne-license

Take down policy

If you believe that this document breaches copyright please contact us at:

repository@maastrichtuniversity.nl

providing details and we will investigate your claim.
}

Copyright and moral rights for the publications made accessible in the public portal are retained by the authors and/or other copyright owners and it is a condition of accessing publications that users recognise and abide by the legal requirements associated with these

- Users may download and print one copy of any publication from the public portal for the purpose of private study or research.

- You may not further distribute the material or use it for any profit-making activity or commercial gain

If the publication is distributed under the terms of Article $25 \mathrm{fa}$ of the Dutch Copyright Act, indicated by the "Taverne" license above, 


\section{RECURRENT ABDOMINAL PAIN IN CHILDREN}

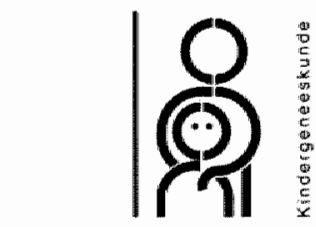

Vakgroep Kindergeneeskunde 


\title{
RECURRENT ABDOMINAL PAIN IN CHILDREN
}

\author{
PROEFSCHRIFT
}

Ter verkrijging van de graad van doctor aan de Rijksuniversiteit Limburg te Mastricht op gezag. van de Rector Magnificus, Prof.Mr. M.J. Cohen, volgens het besluit van het College van Dekanen,

in het openbatar te verdedigen

op donderdag, 14 maart 1991 om 16.00 uur

door

Sybrandus Bonifacius van der Meer

geboren te Witmarsum (Fil)

op 19 november 1953 
Promotores:

Co-promotor:

Beoordelingscommissie: Prof.Dr. P.B. Soeters, voorzitter

Prof.Dr. J.J.C.B. Bremer

Prof, Dr. J.M.A. van Engelshoven

Prof.Dr. H.S.A. Heymans (Rijksuniversiteit Groningen)

Prof.Dr. E.D.A.M. Schretlen (Rijksuniversiteit Nijmegen)

\section{CIP-DATA KONINKLIJKE BIBLIOTHEEK, DEN HAAG}

Meer, Sybrandus Bonifacius van der

Recument abdominal pain in children / Sybrandus Bonifacius van der Meer, Iadapt. and ill. by Guus van Rooyl. - Maastricht; Academisch Ziekenhuis Maastricht, afd. Kindergeneeskunde. - ill.

Thesis Matastricht. - with ref. - With summary in Dulch and Frisian.

ISBN $90-9003992-9$

Subject heading: recurtent abdominal pain; children.

Foto omslag: S.B. van der Meer

Druk: Drukkerij Groenevelt, Landgraaf

Het in dit proefschrilt beschreven onderzoek werd mede mogelijk gemaakt dankzij flunancièle steun van Milupa Nederland bv en Glaxo bv. 
The ill child is ill all over

(Apley, 1975)

In memory of Prof.Dr. L.H.J. Ramatekers

lin memory of my father

To my mother 


\section{Voorwoord}

Toen mijn opleider wijlen Prof.Dr. L.H.J. Ramaekers in 1984 tot mij sprak en zei: "Syb, jij gaat dat buikpijnonderzoek doen", kon ik niet vermoeden wat voor consequenties mijn gretig antwoord: "dat lijkt me leuk", met zich meebracht. Maar uiteindelijk heeft dat toch geresulteerd in het proefschrift zoals dat voor U ligt.

Begonnen als een idee van Prof.Dr. L.H.J. Ramaekers en Dr. P.P. Forget ging het buikpijnonderzoek in 1985 op de kinderafdeling van het Academisch Ziekenhuis Maastricht van start. In de loop der jaren zijn de nodige mensen bij het onderzoek betrokken geweest.

In de eerste plaats de helaas veel te vroeg overleden Prof.Dr. L.H.J. Ramaekers. Hij zou bijzonder trots zijn geweest op dit eindresultaat van zijn project. Zelfs in de periode dat hij afwezig was door zijn ziekte liet hij zijn betrokkenheid merken door regelmatig te informeren naar de vorderingen. Als mijn opleider heeft hij een belangrijke bijdrage geleverd aan mijn vorming tot kinderarts.

Zijn opvolger, Prof.Dr. R.H. Kuijten, nam met ingang van 1 mei 1988 de rol van promotor op zich. Hooggeleerde Kuijlen, beste René, met jouw komst is het onderzock en de verwerking van de resultaten in een hogere versnelling geraakt. Ik ben je dankbatar voor de mogelijkheden die mij geboden werden binnen de beperkte bezelting van onze afdeling. Als jouw eerste promovendus spreek ik de wens uit dat er nog velen zullen volgen.

Mijn tweede promotor, Prof.Dr. J.W. Arends heelt een wezenlijke rol vervuld in de totstandkoming van dit proefschrift. Hooggeleerde Arends, beste Jan-Willem, de snelheid en gedegenheid watrmee jij de meest uiteenlopende onderwerpen van commentaar voorzag, heeft bij mij veel respect afgedwongen. Het denkbeeld dat ik sneller nieuwe versies van de verschillende hoofdstukken kon aanleveren dan jij kon becommentariëren, heb ik reeds in een vroeg stadlium moeten herzien. Ik hoop dat wij ook in de loekornst nog veel samen mogen werken.

Mijn co-promotor Dr. P.P. Forget, heeft vanal het begin aan mijn zijde gestitan. Zeergeleerde Forget, beste Philippe, als inhoudsdeskundige bij uitstek heb jij gestalle gegeven aan dit proefschrift. De ideeën die jij aandroeg gedurende dit onderzoek heeft de richting bepaald waarin het onderzoek zich voltrok. Ik heb veelwuldig mogen profiteren van jouw omvangrijke kennis en ervaring en hoop dat in de komende jaren nog vala te doen. 
De leden van de beoordelingsommissie, Prof.Dr. P.B. Soeters, Prof.Dr. J.J.C.B. Bremer, Prof.Dr. I.M.A. Wan Engelshoven Prof.Dr. H.S.A. Heymans en Prof.Dr. E.D.A.M. Schretlen dank ik woor het kritisch lezen wan het manuscript en de waardevolle adviezen die tot een inhoudelijke verbetering aanleiding hebben gegeven. In de periode warin Prof.Dr. E.D.A.M. Schretlen hier waamemend hoogleraar was, heeft het buikpijnonderzok een stevige impuls gekregen.

De jeugdartsen van de afdeling Jeugdgezondheidszorg van Maastricht ben ik dankbaar voor hun bereid willige medewerking aan het onderzoek. Het voormalig hoofd van de afdeling, mevr. drs. Eckmans en het huidig hoofd drs. Frans Feron, hebben herhaaldelijk hun enthousiasme laten blijken. Hopelijk voldoet het resultaat aan jullie verwachtingen. Onze onwol prezen kinderpsycholoog, drs. A. Ghys, beste Alex, het onderzoek heeft aan betekenis gewonnen door de vakkundige en nauwkeurige wijze waarop jij de kinderen onderzocht en de ouders interviewde. Wij zullen nog veel met elkar werken, hoop ik. Mieke Witte, psychologisch assistente, nam met voortvarendheid testen af bij de kinderen.

Zeergeleerde Gerver, beste Willem-Jan, ik ben je nog altijd dankbaar voor het feit dat je me op de voordelen van de Macintosh hebt gewezen. Ook de vele malen dat je klaarstond om voor mij in te springen en taken van mij ower te nemen hebben veel voor me betekend. Drs. J.J.P. Schrander, beste Jaap, jouw collegiale houding en belangstelling voor het onderzoek hebben het nodige bijgedragen aan het welslagen wan dit project. Binnenkort kun je zelf ervaren hoe het voelt een voorwoord bij je proefschrift te schrijuen.

Drs. A.M. Van den Neucker, beste Anita, jouw anwezigheid als rots in de branding op de afdeling is van onschatbare waarde.

Drs. J.J.E. Hendriks, beste Han, ook al heb je van het buikpijnonderzoek weinig gemerkt, met jou als onze toekomstige kinderlongarts hoop ik nog veel samen te werken en je expertise op de polikliniek te benutten.

Zeergeleerde Pulles-Heintzberger, beste Christien en drs. T.J.M. Hoorntje, beste Theo, het onderwerp staat weliswaar ver van de kindercardiologie, maar jullie bellangstelling was er niet minder om.

Drs. G. Vos, beste Gijs, ondanks de nog maar korte samenwerking heb ik ervaren dat collegialiteit voor jou erg belangrijk is.

Hooggeleerde Blanco, beste Carlos, ik heb het altijd als een voorrecht beschouwd dat ik lijdens mijn opleiding tol kinderarts de neonatologie op jouw afdeling heb mogen ervaren. Daamaast was an ben je voor ons een sterke stimulans tot en initiator van. werenschappelijk onderzoek.

De staf neonatologie: drs. W.I. Maertzdorf, beste Wiel, drs P. Degraeuwe, beste Pieter, drs J. Wesldorp, beste Joke en drs. M.A.H.B.M. van der Hoeven, beste Mark, jullie stonden niet zover van het onderwerp af als men zou vermoeden. Ook met jullie hoop ik nog veel samen te werken in de toekomst.

De arts-assistenten Kindergeneeskunde, jullie begrip voor mijn soms wisselende beschikbaarheid heb ik erg gewardeerd. Dat ik de supervisie op de polikliniek als een belangrijk onderdeel van de opleiding beschouw is jullie bekend.

De verpleegkundige staf wan de polikliniek, de "poli dames" hebben een zeer belangrijke rol gespeeld in de tot stand koming van dit proefschrift. Gaby Segers, Marianne Masset, Carmen Kleynen, Et-may Lahaije en Karla Jooren hebben de afgelopen jaren oneindig goed voon me gezorgd en misschien wel onherstelbaar verwend. Met dit team zie ik de toekomst van de polikliniek zeer zonnig tegemoet.

De verpleegkundigen van de kinderafdeling, te veel om op te noemen, hebben steeds 
enthousiast meegewerkt bij de verzaneling wan patienten en gegewens.

Mijn zeer gewaardeerde secretaresse, Heidi Bish, heeft met verve mijn agenda vrijge houden op de dagen dat ik aan dit proefschrift diende te werken. Haar dagelijkse steun en nauwgezetheid is van wezenlijk belang gebleken voor mijn functioneren.

Ruth Waisman heeft de Engelse tekst voor me verbeterd, Tonneke Popelier matakte dat de Nederlandse tekst goed leesbaar werd en dhr. De Haan van de Fryske Akademy vertaalde de samenvating in goed Fries.

De patienten en hun ouders, zonder wie dit onderzoek nooil had kunnen plaatsvinden. Hun trouw an het onderzoek, als weer eens om hun medewerking werd gevrangd, is bewonderenswaardig. Ook de "gezonde" kinderen die hebben meegewerk aan het psychologisch onderzoek verdienen allen lof.

De medische studenten van de Rijksuniversiteit Limburg die hun wetenschapsstage aan het buikpijnonderzoek hebben gewijd, leverden een belangrijke bijdrage an het onderzoek. Hopelijk hebben zij er net zo van genoten als ik.

De rol van de echtgenote achter de promovendus kan niet genoeg worden opgehemeld en is amper in woorden uit te drukken. Liefste Hyke, je hebt er geen idee van hoe belangrijk het voor me is geweest dat jij naast me stond en stat. Jerta, Hedser, Anke en Hyke, eindelijk heeft Heit al "die mislukte artikelen" tot een boekje samengevoegd. De stroom tekenpapier zal er niet minder door worden, denk ik. 


\section{CONTENTS}

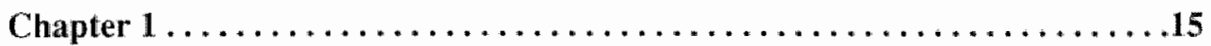

\section{Introduction}

1.1. Description of the Problem ..........................

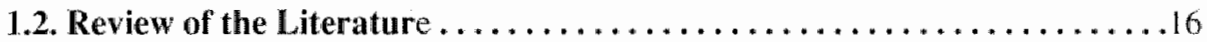

1.2.1. Somatic Aspects of Recurrent Abdominal Pain ................ 18

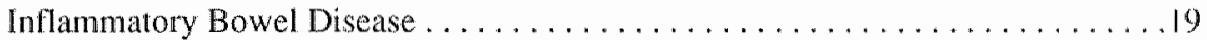

Food Hypersensitivity . . . . . . . . . . . . . . . . . . . . . . . . . . . . . 19

Lactose Intolerance . . . . . . . . . . . . . . . . . . . . . . . . . . . . . 19

Helicobacter pylori Infections . . . . . . . . . . . . . . . . . . . . . 20

1.2.2. (Dysi) Functional Aspects of Recurrent Abdominal Pain. . . . . . . . . .20

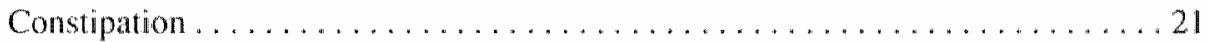

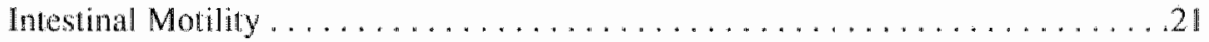

Irritable Bowel Syndrome . . . . . . . . . . . . . . . . . . . . . 22

1.2.3. Psychological Aspects of Recurrent Abdominal Pain . . . . . . . . . . 22

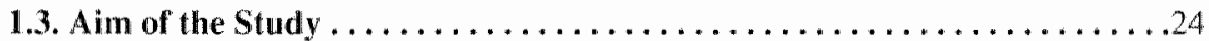

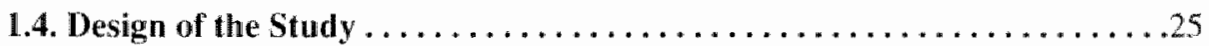

Inclusion Criteria . . . . . . . . . . . . . . . . . . . . . . . . . . 25

The Children. . . . . . . . . . . . . . . . . . . . . . . . . . . . . . . . 26

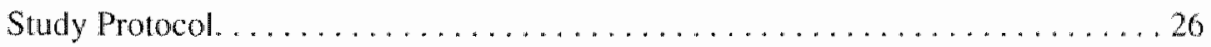

1.5. References ...................................... 28 


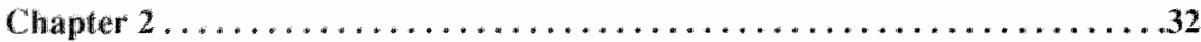

Psychological Findings in Recurrent Abdominal Pain

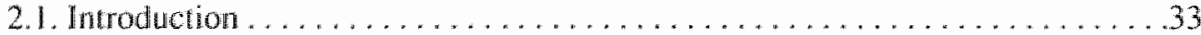

2.2. Patients and Methods . . . . . . . . . . . . . . . . . . . . . . 34

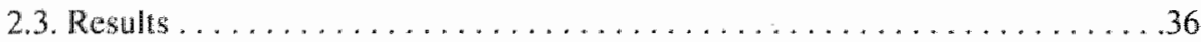

2.4. Discussion . . . . . . . . . . . . . . . . . . . . . . . . . . 40

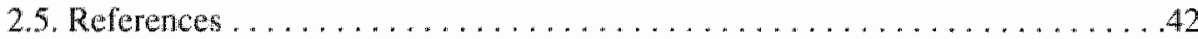

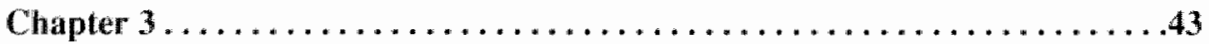

\section{Small Bowel Permeability to ${ }^{51} \mathrm{Cr}-$ EDT A in}

Recurrent Abdominal Pain

3.1. Introduction . . . . . . . . . . . . . . . . . . . . . . . . . . . . 44

3.2. Patients and Methods . . . . . . . . . . . . . . . . . . . . . . . . 44

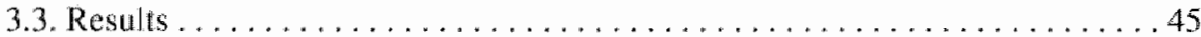

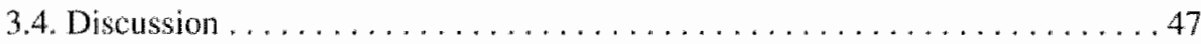

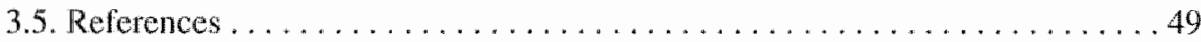

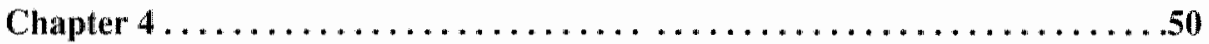

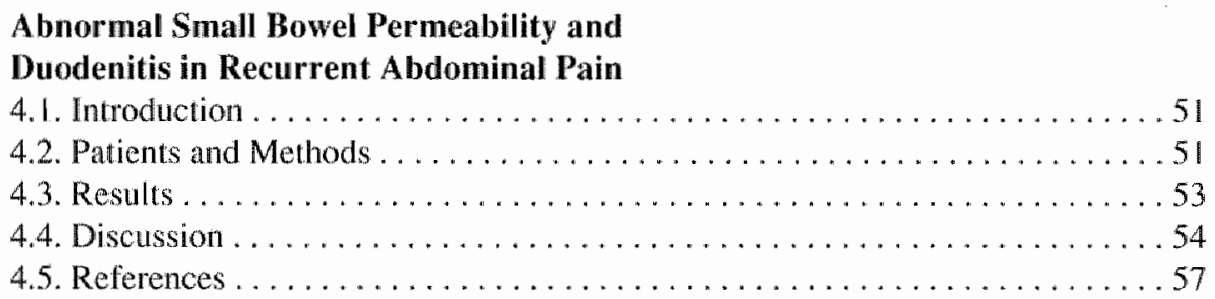

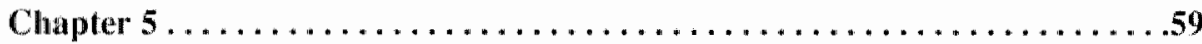

Gastroesophageal Reflux and Recurrent Abdominal Pain

5.1. Introduction . . . . . . . . . . . . . . . . . . . . . . . . . . . . . . . . . 60

5.2. Patients and Merhods. . . . . . . . . . . . . . . . . . . 60

5.3. Results ....................................61

5.4 . Discussiton . . . . . . . . . . . . . . . . . . . . . . . . . 64

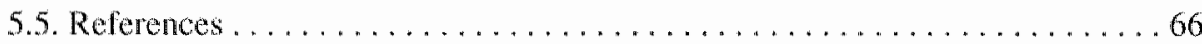

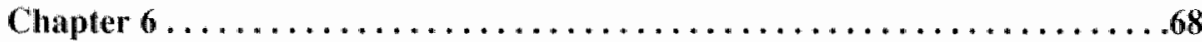

Helicobacter Pylori and Recurrent Abdominal Pain

6.1. Introdnction . . . . . . . . . . . . . . . . . . . . . . . 69

6.2. Patients and Methods . . . . . . . . . . . . . . . . . . . . . . 69

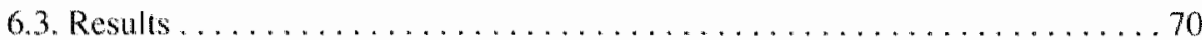

6.4 . Discussion . . . . . . . . . . . . . . . . . . . . . . . . . . 72

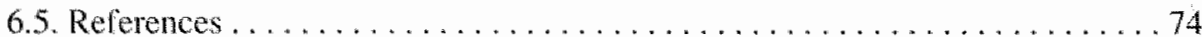




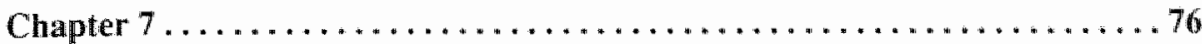

Diagnostic Value of Ultrasound in

Recurrent Abdominal Pain

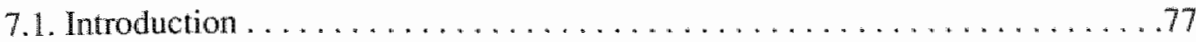

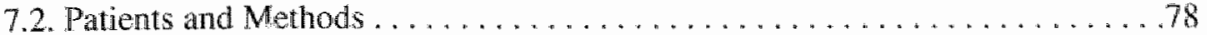

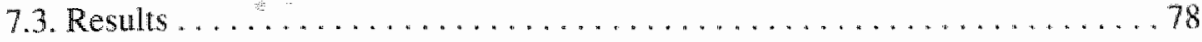

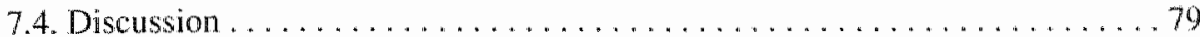

7.5. References .................................. 80

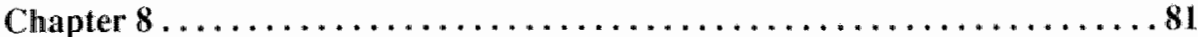

Diagnostic Contribution of Routine Laboratory

Investigations in Recurrent Abdominal Pain

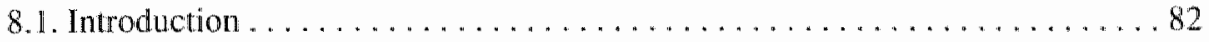

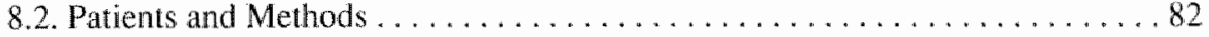

8.3. Results . . . . . . . . . . . . . . . . . . . . . . . . 83

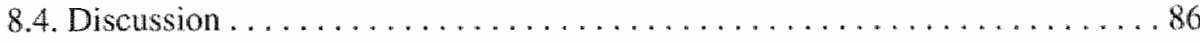

8.5. References ....................................90

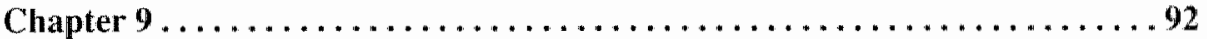

Summary and Conclusions

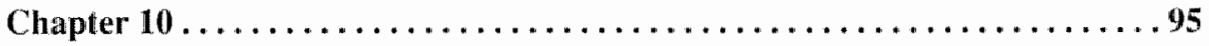

Epilogue

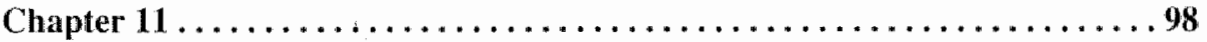

Samenvatting en Conclusies

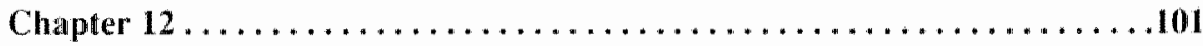

Gearfetting en Konklúzjes

Curriculum Vitae .....................................104 


\section{Introduction}

\subsection{Description of the Problem}

Paul, a nine year old boy, often complains of abdominal pain. Two or three times a week he comes home from school with a pale look on his face, lies down on the couch and cries. One or two hours later he is again playing and no longer seems to remember his recent complaints. For nine months now he has had recurrent bouts of abdominal pain. Sometimes he is free of pain for more than a week, but then the attacks can often persist longer than ten days. At times this is a reason for his staying away from school. His parents start wondering what to do about the complaints of their son. Should they lake Paul's abdominal pain seriously, and call their general practitioner or should they wait and see? When the complaints do not subside they eventually seek help. In most cases by consulting their general practitioner. The general practitioner is in turn confronted with the following questions: could this child have a serious problem; is there a need for a closer look by, for instance, a surgeon or a pediatrician or can he wait and see? Before referring the patient, the general practitioner should estimate the need for additional investigations by taking a short history and a physical examination looking for alarming symptoms and signs such as a palpable swelling or extreme pain at palpation. When these are not found, he reassures Paul and his parents. Medication such as spasmolytics could be prescribed in an attempt to ease the pain. In other cases further investigations will be carried out, depending upon his impression of the severity of the pain, his experience in dealing with the complaint and, last but not least, the persuasive attitude of the parents. A urinalysis and a white blood cell count with an ESR and sometimes a stool examination for parasites or occult blood loss is performed. When these investigations turn oul to be normal, it is thought most unlikely that the pain is of somatic origin. And yet something is bothering Paull. In many cases like Paul some minor problems at school or withirn the family, which could be the origin for this complaints, can be identified. But when adressing these problems, frequently no apparent improvement is noticed. Therefore, Paul and his parents return to their general practitioner. It may still take a lew months before it is decided that further investigation is necessary and that the need for a specialist consultation is evident.

Paul represents the kind of patient with Recurrent Abdominal Pain (RAP) that the pediatrician sees at the outpatient clinics. Often the specialist wonders how far he should 
subject patients such as Paul to funther investigations. Based upon his knowledge of recent literature, he assumes that there is only a small chance that a somatic etiology could be responsible for the abdominal pain, but this possibility camot be overlooked. Mostly, the above mentioned tests are repeated and some others, such as liver- and kidney function tests, radiological investigations such as a plain $X$-ray of the abdomen, are added. There is no common approach to this frequent found problem in school age children, and yet it is responsible for substantial medical consultation. The question is how far to go in the search for a correct diagnosis without the certainty that one can be found. The general medical opinion is that in the majoity of cases no clear cut somatic diagnosis can be made. This may either lead to an underestimation of the problem or to an excessive use of investigation on the child. More laboratory investigations do not always lead to a higher percentage of somatic duagnoses in these patients. Moreover, psychological investigations of children with RAP and their families often result in contradictory findings.

Patll's story illustrates the problems and dilemmas doctors are confronted with, when seeing children with RAP. The RAP syndrome is a clinically defined symptomatology complex and, therefore, represents a heterogeneous group of abnomalities. It cannot be diagnosed by the invariable presence of a single or a typical combination of abnormal laboratory tests, not can it be seen as one clinical entity. The pain may originate in the gastroimestinal system or other organ systems. Children often project abnormalities from other organ systems on to their abdomen. Therefore, the need for a good definition of the syndrome is mandatory. And yet, because of the above mentioned reasons, a simple definition of the RAP syndrome is difficult to formulate. Finally, the importance of the different somatic abnommalities thought to be responsible for the complaints, needs to be evaluated. Up to now, RAP has generally been considered a predominantly psychosonatic or functional disorder.

A review of the literature on RAP of the last 30 years will give more detailed information on the issues discussed here.

\subsection{Review of the Literature}

The first important contribution to the problem of Recurrent Abdominal Pain in chitdren was made by Apley and co-workers. In 1958 they published a lield survey of 1000 schoolchildren from Bristol, England (1). The children they studied met the following criteria: the child had had at least three bouts of pain, severe enough to affect his activities, over a minimum period of three months. Of the total study group, $10.8 \%$ had recurrent abdominal pains. Girls were affected more often than boys (12.3\% and $9.5 \%$, respectively). The incidence was highest between 5 and 10 years of age. However, from the age of 8 there appeared to be a striking rise in incidence in girls. Apley postulated that the onset of puberty might contribute to the pains. Two-third of the children felt the pain at or round the umbilicus. In $25 \%$ of cases the pain was severe. There was a great variability in time of occurtence, duration and frequency of the pain complaints. Many factors attributed to the pains, like excitement and wory were often associated with school. In many cases there were associated disturbances, like pallor (38\%), vomiting $(22 \%)$, tever $(11 \%)$ and headache $(23 \%)$. In $26 \%$ there appeared to be subsequent sleepiness or lethargy. In taking the family history, a significantly higher percentage of complaints was found by Apley in the other family members (mothers, fathers and 
siblings): he observed a higher frequency of recurrent abdomingl pains (46\%), peptic ulcers $(10 \%)$ and migraine $(14 \%)$, compared to controls. He stated that these figures wer almost certainly underestimated.

The children with RAP also expressed more emotional disturbances, such as fears, more noctumal enuresis, sleeping disorders and lack of appetite. Their personality traits tended to be "highly-strung, fussy, excitable, anxious, timid or apprehensive" compared to control children.

In order to look for somatic disease, EEG's were taken from 97 children with RAP and 202 children from the control group. In $4 \%$ of the RAP group focal spikes were seen, whereas in $10 \%$ of the RAP group the EEG was described as epileptiform. The same findings were described in $1.5 \%$ and $14.5 \%$ of the control children, respectively. Therefore, these epileptiform abnormalities lend no support to the hypothesis that RAP could be an expression of epillepsy without fits.

In later work Apley published the results of the so-called Hospital Series (2). The investigations carried out were: urinalysis, stool examination, blood examination (ESR, white blood cell count), radiological examinations (chest, barium meal with follow-up, pyelogram, cholecystogram), EEG. Not all the children underwent the total set of these investigations. They were selected and carried out depending upon presented complaints. In 8 out of 100 extensively investigated children with RAP, a somatic cause for the complaints was found. The abnormalities noticed were: vulvo-vaginitis, urethral cyst, hydronephrosis due to stricture of the ureter, recurrent renal infections, duodenal ulcer, Meckel's diverticulum, calcification of the pancreas and colon displacement (all 1. case each). In all these patients the abdominal pain disappeared after appropriate treatment.

The data Apley reported on emotional disturbances, personality traits and family history were all obtained by interpretation of questionnaires and interview results of both mother and child. School headmasters and headmistresses helped by providing reports on behavior, intelligence and achievements of both RAP and control group. No specific psychological tests were employed in investigating personality traits or family relations. Furthermore, the presence of stress factors was not investigated.

The search for somatic disease was restricted to the diagnostic possibilities at that time. Not all the patients underwent the same set of investigations, although Apley mentioned in a footnote that in a further 100 consecutive patients the percentage of accepted causative somatic disorders was the same.

With these studies, Apley set the trend for future thinking and research on RAP in childhood for many years, not only among pediatricians, but also among generall practitioners, psychologists and other workers-in-the-field.

As was mentioned in the above section, the etiology of this primarily clinically defined abnormality is heterogeneous. RAP patients can be divided into 3 groups:

1). A group of patients with a somatic disorder, probably causing the abdominal pain. 2). A group of patients with a (dys)functional disorder associated with abdominal pain. The complaints are not due to a disease, but to some dysfunction in the organism.

3). A group of patients in which psychogenic factors seem to predominate.

These different groups will be discussed in the following sections, together with the most important disorders related to them and the possible role they play in the etiology and pallhogenesis of RAP in childhood. 


\subsection{Somatic Aspects of RAP}

Many different somatic disorders can be held responsible for Recurrent attacks of Abdominal Pain. However, the majonty of these disorders ane rare and therefore probably not frequently involved in the etiology of RAP in children. Extensive investigations are often needed to exclude the presence of such somatic abnormalities. Unflortunately, a non-invasive screening investigation that could exclude the majority of these disorders, does not exist. The following table shows an overview of the most important somatic abnormalities associated with RAP in children. Most of these disorders are rare, and are diagnosed as a cause for RAP in only a minority of cases. Some of the most important or disputed somatic disorders associated with RAP will be discussed in more detail in the next paragraphs.

\section{Gastrointestinal Tract \\ (Jotermincwit) finwsusception \\ Duoderial Cysts \\ Mescinderial Custs \\ Omemam Cysis \\ Awhesions \\ Malrotation \\ Duplication \\ Recaprent Volvulus \\ Pepric Ulcer}

\section{Urogenital Tract}

Hydnoneforsis

Recurrent Urinary Infections

Renal Calculi

Renal Cysts

Renol Neoplasms

Adrenal Cysts And Thmors

Ovarian Cysis

Bholder Sromer

Reropenifoneal Cyists

\section{Inflammatory Bowel Disease*}

Crolw"s Disease

Wherative Colin

\section{Infectious Diseases* \\ Solnomerlla \\ Shigellig \\ Yensimia \\ Campylabacter Jomi \\ Helicabater Pylori}

\author{
Liver, Spleen, Pancreas \\ Hepatic Cysts \\ Hepatic "Tumors \\ Hepotic Abscess \\ Choledochal Cysts \\ Hydrops of the Callbladde" \\ Gall Bladder Stones \\ Pancrearic Cyos \\ Pancreatic Tumons \\ Pancrearic Calcifications \\ (Chronic) Pancrearitis: \\ (Massive) Splenomegaly
}

\section{Metabolic}

Cystic Fibrosis

Diabetes Mellinus:

porphyria

Organc acidurias

\section{Nutritional*}

Celiac Disease.

Lactose Intolerance

Food Hypersensinimiry

\section{Miscellaneous}

Mecke"s Diverticmlant

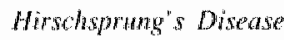

*These categories are discussed in more detail in the following pages.

\section{Table 1:}

Somatic abnormalities associated with Recurrent Abdominal Pain. 


\section{Inflammatory Bowel Disease}

Many diseases of the gastrointestinal tract can be responsible for recurrent abdonimal pains. Signs and symptoms are often unspecific. Inflammatory bowel disease, like Crohn's disease can cause recurrent bouts of abdominal pain. In a large number of patients many morths may go by between the appearance of the first symptom and the diagnosis. In patients with RAP inflammatory bowel disease is hardly ever ditgnosed (2, 3). The pain is frequently localized in the right lower quadrant and may appear as a vague, nonspecific discomfort.

Ulcerative colitis is more likely to appear with prominent bloody diarthea and more toxic symptoms. The definite diagnosis in this type of patient is mostly made before the abdominal pain becomes a prominent feature. These inflammatory bowel diseases of unknown etiology do not appear to be important in the differential diagnostic considerations on patients with RAP.

\section{Food Hypersensitivity}

Recently, food hypersensitivity has been reported to be a major factor in the etiology of the irritable bowel syndrome (IBS) $(4,5,6)$. In children, food hypersensitivity is thought to play at least some role in different disorders such as: Crohn's disease (7), ulcerative colitis (8), abdominal migraine (9), eczema (10) and the hyperkinetic syndrome (11). Apart from the abdominal pain in children with so-called abdominal migraine, some authors mention the presence of abdominal pain as a gastrointestinal manilestation of food hypersensitivity in children. At present, the role of food hypersensitivity in RAP, has not been firmly established, but it does seem likely to play a role in some children with RAP $(12,13)$.

\section{Lactose Intolerance}

As early as 1971, Bayless and Huang (14) reported on 5 children with episodes of abdominal pain, who experienced the same symptoms during an oral lactose tolerance test and became asymptomatic on a low milk products diet. The authors concluded that the abdominal pain was related to milk, and more precisely to lactose intolerance, suggesting therefore that lactose intolerance should be considered as an etiological factor in children with recurrent, otherwise unexplained abdominal pain.

In 1979 Barr et al reported on a study of 80 schoolchildren with RAP (15). Using the lactose breath hydrogen test (16), they detected lactose malabsorption in $40 \%$ of the children studied. Subsequently, the children were treated with a lactose-poor diet. When put back on their previous lactose-containing diet, the pain reappeared in $70 \%$ of the children.

In a similar study Liebman er al (17) found lactose intolerance in $29 \%$ of children with RAP. Dietary treatment was successful in reducing the pain in 10 out of 11 children. Both studies, however, were not blinded.

In 1981 Lebenthal (18) reported on a controlled study of 69 children with RAP. He did not find an increase in the prevalence of lactose intolerance in the RAP group. Furthermore, results of double-blind dietary treatment of lactose intolerant patients was not significantly different from that of lactose tolerant children. After a 12 month milk 
elimination diet, 6 of $15(40 \%)$ lactose malabsorbers and 5 of $13(38 \%)$ absorbers were free of pain. The elimination of lactose had no effect on the eventual outcome of RAP in einer absorbers or malabsorbers. The author concluded that lactose intolerance and RAP are two different entities.

In 1982 Wald ef al (19) described 40 children with RAP, who were investigated for the jresence of lactose malabsorption by means of a lactose breath hydrogen test. Although 12 children (30\%) were malabsorbers, improvement of abdominal pain complaints during lactose elimination was not significantly different from that of lactose absorbers. The authors concluded that lactose malabsorption is of little impontance in children with RAP.

Finally, in 1988 a study by Ceriani and co-workers (20) reported that in a group of 32 children with RAP, lactose malabsontion was detected in $75 \%$ of cases by means of a lactose breath hydrogen test. Out of 18 malabsorbers, 14 improved and reported lower pain frequency on a lactose-free diet. Reintroduction of lactose into the diet in amounts not exceeding the absorption capacity of each mallabsorber who had improved caused no relapse in any of the 14 patients. The authors concluded that lactose seems to play an important role in RAP in Italian children. However, the study group was small, the diet was not blinded, and the investigators did not make use of a control group.

In conclusion: at present the significance of lactose intolerance as a cause for RAP is still open to discussion. In a centain percentage of RAP patients it does play a role, but the high percentages mentioned in the early studies seem to be overestimated.

\section{Helicobacter pylori Infection}

Recently, there have been reports on the presence of Helicobacter Pylori infections of the antral mucosa in adults with gastritis, peptic ulcer disease and non-ulcer dyspepsia (2I, 22, 23). Subsequently, the presence of Helicobacter Pylori was reported in children with duodenitis, peptic ulcer disease and gastritis $(24,25,26)$. In the studies reported so far, there has been no report focusing only on the role of Helicobacter Pylori in children with RAP. Almost all the above mentioned studies concerned children with RAP as part of their study groups and reported the presence of Helicobacter pylori in up to $60 \%$ of these patients $(27,28,29)$. However, these were all selected patients, referred to specialized gastroenterology units. Furthermore, the clinical presentation of the patients remained unclear from the reports published. Consequenly, the children described as having RAP were part of a heterogeneous, ill-defined group of patients. Nevertheless, it is conceivable that in a certain percentage of these patients, Helicobacter pylori played a role in the atiology of the complaints (30).

\subsection{2. (Dys)Functional Aspects of RAP}

The second group of RAP patients consists of children with neither a somatic nor a psychogenic explanation for their complaints. They appear to suffer from some kind of dysfunctional disorder such as constipation or abnormal intestinal motility. In the following section these disorders will be discussed in more detail, including the imitable bowel syndrome, a dysfunctional disorder frequently encountered in adults, which shows many similarities with the RAP syndrome in children. 


\section{Constipation}

Chronic constipation may lead to abdominal pain. Although Apley did not negard this as an important cause for RAP (1), other athors found it one of the most frequently encountered somatic predispositions (31), or mention it as a possibility (32).

Barr et al (33) shoved that many children are constipated without being aware of tit. The diagnosis could easily be missed, since in taking the history of the child"s bowel habits this aspect is overlooked.

In an excellent overview on RAP in 1984, Levine and Rappaport (31) state that colonic distension could result in crampy abdominal pain.

Dimson (34) reported that 306 children with RAP were constipated at rectal examination in $22 \%$ of cases. Intestinal transit time, as measured by means of oral carmine, was prolonged in $44 \%$ of cases. The author suggested that constipation can account for RAP in some cases, but no percentage is mentioned. He further suggested that colonic spasms seemed to be the cause in the majority of cases and that children with RAP should be classified as having spastic colon.

Feldman et al (35) used supplementary dietary fiber and studied the effects on the abdominal pain in a double blind, placebo controlled manner. They found a $50 \%$ reduction in pain in $50 \%$ of the fiber treated group. However, $27 \%$ of the control group showed a simillar response.

In conclusion: constipation is present in a minority of children with RAP and is not considered to play an important role in the etiology. It probably represents a secondary phenomenon.

\section{Intestinal Motility}

Intestinal motility has been reponted to be abnomal in children with RAP. Kopel et al (36) showed that children with RAP have increased rectosigmoid motillity after parasympathetic stimulation with prostigmine. The authors suggested that children with RAP have a general autonomic imbalance.

Rubin et $a^{\prime}$ (37) and Apley et al (38) also studied the possibility of autonomic dysfunction in children with RAP. Symptoms were more likely to develop, and to be severe and intractable, if there was an underfying autonomic dysfunction (38).

Adults with unexplained abdominal pain, diagnosed as the irritable bowel syndrome, have altered modility of the small intestine (39).

In a study among children with RAP by means of rectal manometry in 1979 , Kline at al (40) reported that children with RAP showed more retaxation of their intemal sphincter than controls. These findings were thought to be consistent with an abnomal autonomic reactivity and might represent the predisposition to develop functional bowel symptoms in children with RAP.

Abnomal gastroduodenal motility was recently reported as a possible cause for RAP in children and adolescents (41). Gastroduodenal motility was studied during fasting with an intraduodenal recording probe. Patients with RAP showed slower propagation velocities and high-pressure duodenal contractions that were associated with abdominal pain. High-pressure contractions might stimulate proprioceptors along the intestinal wall which are perceived as pain by the patient. Therefore, the authors suggested that the altered intestinal motility may be the underlying mechanism for RAP in some children. However, as far as autonomic dysfunction is concerned, Feuerstein et al (42) studied the 
poteritial biobehivioral mechanisms of RAP in children by means of a cold pressor stimulus (puttung their hand into icc-cold water) during which several reponses were reconded. Autonomic, somatic, subjective and behavioral responses were recorded in a group of 10 RAP children and 19 matched control children. At all levels of recording the stimulus resulted into significant arousal. However, no significant differential response across the 2 groups was noted for any measure and no recovery deficit in autonomic arousal was demonstrated in any of these groups. These results did not support the assumption of a different response to stress in children with RAP nor did they show any evidence for autonomic instability.

A double-blind, placebo controlled study on the effectiveness of the promkinetic drug Cisapride (Prepulsid(B)) in reducing pain complaints in children with RAP failed to show at difference between the RAP group and a matched control group (Forget personal communication).

In conclusion: abnomal intestinal motility seems to be present in some children with RAP. Whether this abnomal motility can cause RAP in children, or should be regarded as a secondary phenomenon, needs further investigation.

\section{Irritable Bowel Syndrome}

The irritable bowel syndrome (IBS) in adults, is a well-known cause of longlasting, mostly unexplained, abdominal pain. The symptomatology resembles the clinical picture of RAP in children (43). In their survey on 120 children with RAP, Stone and Barbero (3) suggested that the abdominal manifestations of this group of patients could be described as the Irritable Bowel Syndrome in Childhood. As in RAP, many possible explanations have been thought to be responsible for the complaints. Psychosocial factors were reported to play a role in the pathogenesis of IBS (44). Psychological assessment showed that patients with IBS reported more stress and exhibited more psychopathology. However, the role of these psychosocial factors in the disonder is controversial. Some accept these observations as secondary to chronic illness, the main feature of the disorder being biological: disturbances in gut motility (45). Others consider psychopathology to be the primary feature (46). Whereas yet others find it hard to believe that the complaints are exclusively biological or psychiatrical (47). The motility disturbances reported to be associated with the IBS are an increase in the colonic activity in constipated patients and a decrease in activity during diarthea (48). Additionally, a contelation was found between pain and increased rectosigmoid muscle contraction (49). Furthemore, an increased motility of the colon was observed during periods of stress (50). These observations show a great similarity to the findings in the RAP syndrome in childhood. In his follow-up study, Apley showed that about 33\% of children with RAP continued to hawe abdominal pain, $33 \%$ were free of abdominal pain but had other pain complaints, and the remaining $33 \%$ were free of all complaints (51). These figures might imply that the child with RAP conld become an adult with IBS.

\subsubsection{Psychological Aspects of RAP}

The search for psychological factors in the RAP syndrome has been extensive. Apley (1, 2) reported that children with RAP, compared to controls, tended to show characteristic personality traits. Expressions of emotional disturbance were considerably commoner, 
and a combination of these was usually evident in the child. Precipitating hows for the pain were found in one-third of the children. In gahering his data, he madte use of observations and interviews with detailed questionnaires, but no specific psychological tests were perfomed. On the basis of these findings, and the lack of evidence for somatic disease in his patient group, he tended to regard the RAP syndrome as a psychosonatic disease. He claimed that in the large majonity of RAP patients the family and personal history would provide positive evidence of an emotional disorder, and that with "informal psychotherapy", the pains would usually disappear or be relieved. These studies by Apley and co-workers have determined the attitude of many health-care workers, family doctors and pediatricians in subsequent years. The RAP syndrome was generally accepted as a psychosomatic disorder $(52,53,54)$, and based on this assumption, therapeutic measures were directed at solving emotional disturbances, stress-factors, family conflicts, problems at school etc.(55). A supportive psychotherapeutic approach, consisting of explaining and reassuring, was the most frequently recommended treatment $(2,32,51,56-58)$. Although it could not be claimed that this approach "cured" the pains, it was helpful in speeding the recovery from attacks of pain and lessening the occurrence of other symptoms, both physical and psychological. Patients were more able to adapt and lead a nomal live (51).

Astrada ef al (59) sudied 22 children with RAP in their psychiatric consultation service. They found several disorders according to the Diagnostic and Statistical Manual of Mental Disorders III (DSM-III) (60) among their patients. There appeared to be an association between age, sex and diagnosis. Chilldren with anxiety disorders were younger, while children with psychogenic pain and conversion disorders tended to be older, and mainly girls. The study involved only a small number of patients, but the authors suggested that it might help clinicians to anticipate the most likely DSM-III diagnosis associated with RAP. However, from the description of the patient group it seems questionable that they studied the kind of patients that are usually regarded as RAP patients. Thirteen of them were older than 12 years and some were studied while having their first series of attacks of pain.

In a study on children hospitalized because of abdominal pain of unknown origin Hughes $(61,62)$ found 23 children that met the DSM-III criteria for childhood depression. Unfortunately he did not have a control group, and the way his data were collected was not uniform in all children.

However, in a controlled study by Hodges et al (63) using the Childrens" Depression Inventory (64) and a psychiatric interview, RAP patients did not report more depression than healihy control children. In contrast, RAP patients' mothers showed significanily more depression than the healthy control group ones. The authors stated that some depressed children may present abdominal pain, but that RAP children should not automatically be assumed as being depressed.

In studying the same group for the presence of anxiety disorders they reported highes levels of anxiety in RAP children and their parents compared to controls (65). However, in a substantial number of RAP children no apparent anxiefy disorder was found. The authors suggested a possible causal relationship between the presence of anxiefy and autonomic dysfunction leading to gastrointestinal reaction and consequently abdominal pain in predisposed patients. Further details of these aspects were discussed in the preceding section on intestinal motility.

Clinicians as well as parents often assume that when no somatic disorder can be found, the abdominal pain has to be psychogenic in origin (66). However "most of the studies 
on psychosocial factors in RAP lack an informative control group and are often based upon clinical observations rather than objective measurements with reliable tests. Furthermore, the selection of patients is often unclear and not always uniform. The increasing attention towards the psychosocial, amotional and family factors in RAP in childhood led to more detailed, controlled studies which have shown quite different findings to those described in the above section. In a study of 30 RAP children and 30 pain free controls, MoChth ef al (67) falled to show any statistical significant differences between the groups on a variety of psychologicall variables thought to be associated with psychogenic factors. Every child in the RAP group matched Apley's criteria (1), and adlitional investigations did not show a somatic cause for their complaints. The children and their parents were interviewed, underwent personality tests and were investigated for the presence of stress factors or depression. The authors stated that several factors, like selection bias or too low sensitivity of the tests, may have led to their failure to find differences. They concluded, however, that these findings do not support the widespread assumption that RAP, for which no medical cause can be found, is psychogenic.

Subsequently, in a study of 44 children with abdominal pain of somatic origin, 16 children with non-somatic abdominal pain and 30 pain-free controls, Raymer et al (68) found evidence of psychological problems in both pain groups. The somatic group consisted of 24 children with Crohn's disease and 20 with ulcerative collitis. The nonsomatic group had had RAP over a period of at least 6 months, which after extensive investigations could not be attributed to somatic disease. All children were investigated by means of a self-esteem inventory, a personal adjustment inventory, life events scores, at stimulus appraisal questionnaire and a depression inventory. Out of 12 variables, 9 showed no significant statistical difference. Patients with Crohn's disease showed low self-esteem and depression. Patients with ulcerative colitis showed more depression, whereas the non-somatic group showed low self-esteem. No differences were found between the somatic and non-somatic group as a whole. They also found a higher frequency of emotional problems and more severe distress among children with abdominal pain than among controls. Whether these differences were secondary to the underlying abdominal pain was not clear. The fact that no psychological differences between the somatic and non-somatic group were found, did not support the assumption that RAP is a psychosomatic disordent.

\subsection{Aim of the Study}

From the above sections on different somatic, (dys)functional or psychogenic disorders, it is clear that many questions regarding RAP in children still remain unanswered. The most important ones being those concerning etiology. Recent research seems to support the possibility of new, additionall somatic causes. But these new lindings provide an explanation for only a small percentage of the patients presented. As stated before, the RAP syndrome presents a heterogeneous clincal picture for which a precise diagnosis is hard to make. Consequently, the inclusion criteria in different studies on RAP patients were probably not uniform. For many years, Apley's work backed the idea that psychological factors were the major cause for RAP in children, hampering the studying of possible somatic causes. Since recent developments in the field of diagnostic possibilities have revealed additional somatic abnomalities associated with RAP, the percentage of somatic disorders in RAP is now probably higher than $10 \%$ and there still 
remains a large group of children without a specific diagnosis.

The aim of the present study was to investigate the presence of both somatio and psychological disturbances in a large, well-defined group of schoolichildinen with RAP, using recently developed sensitive diagnostic techniques in ombination with a thorough investigation of psychollogical factors that could be involved in the etiology of the RAP syndrome. In doing this we wanted to find out whether the present general attitude towards RAP needs to be changed and whether its' diagnostic approach should be reviewed.

\subsection{Design of the Study}

Based upon the controversies in the literature a prospective study was designed, taking both somatic and psychological aspects of the RAP syndrome into account. In order to assemble an as representative group of schoolchildren with RAP as possible, the schooldoctors of the Department of Child Health in the city of Maastricht were asked to collaborate in the study. During routine and scheduled general examinations of all schoolchildren at specific ages, the schooldoctors were to ask all parents and children if the children had suffered abdominal pain in the past 6 months. If so, children and parents were informed about the study, and after giving their consent, refented by their general practitioner to the outpatient clinics of the Pediatric Department at the Academic Hospital Maastricht. Furthermore, all family doctors in the region of Maastricht were informed of this study through their local association by an information leaflet. In this manner we expected to assemble a representative percentage of the population of children with RAP in our region. All patients were seen by the same pediatrician (SvdM).

\section{Inclusion Criteria}

The inclusion criteria laid down at the beginning of the study were as follows:

1). Age range: 5.5 to 12 years.

This age range was chosen because in The Netherlands all children are seen by a schooldoctor at the age of 5.5 years. In this way we expected to see more of the younger age-group. The upper age-range was chosen so as to restrict our study to primary schoolchildren.

2). Recurrent abdominal pain of unknown origin lasting for no less than 6 months.

In contrast to the criteria laid down by Apley (1), who chose a period of 3 months as the minimum duration of the complaints, we chose a period of six months. Our own clinical experience had shown that many children suffer from abdominal pain, but that a large percentage of these children cease to have complaints within 3 to 6 months. By choosing a period of six months we expected to select the real chronic pain patients as opposed to an otherwise too "nomal" group of schoolchildren.

3). Attacks of pain varying in severity, duration and frequency.

4). Sometimes accompanied by vegetative symptoms such as paleness, nausea and vomiting.

These two latter criteriat were added as an aid in describing the clinical picture of the RAP patient, facilitating his identification. 


\section{The Children}

The total number of patients required was set at 100. The first patient entered the study in 1985. The last patient entered the study in 1989. We then had a total of 106 patients. The patient group then consisted of 38 boys and 68 girls $(1: 1.8)$, ranging in age from 5.5 to 14 years (one girt of 14 , still attending primary school), mean age 8.74 years. The mean duration of the abdominal pain on the first visit to the outpatient clinics was 23.1 months with a range of 6 to 120 months. The peak-age at which the complaints started was 6 years (18.8\% of the patients). The mean frequency of attacks of abdominal pain was 4 times per week ranging from once a month to every dlay. The mean duration of the attacks was 5.8 hours ranging from 5 minutes to all day. The localization of the pain was pertumbilical in $41.6 \%$ of cases. Associated symptoms consisted of nausea (38.6\%), vomiting $(30.7 \%)$, anorexia $(34.7 \%)$, paleness $(31.7 \%)$ and headaches $(17.8 \%)$.

\begin{tabular}{ll}
\hline Number of Patients & 106 \\
Sex (male/female) & $38 / 68$ \\
Age in years (mean, range) & $8.74(5.5-14)$ \\
Duration of Complaints in months (mean, range) & $23.1(6-120)$ \\
Age Peak at Start of Complaints (years) & 6 \\
Frequency of Attacks in times/week (mean, range) & $4(1 /$ month - every day) \\
Duration of the Attacks in hours (mean, range) & $5.8(5 \mathrm{~min}$ - all day) \\
Associated Symptoms (\% present) & \\
Nausea & $39 \%$ \\
Vomiting & $31 \%$ \\
Anorexia & $35 \%$ \\
Paleness & $32 \%$ \\
Headaches & $18 \%$
\end{tabular}

\section{Table 2:}

Biographical and clinical characteristics of the Study Group

\section{Study Protocol}

All children followed the same protocol, which consisted of the following:

- a thorough physical examination

Additional laboratory examinations:

- Haemarology:

haemoglobin, haematocrit, ESR, leucocyte count and differentiation.

- Clinical Chemistry:

liver- and kidney function tests, total protein with ellectrophoresis, total $\operatorname{IgE}$ with specific allergens (inhalation- and food-allergens).

- Urime:

protein, glucose, urinary sediment. 


\section{- Stools:}

Ova, parasites, occult blood loss (3 times).

- Nuclea Medicine:

A small bowel penneability test, making use of shromium Labelled ethylenediaminetetracetate ("Cr-EDTA) as a marker. By using a "Cr-EDTA permeability test we expected to find signs of duodenal damage in children with RAP, pointing to the presence of an intestinal origin of these patients" complaints.

- Radiology:

An Ultrasound examination of the upper- and lower abdomen was performed by a standard procedure.

\section{- A Lactose breath hydrogen test:}

An oral lactose load of $2 \mathrm{gr} / \mathrm{kg}$, with a maximum of $50 \mathrm{gr}$. Breath samples were analysed using a Lactoscreen (BoekLoos). Values were considered abnormal when exceeding $20 \mathrm{ppm}$. As there was still considerable debate about the role of lactose intolerance in RAP, we added the lactose breath hydrogen test to the protocol, in onder to investigate the prevalence of lactose intolerance in our patient group and to estimate the clinical importance of lactose intolerance in RAP.

- Psychological tests and interview:

All children were seen by the same psychologist (AG), who perfomed a variety of psychological tests and interviewed both parents and children. We based our psychological measurements primarily on Apley"s (1) findings regarding personality traits, family influences, signs of stress and emotional distress. Furthermore, we took into account McGrath's (57) recommendation for the need of a matched control group and the use of objective, valid instruments. Therefore, we performed the same psychological tests and the interview on a matched control group of schoolchildren.

Additionally, part of the patienis underwent endoscopy, duodenal biopsy and a 24 hour intraesophageal pH-monitoring. However, the latter two investigations were not part of the standard protocol.

Finally, a large percentage of the study group was investigated for the presence of serum antibodies to Helicobacter pylori.

This study design mesulted in the investigation of a broad variety of aspects of RAP in schoolchildren. The following chapters all deal with one of these aspects. The role and meaning of gastroenterological and psychological factors are the hallmark of this study on RAP. Chapter 2 concems the psychological and family factors that were extensively investigated in order to judge whether their, at present still estimated as important, role in the etiology of RAP is justified. Evidence for an enteral origin of the abdominal pain is described in chapter 3 on abnormal small bowel permeability, and chapter 4 which concems the association between this abnomal permeability and duodenitis in children with RAP. In chapter 5 gastroesophageal reflux as a possible somatic cause is presented and discussed, whereas the prevalence of serum antibodies to Helicobactier pylori, generally thought of as a possible new important cause for RAP is reported in chapter 6. Our diagnostic approach towards RAP is described in the chapters 7 and 8 , conceming the diagnostic value of ultrasound and "routine" laboratory investigations in the diagnostic approach of RAP. Finally, we present a flow-diagram proposing a possible approach towards RAP in future. 


\subsection{References}

(1): Apley J and Nalsh N. Recurrent Abdominal Pains: A field survey of 1000 schoolchildren. Arch Dis Child 1958; 33: 165-170

(2): Apley J.The Child with Abdominal Pains. London. Blackwell Scientific Publications, 1959, 2nd edition 1975

(3): Stone RJ, Babbero G. Recurrent abdominal pain in childhood. Pediatrics 1970; 45: $732-738$

(4): Petitpienc M, Gumowski P and Girard JP. Imitable bowel syndrome and hypersensitivity to food. Ann Allergy 1985; $54: 538$ - 540 .

(5): Alun Jones $\mathrm{V}$, Shorthouse $\mathrm{M}, \mathrm{McL}$ atughlan $\mathrm{P}$, et al. Food intolerance: a major factor in the pathogenesis of irritable bowel syndrome. Lancet 1982; 2: $1115-1117$.

(6): Nanda R, James $\mathrm{R}$, Smith $\mathrm{H}_{4}$ Dudley CRK and Jewell DP. Food intolerance and the irritable bowel syndrome. Gut 1989; 30: 1099- 1104 .

(7): O'Morain C, Segal AM, Levi AJ and Valman HB. Elemental diet in acule Crohn's disease. Arch Dis Child 1983; 58: 44-47.

(8): Truelove SC. Ulcentive colitis provoked by milk. Br Med J 1961; 1: 154-160.

(9): Bentley D, Katchburian A and Brostoff J. Abdominal migraine and food sensitivity in children. Clin Allergy 1984; 14: 499-500.

(10): Atherton DJ. Skin disorders and food allergy. J Roy Soc Med 1985; suppl. 5, 78: $7-10$.

(11): Egger J, Graham PJ, Carter CM, Gumley D and Soothill JF. Controlled mial of oligoantigenic treatment in the hyperkinetic syndrome. Lancet 1985: ii: 540-545.

(12): Dannaeus A, Johansson SGO, Foucard $\mathrm{T}$ and Öhman S. Clinical and immunological aspects of food allergy in childhood. Acta Paediatr Scand 1977; 66: 31-37.

(13): Crook WG. Recurrent abdominal pain (letter). Am. J Dis Child 1980; 134: 326-327.

(14): Bayless TM and Huang S-S. Recurrent abdominal pain due to milk and lactose intolerance in school-aged children. Pediatrics 1971; 47: 1029-1032.

(1.5): Barr RG, Levine MD and Watkins JB. Recument abdominal pain due to lactose intolerance. New Engl J Med 1979; 300: 1449-1452.

(16): Perman JA, Barr RG and Watkins JB. Sucrose malabsorption in children: Noninvasive diagnosis by interval breath hydrogen detemnination. I Pediatr 1978; 93: 17-22.

(17): Liebman WM. Recutrent abdominal pain in children: Lactose and sucrose intolerance, a prospective study. Pediatrics $1979 ; 64: 43-45$.

(18): Lebenthal E, Rossi TM, Nord KS and Branski D. Recurent abdominal pain and lactose absorption in children. Pediatrics 1981; 67: 828-832.

(19): Wald A. Chandra R, Fisher SE, Gartner JC and Zitelli B. Lactose malabsorption in recurrent abdominat pain of childhood. I Pediatr 1982; 100: 65-68.

(20): Ceriani R, Zuccato E, Fontana M, Zuin G, Fentri L, Principi N, Paccagnini S and Mussini E. Lactose malabsorption and recurrent abdominal pain in Italian children. $J$ Pediatr Gastroenterol Nutr 1988; 7: 852-857.

(21): Buck GE, Gourley WK, Lee WK, et al. Relation of Campylobacter pyloridis to gastritis and peptic ulcer. J Infect Dis 1986; 153: 664 - 669.

(22): Rauws EA, Langenberg W, Houthoff H, ef al. Campylobacter pylonidisassocianed chronic active antral gastritis. Gastroenterology 1988; 94: 33 - 40 . (23): Loffeld RJLF; Potters HVPJ, Arends JW, Stobberingh E, Flendrig JA and van Spreeuwel JP. Campylobacter associated gastritis in patients with non-ulcer dyspepsia. J Clin Pathol 1988; 41: $85-88$. 
(24): Drumm B, OBrien A, Cut E and Sheman P. Campylobacter pylondisassociated primary gastritis in children. Pediatrics 1987: 80: 192 - 195.

(25): Mahony MJ, Wyatt JI and Littlewood JM. Campylobacter pylori gastritis. Anch Dis Child 1988; 63: 654-655.

(26): Killbridge PM, Dahms BB, Czimn SJ. Campylobacter pylori-associated gastritis and peptic ulcer disease in children. Am J Dis Child 1988; 142: 1149 - 1152.

(27): Cadranel S, Glupczynsky $\mathrm{Y}$, Labbe $\mathrm{M}$ and de Prez C. Campylobacter pylon in children. In: Menge H, Gregor M, Tytgat GNJ and Marshall BJ (eds) Campylobacter pylori. Springer Verlag, Berlin, Heidelberg 1988: pp. $110-\| 15$.

(28): Oderda G, Vaira D, Holton J, Dowsett JF and Ansaldi N. Serum pepsinogen and $\operatorname{IgG}$ antibody to Campylobacter pylon in non-specitic abdominal pain in childhood. Gut 1989; 30: 912 - 916 .

(29): Drumm B, Sheman P, Cutz $\mathbb{E}$ and Karmali M. Association of Campylobacter pylori on the gastric mucosa with antral gastritis in children. $\mathrm{N}$ Engl J Med 1987; 316: $1557-1561$.

(30): Thomas JE, Eastham EJ, Elliott TSJ and Nelson R. Campylobacter pylori in children - a common cause of symptoms. Gut 1988; 29: A707.

(31): Levine MD, Rappaport LA. Recurrent abdominal pain in schoolchildren: The Joneliness of the long-distance physician. Pediatr Clin North Am 1984; 31: 969-991 (32): Dodge JA. Recurrent abdominal pain in children. Br Med J 1976; I: 385-387 (33): Barr RG, Wilkinson R, Levine MD and Mulvihill D. Chronic and occult stool retention. A clinical tool for its evaluation in school aged children. Clin Pedliatr 1979; 18: 674.

(34): Dimson SB. Transit rime related to clinical findings in children with recurrent abdominal pain. Pediatrics 1971; 47: 666-674.

(35): Feldman W, MoGrath PJ, Hodgson C, Ritter H and Shipman RT. The use of dietary fiber in the management of simple childhood idiopathic recurrent abdominal pain: Results in a prospective double blind randomized controlled trial. Am J Dis Child 1985; 139: $1216-1218$.

(36): Kopel FB, Kim IC and Barbero GJ. Comparison of rectiosigmoid motility in normal children, children with recurrent abdominal pain and children with whcerative colitis. Pediatrics 1967; 39: 539-545

(37): Rubin LS, Barbero GJ and Sibinga MS. Pupillary reactivity in children with recurrent abdominal pain. Psychosom Med 1967; 29: 111-120.

(38): Apley J, Haslam DR and Tulloh CG. Pupillary reactions in children with recument abdominal pain. Arch Dis Child 1970; 46: 337-340.

(39): Kumar D and Wingate DL. The irritable bowel syndrome: a paroxysmal motor disorder. Lancet 1985; 2: 973-977.

(40): Kline JJ, Hodges VK, Cameron BA and Barbero GJ. Rectal tonometry in recument abdominal pain of childhood (RAP). Am J Gastroenterol 1979; 72: 337.

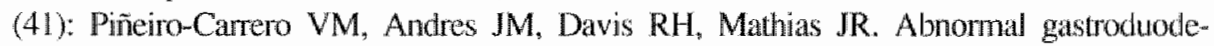
nal motility in children and adolescents with recurrent functional abdominall pain. $J$ Pediatr 1988; 113: 820-825.

(42): Feuerstein M, Barr RG, Francoeur TE, Houle $M$ and Rafman $S$. Potential biobehavional mechanisms of recurrent abdominal pain in children. Pain 1982; 13: 287 298.

(43): Dotevall G, Svedlund J, Ssjodin I. Symptoms in irritable bowel syndrome. Scand J Gastroenterol 1982; 17: suppl. 79: 16 - 19. 
(44): Palmer RL, Stonehill $\mathrm{E}_{\mathrm{i}}$ Crisp AH et al. Psychological characteristics of patients with the iritable bowel syndiome. Posterad Med 1974; 50. 416 - 419.

(45): Snape WJ, Carlson $\mathrm{CM}$ and Cohen $\mathrm{S}$. Colonic myoelelectric activity in the imitable bowel syndrome. Gastroenterology 1976; 70:326-330.

(46): Drossman DA, Sandler RS, McKee DC and Lovitz AJ. Bowel pattems among subjects not seeking heallh care. Use of a questionnaire to identify a population with bowel dysfunction. Gastroenterology 1982; 83:529-534.

(47): Latimer P, Sama S, Campbell D, Latimer M, Waterfall W and Daniel EE Colonic motor and myolectrical activity: A comparative study of normal subjects, psychoneurotic patients, and patients with the irritable bowel syndrome. Gastroenterology 1981; 80: $893-901$.

(48): Kumar $\mathrm{D}$ and Wingate DL. The irritable bowel syndrome: a paroxysomal motor disorder. Lancet 1985 ; i: 973 - 977.

(49): Moriarty $\mathrm{KJ}$ and Dawson AM. Functional abdominal pain: further evidence that whole gut is affected. Br Med J 1982; i: 1670 - 1672.

(50): Almy TP and Tulin M. Gastroenterology 1947; 8: $616-626$.

(51): Apley J, Hale B. Children with recurrent abdominal pain: How do they grow up ? Br. Med J 1973; 3: 7-9.

(52): Nicol AR. Psychogenic abdominal pain in childhood. $\mathrm{Br} \mathrm{J}$ Hosp Med 1982; 27 : $351-353$.

(53): Liebman WM. Recurrent abdominal pain in children: A retrospective study of 119 patients. Clin Pediatr 1978; 17: 149-1.53.

(54): Heinild S, Malver $\mathbb{E}$, Roelsgaard $G$ and Worning B. A psychosomatic approach to recurrent abdoninal pain in childhood. Acta Paediatr Scand 1959; 48: 361-370.

(55): Green M. Diagnosis and treatment: Psychogenic, recurrent, abdominal pain. Pediatrics $1967 ; 40 ; 84-89$.

(56): Jackson RH. Abdominal pain in childhood. Practitioner 1976; 217: 377-383

(57): Hammond JE. The periodic syndrome and migraine. Practitioner 1976; 217: 384389.

(58): Lebenthal E. Recurrent abdominal pain in childhood. Am J Dis Child 1980; 134: $347-348$.

(59): Astrada CA, Licamelle WL, Walsh TL and Kessler ES. Recument abdominal pain in children and associated DSM-III diagnoses. Am J Psychiatry 1981; 138: 687-688.

(60): American Psychiatric Association: Diagnostic and statistical manual of mental disorders (DSM III). Washington DC: American Psychiatric Association, 1981.

(61): Hughes $M$ and Zimin R. Children with psychogenic abdominal pain and their Tarvilies. Clin Pediatr 1978; 17: 569-573.

(62): Hughes MC. Recurrent abdominal pain and childhood depression: clinical observations of 23 cliildren and their families. Amer J Orthopsychiat 1984; 54: 146-155.

(63): Hodges K. Kline JJ, Barbero G and Flanery R. Depressive symptoms in children with recurrent abdominal pain and in their families. J Pediatr 1985; 107: 622-626.

(64): Kovacs M. Rating scales to assess depression in school-age children. Acta Paedopsychiatr 1980-81; 46: 305-315.

(65): Hodges $\mathrm{K}$, Kline $\boldsymbol{J}$, Barbero $\mathrm{G}$ and Woodruff $\mathrm{C}$. Anxiety in children with recurrent abdominal pain and their parents. Psychosomatics $1985 ; 26: 859-866$.

(66): Barr RG and Fenerstein M. Recurrent abdominal pain syndrome: How appropriate are our basic clinical assumptions? In: PJ MoGrath and P Firestone (Eds.), Pediatric and Adolescent Behawior Medicine: Issues in Treatment Springer, New York, pp. 13-27. 
(67): MoGrath PJ, Goodman IT, Firestone P, Shipman R and Peters S Recurrent abdominal pain: a psychogenic disorder ? Arch Dis Child 1983; 58: 888-890.

(68): Raymer D, Weininger $\mathrm{O}$ and Hamilton JR. Psychological problems in children with abdominal pain. Lancet 1984; i: 439440. 


\title{
Psychological Findings in Recurrent Abdominal Pain
}

\author{
S.B. van der Meer, A. Ghys, P.P. Forget, R.H. Kuijten, J.W. Arends
}

\section{Summary}

In order to investigate the possible role of psychological factors in Recurrent Abdominal Pain, 51 patients aged between 9 and 12 years (study group) were interviewed and psychologically examined. Of these patients, 30 had no definite diagnosis (fimctional group), and 21 had a possible somatic efiology (somatic group). Psychologicall tests and interview results were compared to those of a matched group of 86 schoolchildren (control group). The majority of psychological factors tested, particularly those referring to personality traits showed no significant difference between study group and control group. Pain complaints in the children's fathers, stress-factors and signs of emotional distress were more frequent in the study group. We conclude that there appear to be no essential psychological differences in children with Recurrent Abdominal Pain and control children. The differences found are not sufficient to explain the origin of Recurrent Abdominal Pain in children.

(Submitted for publication) 


\subsection{Introduction}

Abdominal pain is a common problem in children. Various studies have shown that at least $10 \%$ of school-aged children regularly complain of abdominal pain $(1,2)$. Although a common disorder, little is known about the etiology, course and prognosis. Traditionally, patients are subdivided into two groups: organic or somatic and psychogenic or functional. The organic group consists of patients with a specific diagnosis, like Crohns" disease, hydronefrosis, gallbladder disease etc. Originally, the organic group was considered to be small, as shown in a large study performed amongst schoolchildren in 1958 by Apley (3), who found organic causes for the complaints in no more than $10 \%$ of these children. In later years, additional possible organic explanations for the abdominal pain such as lactose intolerance (4), abnormal gastroduodenal motility (5) and inflammatory bowel disease (chapter 4) (6) were suggested. At present, therefore, the frequently cited figure of $10 \%$ organic disease is open to discussion. It seems likely. that with improved diagnostic methods the percentage of Recurrent Abdominal Pain (RAP) patients in which some underlying organic disease can be detected will increase, reducing the relative contribution of psychogenic factors.

The psychogenic or functional group consists of patients with no known organic disease, so far, whose pain is assumed to be due to environmental and psychosocial stress factors $(7,8)$. When compared to controls, Apley reported positive evidence for emotional disturbance in his group of patients. However, whether these phenomena were causally related remained uncertain (3). Nevertheless, he claimed, that in cases where organic disease was ruled out, "informal psychotherapy", consisting of reassuring and explanation, could be of help in deconditioning the leamed abdominal pain. But when comparing 30 untreated patients with 30 patients treated with this therapy, no difference appeared in the number of patients that were free of abdlominal pain and the number of patients that continued to have abdominall pain (9). Furthermore, the data Apley reported on emotional disturbance, personality traits and family history were all obtained only by interpretation of questionnaires and interview results of mother and child. School headmasters and headmistresses helped by providing reports on behavior, intelligence and achievements of both the RAP and the control group. No specific psychological tests were employed in investigating personality traits or family relations. And linally, the presence of stress factors was not investigated.

Using more reliable and valid measurements, McGrath et al (10) reported on a controlled study, that failed to show significant differences between a group of 30 children with RAP and a group of 30 pain-free children, on a variety of psychosocial variables such as stress factors, personality traits and family pain history. These RAP patients were all referred to a special gastroenterology service, which could mean that some selection had taken place. Furthermore, the control group was taken from children attending other outpatient clinics, which certainly means a selection. A study by Raymer et al (11) amongst 44 children with organic abdominal pain (Crohn's disease and ulcerative colitis) and 16 with non-organic abdominal pain did show signs of psychological distress in both groups, compared to controls. However, there were no differences on psychological grounds between the organic and non-organic group. The group of RAP patients in this study was rather small and had been referred to a special gastroenterology division, which might have influenced the kind of patients that were investigated. For the above mentioned reasons, it would appear that there still is considerable debate on the role and meaning of psychosocial factors in children with RAP. Therefore, the purpose 
of our study was to investigalle the prevalence of organic disease in a group of schoolaged children with RAP on the one hand, and the relationship between psychosocial variables and RAP on the other. In this paper we show the results of the psychological tests and interviews we performed on both our patients with RAP and a matched control group.

\subsection{Patients and Methods}

We conducted a prospective study on RAP, in the south of The Netherlands. All general practitioners and schooldoctors in this region were infomed of our study. The majority of patients were referred to our outpatient clinics by their general practitioner or schooldoctor. In some cases the children were seen at the pediatric wand, mostly on request of a surgeon. The Academic Hospital is the only hospital in town, therefore it is the major refertal site for local family doctors.

Patients were considered to suffer from RAP when they met the following criteria:

1). age range: 5.5 to 12 years,

2). a minimum of six months of recurrent abdominal pain of unknown origin,

3). attacks of pain varying in severity duration and frequency,

4). sometimes accompanied by vegetative symptoms as paleness, nausea and vomiting. The protocol consisted of two main parts. The "somatic" part has been reported previously (12), and consisted in short of the following elements: routine laboratory investigations of blood, urine and stools; a lactose breath hydrogen test; an uitrasound examination of the abdomen; a small bowel permeability test with "Cr labelled ethylenediaminetetraacetate ("Cr-EDTA) as a marker. Some of the patients also underwent a gastroduodenoscopy and a duodenal biopsy was taken. Results of these investigations have been published separately (chapter 3,4 and 7) $(6,12,13)$. All parents gave informed consent on their first visit to the outpatient clinics.

The "psychological" part of the protocol consisted of the following psychological tests carried out on the department of medical psychology:

1). The Dutch version of the Family Relation Test (FRT)(14) contains 86 questions, that refer to to 13 different topics concerning positive and negative feelings to and from the other nembers in the lamily, as seen by the child. In the test, people not belonging to the family are referred to as "nobody" and wher adressing positve or negative feelings can be used as an escape from not having to answer.

2). The Dutch Personality Questionnaire for Children (NPV-J)(15) consisting of five subscales: inadequacy (high sconers describe themselves as tense, anxious and feeling undervalued), persistence (high scores relate to characteristics like tranquility, conscientious with a positive attitude towards tasks and endurance), social inadeguacy (high scorers are less able to maintain social contacts), recalcitrance (high scorers are characterized by a suspicious and negative attitude) and dominance (high scores relate to characteristics like selfassured and not easy to influence).

3). The Amsterdam Biographic Questionnaire for Children $(A B V-K)(16)$ testing aspects of neurotic labulity, neurosomatic complaints, social extraversion and the attitude towards the test (sell-defensiveness).

4). The Achievement Motivation Test for Children (PMT-K)(17) particularly scoring the presence of positive and/or negative failure anxiety, achievement motivation and aspects of social adequacy. 
5). The Prognessiwe Matrices of Raven for a quick screening of intelligence, in order to have some control on the comprehension of the questionnaires.

A few days or weeks after the testing all children and their parents, preferably both parents, were seen by the child psychologist (AG). In a 90 minutes semi-structured interview the parents were asked about the presence of pain complaunts and suffering in other members of the family, about stressfactors such as learning problems, moving, confrontation with death or illness, family conflicts, problems in the upbringing with siblings and about signs of emotional distress such as fears, enuresis, encopresis, sleeping- or eating problems, difficult behavior at home and problems in peer interaction. The appointment with the psychologist was made during the first visit to the outpatient clinics. As a consequence, in those children where a somatic cause for the complaints was later found, the psychological tests had already taken place before the patient and parents were aware of the diagnosis.

The control group was integrated by children of 6 different primary schools on a voluntary basis and consisted of 86 children. The schools were chosen from the city of Maastricht, as well as from villages nearby. In collaboration with the schooldoctors, the heads of schools were asked to hand out an information leaflet, where parents were asked to allow their children to collaborate in the study. The control children were all tested at school or at the Department of Child Health, by the same assistant-psychologist. They were submitted to the same tests as the RAP patients. A fiew days to weeks later the interview with the psychologist $(\mathrm{AG})$ took place. For the present study onlly data conceming 9 to 12 year old children (patients and controls) were taken into account, because the tests chosen required a sufficient reading ability that made them suitable only for this age group.

The study group consisted of 51 children with RAP, who completed the psychological tests and underwent the interview. Of these 51 children, 30 had no definite diagnosis (functional group), and 21 had a possible somatic etiology (somatic group), such as lactose intolerance (12 cases), ulcerative colitis (1 case), gastroesophageal reflux (6 cases), food allergy ( 3 cases) and abdominal adhesions following appendectomy (1 case). Two children had both lactose intolerance and gastroesophageal reflux as well. The study and control group were matched for age, sex, intelligence according to the Progressive Matrices of Raven, family size, marial status, social class, parents' age and also for the presence of other diseases. Only results concerning the psychological texts are reported in the present paper and will be presented in a structured way, in which each variable will be compared in four different ways:

Comparison 1: Sudy Group $(n=51)$ ws Contol Group $(n=86)$

Comparison 2: Functional Group $(n=30)$ us Control Group $(n=86)$

Comparison 3: Somatic Group $(n=21)$ wi Control Group $(n=86)$

Comparison 4: Functional Group $(n=30)$ ws Somatic Group $(n=21)$

\section{Statistical Analysis}

Stanisticat analysis of the FRT results and personality questionnaires (NPV-J, ABV-K and PMT-K) was perfomed by the Wilcoxon two sample test for nomal approximation with a preestablished significance level of 0.01 . The interview data were analyzed with the Fisher's exact probability test (single -tailed) with the same level of significance. 


\subsection{Results}

\section{Study Group vs Control Group}

Table I shows our results from the FRT. In the study group we found significantly less ofter the use of "nobody" (the non-existing, outside member of the family), when adressing positive feelings; more positive foelings towards the mother; more overprotection by the mother and more spoiling by both mother and father $(\mathrm{p}=0.001)$. In tables 2 , 3 and 4 the results from the personality tests (NPV $-\mathrm{J}, A B V-K$ and $P M T-K)$ are given. The $A B Y-K$ only showed significantly more neurosomatic complaints in the study group $(p$ $=0.001)$. The NPV-J and the PMT-K showed no significant difference. The intervew showed significantly more pain complaints and suffering from disease in the patients" fathers $(34 \%$ ws controls: $16.4 \%)(\mathrm{p}=0.01)$. This was not the case in the childrens'

$\begin{array}{ll}\text { Study Group } & \text { Control Group } \\ (n=51) & (n=86)\end{array}$

$\begin{array}{lll}\text { Functional Somatic } & \text { Type of } \\ \begin{array}{ll}\text { Group } \\ (n=40)\end{array} & \text { Group } & \text { Comparison } \\ & (n=2 h) & \end{array}$

POSITIVE FEELINGS TOWARDS:

\begin{tabular}{lrrrrl}
\hline Nobody & 3.8 & 2.7 & 5.4 & 8.5 & $1 * 2 *$ and $4 * *$ \\
Mysell. & 1.2 & 1.1 & 1.4 & 1.7 & NS \\
Father & 9.5 & 10.3 & 8.5 & 8.4 & NS \\
Mother & 14.2 & 14.9 & 13.2 & 10.3 & $1^{*}$ and $2^{*}$ \\
SIBS & 7.6 & 7.9 & 7.2 & 5.8 & NS \\
\hline
\end{tabular}

NEGATIVE FEELINGS TOWARDS:

\begin{tabular}{lrrrrl}
\hline Nobody & 11.0 & 9.0 & 14.0 & 13.7 & $2^{*}$ \\
Myself & 2.2 & 2.7 & 1.5 & 2.0 & NS \\
Father & 6.2 & 6.8 & 5.5 & 4.3 & NS \\
Mother & 2.9 & 2.9 & 3.1 & 3.3 & NS \\
SIBS & 15.2 & 16.8 & 12.8 & 12.9 & NS \\
\hline Overprotection & 4.0 & 4.1 & 4.0 & 2.3 & $1^{*}, 2^{*}$ and $3^{*}$ \\
Spoiling Mother & 1.9 & 2.3 & 1.4 & 1.2 & $1^{*}$ and $2^{*}$ \\
Spoiling Father & 1.7 & 1.7 & 1.7 & 1.0 & $1^{*}$ and $2^{*}$ \\
\hline
\end{tabular}

"Comparison $I:$ study wis control group

comparison 3: somatic us control group comparison 2: functional ws control group comparison 4: funcrional ws somatic group

${ }_{\mathrm{p}} \mathrm{p}=0.001, * w_{\mathrm{p}}=0.004$ (Wilcoxon test). NS: not significant.

\section{Table 1:}

Mean raw scores of the Family Relation Test (FRT) 

Study Group
Cowhol Growp
$(n=51)$
$(n=86)$

$\begin{array}{ll}\text { Functional Somatic } & \text { Type of } \\ \text { Group Gromp } & \text { Companison }\end{array}$

$(n=30) \quad(n=2 n)$

\begin{tabular}{llllll}
\hline Inadequacy & 22.9 & 23.0 & 22.7 & 21.4 & NS \\
Persistence & 40.2 & 40.2 & 40.2 & 39.6 & NS \\
Social inadequacy & 13.4 & 14.8 & 11.4 & 12.9 & NS \\
Recalcitrance & 24.0 & 22.6 & 26.0 & 21.3 & NS \\
Dominance & 12.2 & 11.9 & 12.8 & 11.9 & NS
\end{tabular}

"comparison I: sudy us control group

comparison 3: somatic us control group comparison 2: functional ws control group comparison 4: functional ws somatic group

NS: not significant

\section{Table 2:}

Personality tests: mean raw scores of the Dutch Personality Questionnaire for Children (NPV-J)

$\begin{array}{ll}\text { Study Group } & \text { Control Group } \\ (n=51) & (n=86)\end{array}$

$\begin{array}{ll}\text { Functional Somatic } & \text { Type of } \\ \text { Gromp Group } & \text { Comparison } \\ (n=30) & \text { Git }\end{array}$

\begin{tabular}{|c|c|c|c|c|c|}
\hline Neurotic Lability & 15.6 & 16.2 & 14.7 & 14.6 & NS \\
\hline Neurosom. Complaints & 11.0 & 11.0 & 11.0 & 8.6 & $1^{*}, 2^{\text {sto }}$ and $3^{\text {* }}$ \\
\hline Social Extraversion & 22.5 & 22.2 & 22.8 & 23.2 & NS \\
\hline Testattitude & 9.1 & 9.2 & 9.1 & 9.2 & NS \\
\hline
\end{tabular}

comparison J: sndy ns comol group comparison 2 functional us control group comparison 3: somatian wowlot growp comparison 4: functional vo somatic group

${ }^{*} p=0.001$ (Wilcoxon test). NS: not significant

\section{Table 3:}

Personality tests: mean raw scores of the Amsterdam Biographic Questionnaire for Children $(A B V-K)$ 
$\begin{array}{ll}\text { Sindy Group } & \text { Control Gromp } \\ (n=51) & (n=86)\end{array}$

Functional Somatic Type of

Group Group Comparison

\begin{tabular}{lrrrrr}
\hline Prestation Motivation & 17.7 & 18.4 & 16.5 & 19.4 & NS \\
Neg. Failure Anxiety & 8.6 & 8.9 & 8.2 & 7.5 & NS \\
Pos. Failure Anxicty & 8.9 & 8.2 & 10.0 & 9.8 & NS \\
Social Desirability & 10.8 & 10.5 & 11.2 & 11.1 & NS
\end{tabular}

"cowparifon 1: study ws control group

NS: not significant

\section{Table 4:}

Personality tests: mean raw scores of the Achievement Motivation Test for Children (PMT-K)

\begin{tabular}{|c|c|c|c|c|c|}
\hline & \multicolumn{3}{|c|}{$\begin{array}{l}\text { Study Group } \\
(n=51)\end{array}$} & \multicolumn{2}{|c|}{$\begin{array}{l}\text { Control Group } \\
(n=86)\end{array}$} \\
\hline & & $\begin{array}{l}\text { Functio } \\
\text { Gromp } \\
\text { insonil }\end{array}$ & $\begin{array}{l}\text { Somañic } \\
\text { Group } \\
(n=2 n\end{array}$ & & $\begin{array}{l}\text { Type of } \\
\text { Comparison" }\end{array}$ \\
\hline Learning Problems & 27.4 & 30.0 & 23.8 & 16.3 & NS \\
\hline $\begin{array}{l}\text { Moving } \\
\text { Confrontation with }\end{array}$ & 15.7 & 10.0 & 23.8 & 7.0 & NS \\
\hline Death or illness & 29.4 & 36.7 & 19.0 & 24.4 & NS \\
\hline $\begin{array}{l}\text { Family Conflicts } \\
\text { Upbringing Problems }\end{array}$ & 33.3 & 36.7 & 28.6 & 15.1 & $1 *$ and $2 *$ \\
\hline with SIBS & 39.2 & 53.3 & 19.0 & 11.6 & $1 *, 2 *$ and $4 *$ \\
\hline
\end{tabular}

${ }^{*} p=0.01$ (Fisher's test). NS: not significant

\section{Table 5:}

Results from the interview: Stressfactors (\% present) 
Srudy Group

$(n=51)$
Connol Gromp

$(n=86)$

$\begin{array}{lll}\text { Functional } & \text { Somatic } & \text { Type of } \\ \text { Gromp } & \text { Group } & \text { Comparison } \\ (m=30) & (n=2 n) & \end{array}$

\begin{tabular}{lrrrrl}
\hline Fear & 27.5 & 30.0 & 23.8 & 17.4 & NS \\
Enuresis & 6.0 & 6.7 & 5.0 & 4.7 & $\mathrm{NS}$ \\
Sleeping Problems & 17.7 & 20.0 & 14.3 & 8.1 & $\mathrm{NS}$ \\
Eating Problems & 29.4 & 30.0 & 28.6 & 7.0 & $1^{*}, 2^{\text {* }}$ and $3^{*}$ \\
Difficult Behavior & 29.4 & 33.3 & 23.8 & 8.1 & $1^{*}$ and $2^{*}$ \\
$\begin{array}{l}\text { Difficulties in } \\
\text { Peer Interaction }\end{array}$ & 41.2 & 50.0 & 28.6 & 5.8 & $1^{\text {** }}, 2^{*}$ and $3^{*}$
\end{tabular}

"comparison 1: study ws control group

comparison 3: somatic ws control group

comparisan 2: functional is control group

comparison 4: functional us somatic group

$* p=0.001$ (Fisher's test). NS: not significant

\section{Table 6:}

Results from the Interview: Signs of Emotional distress (\% present)

mothers and siblings. Table 5 shows the presence of stress factors. In the study group significantly more family conflicts and problems in the upbringing of siblings were noticed $(p=0.01)$. All other stress factors did not display a significant difference. Table 6 illustrates the presence of emotional distress. We found more eating problems, more difficult behavior and difficulties in peer interaction in the study group $(p=0.001)$ (table 6).

\section{Functional Group vs Control Group}

In the comparison of these groups the same differences as described above were seen, with exception of the FRT, in which the functional group presented significantly less negative feelings towards "nobody" ( $p=0.004)$ (able 1).

\section{Somatic Group vs Control Group}

In the FRT, as shown in table 1, the somatic group only showed more signs of overprotection $(\mathrm{p}=0.001)$. In the personality tests the same results as mentioned in comparison 1 and 2 were observed (table 2,3 and 4). Results from the interview dicl not demonstrate the presence of stressfactors (table 5), nor the presence of difficult behavior as a sign of emotional distress (table 6).

\section{Functional Group vs Somatic Group}

In the FRT the functional group used "nobody" significantly less in adressing positive feelings $(p=0.004)$ (table 1). No differences were found in the personality tests (table 2, 3 and 4). From the interview the somatic group demonstrated significantly less problems in the upbringing with siblings $(\mathrm{p}=0.01$ ) (table 5 ). No differences were observed regarding the presence of emotional distress (table 6). 


\subsection{Discussion}

Abdominal pain can be a symplom appearing in a number of psychopathological conditions such as schoolphobia, child abuse and somatisation disorders. Although convincing evidence is lacking the RAP syndrome generally seems to be accepted as a predominanily psychosomatic disorder. Factors like environmental stress, family distress or depression and personality traits are thought to play an important rolle in its etiology $(7,8)$. On the other hand, certain physical disorders, like lactose intolerance (4), abnormal gastroduodenal motility (5) or inflammatory bowel disease (6), are considered to be causes of the RAP syndrome. Hence, this dichotomic way of thinking in terms of physical or psychological etiologies, often leads to the use of "psychogenic" as a synonym for "unknown etiology". Apley stated that the etiological importance of psychological factors needs to be proven (3). In this context it would be conceivable that there are personality differences between children with RAP and pain-free children. However, our study shows that when comparing a matched control group to a large, carefully assembled group of children refened for RAP, the personality tests, from which the most informative results were to be expected, failed to show essential differences between RAP patients and our control group. In this context, it should be realized that the significant difference we found between the study and control group concerning neurosomatic complaints can be explained by the nature of the test items. About one third of the questions on this subscale referred to feeling healthy or to having complaints such as abdominal pain or other symptoms.

Most psychological disturbances observed are equally present in both groups. The psychological factors differing significantly between the groups, appeared to be predominantly environmental ones, such as family conflicts and problems in the upbringing. The presence of such factors might be the consequence of the disease itself, being used as a way to profit from the complaints, rather than of causative origin. Several studies have investigated the role of stress factors in children with RAP. In their study, McGrath et al (10) observed no difference in the amount of life change experienced by children with RAP and pain-free controls. Similarly, Raymer et al (11) found that children with RAP were under the same amount of stress as pain-fiee controls.

Compared 10 our control group both the somatic and functional group of patients showed the presence of frequent pain complaints and suffering from disease in their parents and siblings. A significant difference was, however, found in the patient's fathers only. These findings confirm the existence of "painful families" in patients with clronic pain, as was previously reported by other authors $(2,18,19)$. These pain complaints might work as a modelling factor in the patients' abdominal complaints.

Artother important finding in our study is the fact that there are no essential differences on psychological grounds between the functional and somatic group. This again, does not support the assumption that psychological factors play an important role in the pathogenesis of the RAP syndrome in children.

From the observations of our study, we conclude that there appeared to be no differences in personality traits between children with RAP and control children. The psychological status of the average RAP child should, therefore, be considered as nomal. Our findings futher show that some stress factors and some signs of emotional distress are slightly more frequent in RAP children, but statistically significant. Although stress factors could be responsible for RAP in our patients, the fact that they were only found in the minority of our study group, suggest that they are only rarely implicated in the RAP syndrome. 
As to the presence of signs of emotional distress, they are in our opinion not sufficient to explain the origin of RAP in children, and they more likely represent factors involved in coping with the pain (20). It is our contention that psychological factors are only rarely involved in the pathogenesis of $\mathbb{R A P}$ in children. 


\subsection{References}

(1): Apley J and Naish N. Recurrent Abdominal Pains: a field survey of 1000 school chilklren. Arch Dis Child 1958; 33: 165-70

(2): Kellmer Pringle ML, Buller NR and Dave R. National Child Development Study (1958 cohort), p 184. London, Humanities Press, 1966.

(3): Apley J: The child with abdominal pains, 2nd edition, Oxford, Blackwell Scientific Publications, 1975.

(4): Barr $\mathrm{G}$, Levine DL and Watkins JB. Recurrent Abdominal Pain of Childhood due to lactose intolerance. New Engl J Med 1979; 26: 1449-1452

(5): Pineiro-Carrero WM, Andres JM, Davis RH and Mathias JR. Abnormall gastroduodenal motility in children and adolescents with recurrent functional abdominal pain. I Pediatr 1988; 5: 820- 5

(6): van der Mer SB, Forget PP and Arends JW. Abnormal small bowel permeability and duodenilis in recurrent abdominal pain. Arch Dis Child 1990; 65: $1311-1314$.

(7): Crossley RB. Hospital admissions for abdominal pain in childhood. I Roy Soc Med 1982; $75: 772-776$

(8): Faull $C$ and Nicol AR. Abdominal pain in six-year oids: An epidemiological study in a new town. J Chilld Psychol Psychiatr 1986; 27: 251-260

(9): Apley J, Hale B. Children with Recument Abdominal Pain: How do they grow up ? Br Med J 1973; 3: 7-9.

(10): MoGrath PJ, Goodman JT, Firestone P, Shipman R and Peters S. Recurrent Abdominal Pain: a psychogenic disorder ? Arch Dis Child 1983; 58: 888 - 890

(11): Raymer D, Weininger $O$ and Hamilton JR. Psychological problems in children with abdominal pain. Lancet 1984; i: 439 - 440

(12): wan der Meer SB, Forget PP and Heidendal GAK. Small bowel permeability to $\mathrm{Cr}$ EDTA in chilldren with recurrent abdominal pain. Acts Paed Scand 1990; 79: 422-426.

(13): van der Meer SB, Forget PP, Kuijten RH, Arends JW and van Engelshoven JMA. Diagnostic value of ultrasound in recurrent abdominal pain in children. Ped Radiol 1990; 20: $501-503$

(14): Baarda DB, van London A en van London-Barentsen WM. Familie Relatie Test, experimentele uitgave. Lisse, Swets and Zeitlinger. 1983.

(1.5): Luteijn Fo, van Dijk H en var der Ploeg FAE. Junior Nederlandse Persoonlijkheids Vragenlijst, NPV-J. Lisse, Swets en Zeitlinger, 1981.

(16): Van Dijl Hen Wilde GJS. Handleiding bij de Amsterdamse Biografische Vragenlijst voor Kinderen, $\mathrm{ABV}-\mathrm{K}$, en de Korte Amsterdamse Biografische Vragenlijst voor Kinderen, KABV-K. Second edition, Amsterdam, F. van Rossen, 1982.

(17): Hemans HJM. Prestatiemotivatie en faalangst in gezin en onderwijs. Lisse, Swets en Zeitlinger, $197 \|$.

(18): Stone RT and Barbero G.. Recurrent abdominal pain in childhood. Pediairics 1970; 45: 732-738.

(19): Christensen MF and Mortensen O. Longterm prognosis in children with recurrent abdominal pain. Arch Dis Child 1975; 50: 110-114.

(20): McGrath PJ and Feldman W. Clinical approach to recurrent abdominal pain in children. Dev Behav Pediatr 1986; 7: 56-61. 


\section{Small Bowel Permeability to ${ }^{51} \mathrm{Cr}$-EDTA in Recurrent Abdominal Pain}

S.B. van der Meer, P.P. Forget, G.A.K. Heidendal

\section{Summary}

Small bowel permeability was investigated in 87 children with recurrent abdominal pain by measuring the 24-h urinary excretion of orally administered "Cr-EDTA. The mean excretion was $3.64 \% \pm 1.49 \% / 24$ hrs. The difference between the mean urinary excretion in children with recurrent abdominal pain and control children $(2.51 \% \pm 0.70 \%)$, was significant $(\mathrm{p}<0.01$, two sample t-test). The increased small bowel permeability in children with recurrent abdominal pain might indicate an intestinal etiology for the patients' complaints.

(Acta Paediatrica Scandinavica 1990; 79: 422 - 426) 


\subsection{Introduction}

Recurrent abdominal pain (RAP) is a frequently encountered complaint in childhood. Large series in different studies have shown that $10 \%$ of schoolchildren regularly complain of abdominal pain. In only 5-10\% of these children a somatic explanation could be found, whereas in the other patients a psychosocial condition was thought to be the main reason for the complaints (1). However, McGrath et al (2) could not show a relationship between RAP and psychosocial conditions. Recently small bowel permeability tests have been developed to detect small bowel lesions $(3,4)$. Small bowel permeability is evaluated by measuring urinary excretion of "chromium labelled ethylenediaminetetraacetate ("Cr-EDTA) after oral intake. Urinary excretion of "Cr-EDTA has been reported to be raised in several diseases associated with mucosal inflammation and/or atrophy (Crohn's disease, gastroenteritis, celiac disease) $(5,6)$. This increased small bowel permeability reverts to normal after healing of the lesions (6). The simplicity and sensitivity of the test is an important advantage, especially in pediatric patients. The aim of the present study, was to evaluate small bowel permeability in children with RAP as a possible indicator for the presence of small bowel lesions.

\subsection{Patients and Methods}

Patients were considered to suffer from RAP when the following criteria were met: 1). age range 5.5 to 12 years,

2). a minimum of six months of recurrent abdominal pain of unknown origin,

3). attacks of pain varying in severity, duration and frequency,

4). sometimes accompanied by vegetative symptoms such as paleness and nausea.

These criteria are slightly different from those in the literature, where a three months period is often considered sufficient $(1,3)$. Patients were referred to our out-patient clinics by their general practitioners or by school doctors. Both groups of colleagues were informed about the study. All parents gave informed consent. The protocol consisted of a thorough physical examination and routine laboratory investigations of blood, faleces and urine. An ultrasound examination of the abdomen was performed by a standard procedure. Laclose tolerance was tested with an orall lactose load of $2 \mathrm{gr} / \mathrm{kg}$, with a maximum of $50 \mathrm{gr}$. Breath samples were analyzed using a Lactoscreen $(\mathrm{B}$ (HockLoos). Values were considered abnomal when exceeding $20 \mathrm{ppm}$. A few days later a "Cr-EDTA permeability test was performed as follows: After an overnight fast, $100 \mu \mathrm{Cu}$ "Cr-EDTA were given orally in $10 \mathrm{ml}$ dilution of $5 \%$ glucose. The cup was rinced with water. Free food and drinks were allowed 2 hours later. Urine was collected for 24 hours. Urine volumes were measured and two samples of $5 \mathrm{ml}$ each were counted in a well-counter. A standard 1:100 dilution of $5 \mathrm{ml}$ was similarly counted. Radioactivity excreted in the urine over a period of 24 hours was expressed as a percentage of the oral dose. The estimated absorbed dose was $<5$ mrad to total body, $<10$ mrad to stomach or small bowel, $<150$ mrad to large bowel and $<20 \mathrm{mrad}$ to gonads (7). Normal values for children and adults have been previously published and are shown in figure 1 (7). These values were detived from children (ages ranged from 0.8 to 12 years) which presented with poor growth. After extensive investigation this could only be ascribed to environmental factors (social deprivation). None showed any gastrointestinal symptoms. These values correspond fairly with data published by other authors $(5,6)$. 


\subsection{Results}

Ninety-four patients entered the study. In 87 cases a ar-EDTA-test was performed. In. 7 cases either the parents refused the test, or urine sampling failed. The results are shown. in figure 1.

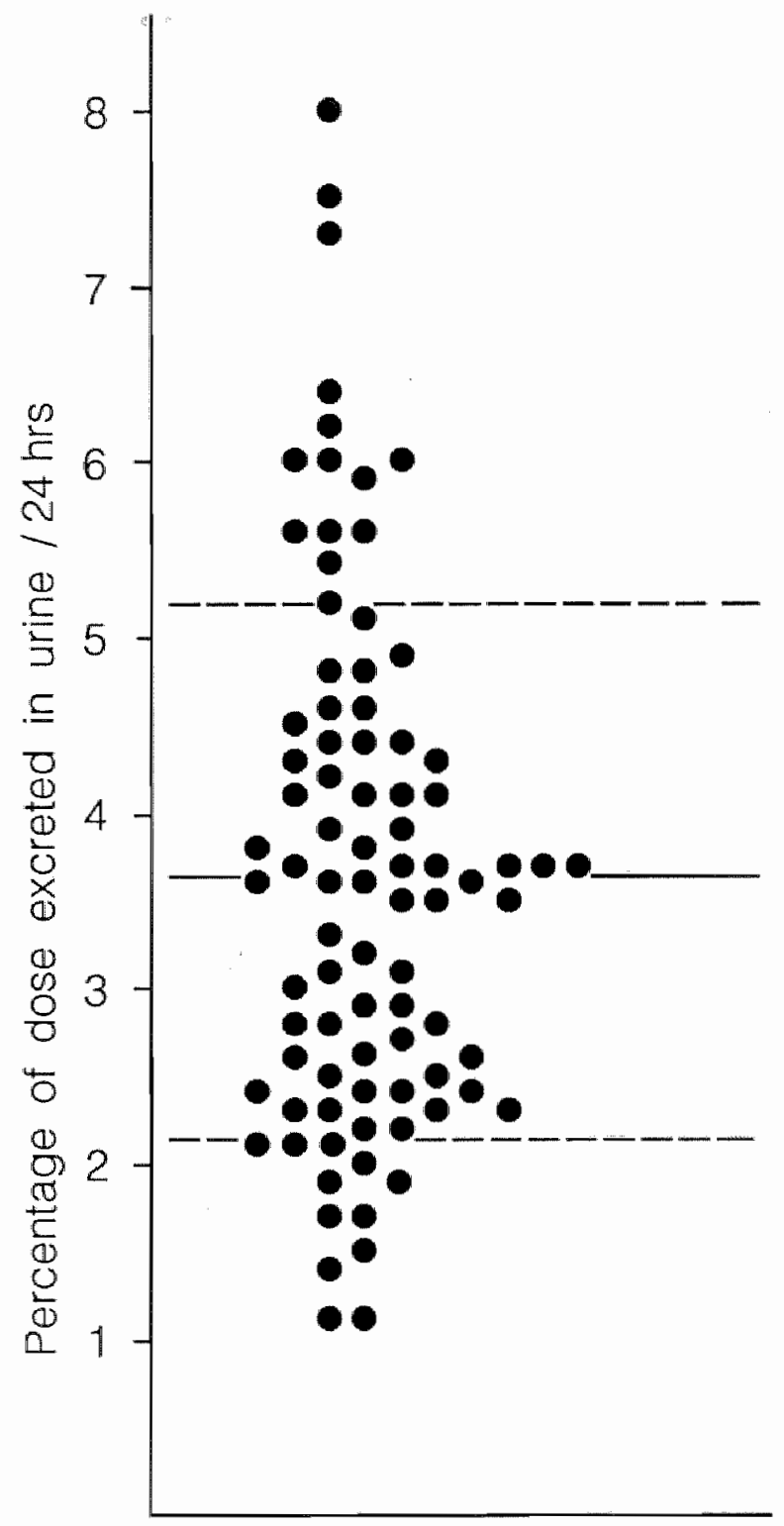

Children with RAP

\section{Figure 1:}

The 24-h urinary excretion of "Cr-EDTA in children with recurrent abdominal pain (individual values, mean and standard deviation). 


\subsection{Introduction}

Recutrent abdominal pain (RAP) is a frequently encountered complaint in childhood. Large series in different studies have shown that $10 \%$ of schoolchildren regularly complain of abdominal pain. In only 5-10\% of these children a somatic explanation could be found, whereas in the other patients a psychosocial condition was thought to be the main reason for the complaints (1). However, McGrath et al (2) could not show a relationship between RAP and psychosocial conditions. Recently small bowel permeability tests have been developed to detect small bowel lesions $(3,4)$. Small bowel permeability is evaluated by measuring urinary excretion of "chromium labelled ethylenediaminetetaacetate ("Cr-EDTA) after oral intake. Urinary excretion of "Cr-EDTA has been reported to be raised in several diseases associated with mucosal inflammation and/or atrophy (Crohn's disease, gastroenteritis, celiac disease) $(5,6)$. This increased small bowel permeability reverts to normal after healing of the lesions (6). The simpliciry and sensitivity of the test is an important advantage, especially in pediatric patients. The aim of the present study, was to evaluate small bowel permeability in children with RAP as a possible indicator for the presence of small bowel lesions.

\subsection{Patients and Methods}

Patients were considered to suffer from RAP when the following criteria were met: 1). age range 5.5 to 12 years,

2). a minimum of six months of recurrent abdominal pain of unknown origin,

3). atlacks of pain varying in severity, duration and frequency,

4). sometimes accompanied by vegetative symptoms such as paleness and nausea.

These criteria are slightly different from those in the literature, where a three months period is often considered sufficient $(1,3)$. Patients were referred to our out-patient clinics by their general practitioners or by school doctors. Both groups of colleagues were informed about the study. All parents gave informed consent. The protocol consisted of a thorough physical examination and routine laboratory investigations of blood, lacees and urine. An ultrasound examination of the abdomen was performed by a standard procedure. Lactose tolerance was tested with an oral lactose load of $2 \mathrm{gr} / \mathrm{kg}$, with a maximum of $50 \mathrm{gr}$. Breath samples were analyzed using a Lactoscreen $\mathbb{B}$ (HockLoos). Values were considered abnormal when exceeding $20 \mathrm{ppm}$. A few days later a "Cr-EDTA permeability test was performed as follows: After an overnight fast, $100 \mu \mathrm{Cu}$ "Cr-EDTA were given orally in $10 \mathrm{ml}$ dillution of $5 \%$ glucose. The cup was rinced with water. Free food and drinks were allowed 2 hours later. Urine was collected for 24 hours. Urine volumes were measured and two samples of $5 \mathrm{ml}$ each were counted in a well-counter. A standard 1:100 dilution of $5 \mathrm{ml}$ was similarly counted. Radioactivity excreted in the urine over a period of 24 hours was expressed as a percentage of the oral dose. The estimated absorbed dose was $<5$ mrad to total body, $<10$ mrad to stomach or small bowel, $<150 \mathrm{mrad}$ to large bowel and $<20$ mad to gonads (7). Normal values for children and adults have been previously published and are shown in figure 1 (7). These values were derived from children (ages ranged from 0.8 to 12 years) which presented with poor growth. After extensive investigation this could only be ascribed to environmental factors (social deprivation). None showed any gastrointestinal symptoms. These values comespond lainly with data published by other authors $(5,6)$. 


\subsection{Results}

Ninety-four patients entered the study. In 87 cases a CI-EDTA-test was perfomad. In 7 cases either the parents refused the test, or urine sampling falled. The results are shown in figune 1 .

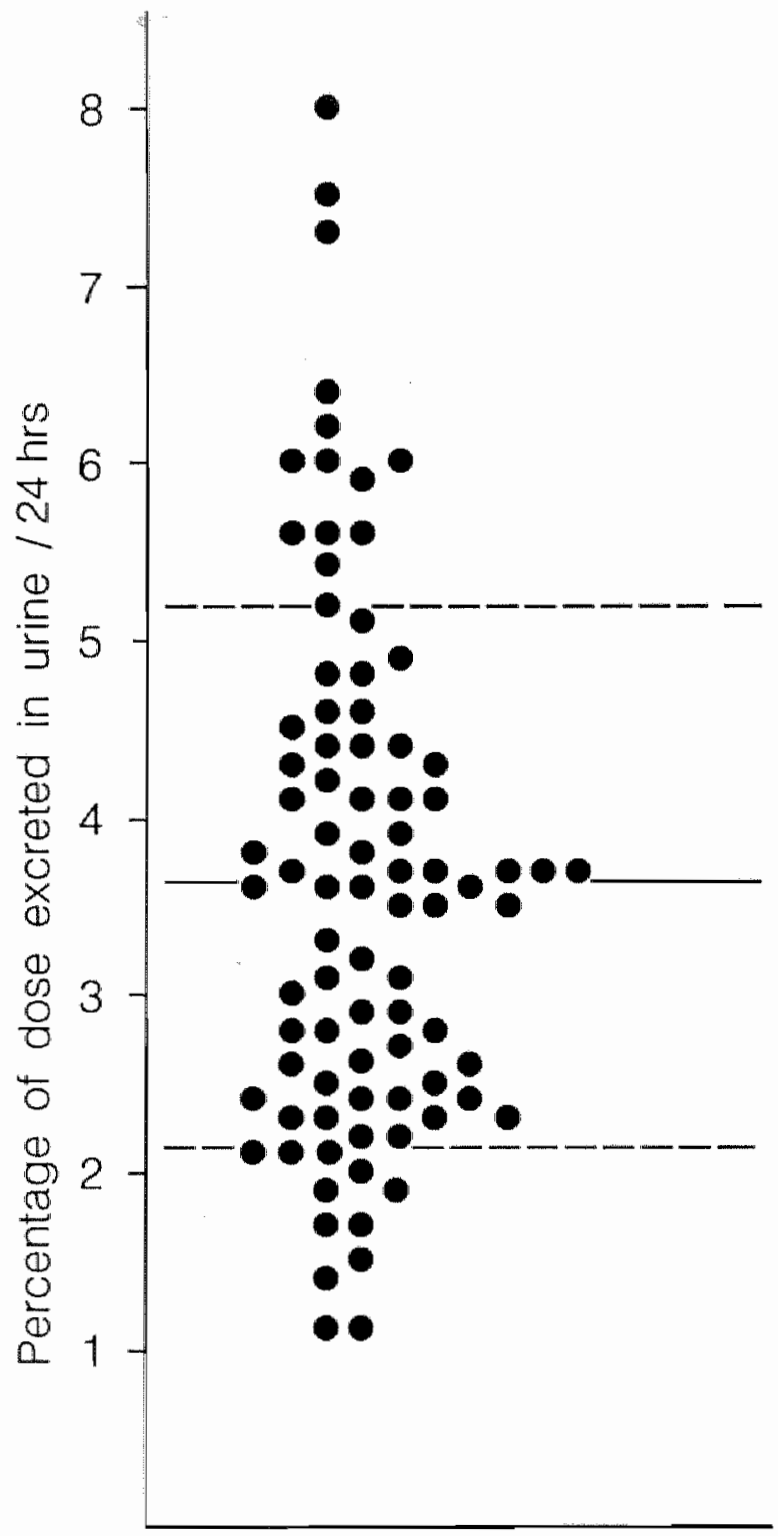

\section{Children with RAP}

Figure 1:

The 24-h urinary excretion of ${ }^{51} \mathrm{Cr}$-EDTA in children with recurrent abdominal pain (individual values, mean and standard deviation). 
The mesn urinary excretion of "Cr-EDT A in all patients was $3.64 \%$ (standard deviation $1.49 \%$, range $1.1-8 \%$ ). In 47 cases $(54 \%)$ we found values higher than $3.5 \%$, considered lo be the upper linit for nomal in children (8). The differences between the mean uninary excrelion in children with RAP and values of children $(2.51 \% \pm 0.70 \%)$ and adults $(235$ $\pm 0.77 \%$ ) reported by Forget et al $(7)$, were significant $(\mathrm{p}<0.01$; t-tesi) (figure 2 ).

Periumbilical pain was reported in $42 \%$ of the patients. Associated symptoms and signs were: nausea (39\%), vomiting (31\%), anorexia $(35 \%)$, paleness $(32 \%)$ and headache (18\%). Physical examination did not reveal any abnomalities. We found no abnormalities in the routine laboratory inwestigations of blood, faeces and urine. The ultrasound examination of the abdomen was nomal in all patients. In 73 out of 94 patients a lactose breath hydrogen test was performed. In 11 out of 73 patients (15\%) the breath hydrogen excretion wats elevated (>20 ppm). These 11 children had a mean urinary "Cr-EDTA excretion of $3.36 \% \pm 1.63 \%$. The differences between the mean urimary excretion in children with lactose intolerance and values of children $(2.51 \% \pm 0.70 \%)$ or adults $(2.35 \% \pm 0.77 \%)(7)$, were signilicant $(\mathrm{p}<0.01$; t-test).

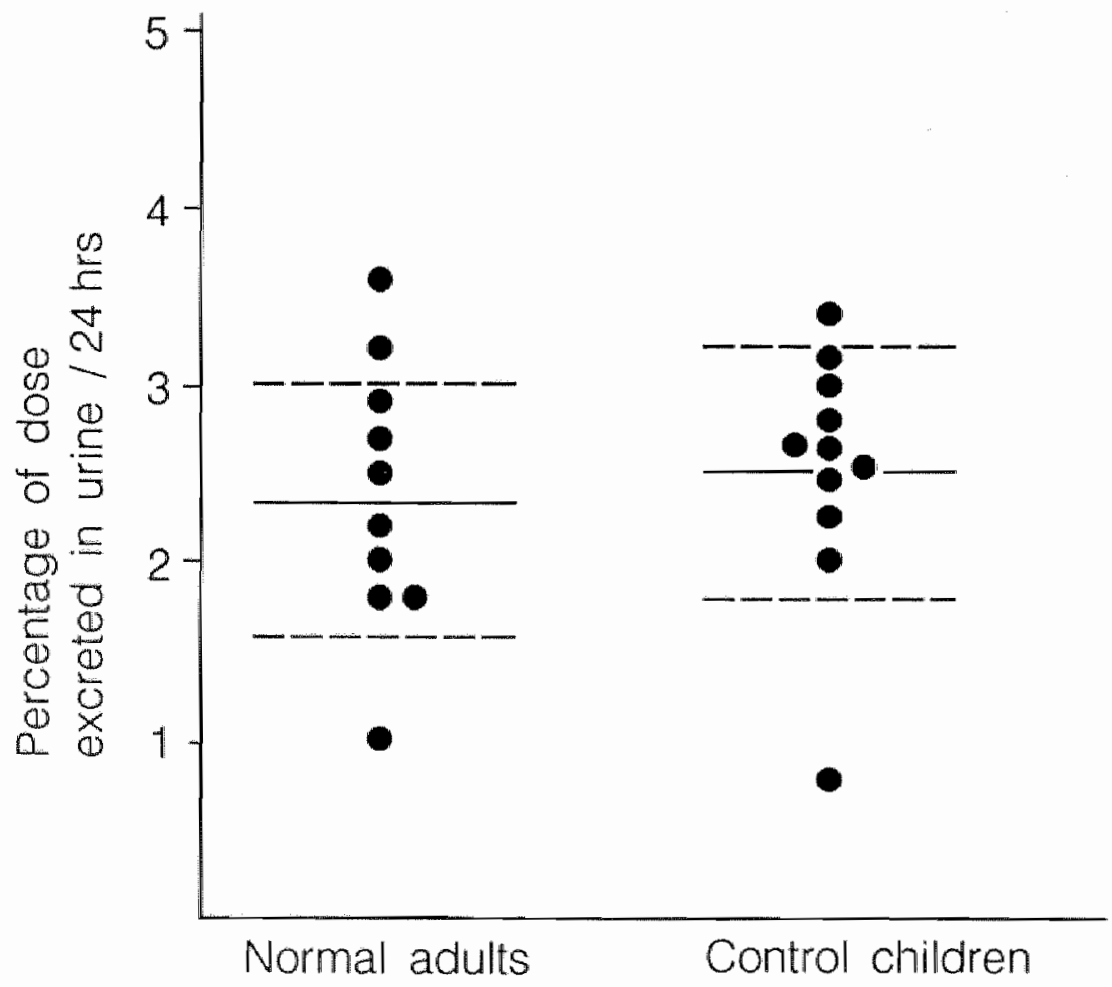

Figure 2:

The 24-h wrinary excretion of "Cr-EDTA in normal adults and control children (individual values, mean and standard deviation). 


\subsection{Discussion}

Most children with RAP present periumbilical pain. The periumbilical region is known to be the referral site for pain originating in the small bowel. This was pointed out by Apley years ago, but because of lack of evidence for small bowel disease he thouglat that psychogenic factors were a more likely cause for this puzzling syndrome (1).

However, a recent study comparing 30 children with RAP and 30 pain free children failed to show a significant difference by applying a variety of psychosocial tests (2). Attention was drawn to other somatic explanations as lactose intolerance (8). There is some dispute over the meaning of lactose intolerance as a cause of recurrent abdominal pain in childhood (9). In our patients the lactose breath-hydrogen test was elevated in 11 cascs (>20 ppm), in 9 of these children the abdominal pain disappeared on a lactose-poor diet and reappeared when lactose was reintroduced. This might suggest a possible associaiion. We do not know whether the increased "Cr-EDTA excretion in our laciosemalabsorption patients is either a chance finding or whether there is a causal relationship between lactose-malabsorption and small bowel permeability.

"Cr-EDTA is thought to cross the small intestinal wall through the tight junctions between the enterocytes. The exact mechanism however is at present unknown $(10)$. Several studies have reported values of 3 to $3.5 \%(5,7,11)$ as the upper limit for normal "Cr-EDTA excretion. About half of our patients with RAP showed an increased "ClEDTA excretion (54\%).

Since the absorption of "Cr-EDTA predominantly takes place in the small bowel (4), the increased excretion found in our patients, may suggest small bowel abnormalities. Urinary excretions of :Cr-EDTA after oral administration has been reported to be abnomal in several conditions, known to be associated with mucosal inflammation such as in celiac disease (5), and in Crohn's disease when the small bowel is affected (4). The increased bowel permeability reverts to normal with treatment (6).

Children with infantile gastroenteritis and/or eczema, both known to be associated with mucosal inflammation, have also an increased intestinal permeability for "Cr-EDTA (11).

Similarly an increased permeability to lactulose is present in children with acute gastroenteritis and chronic cliarrhea (12). In the latter sludy abnormal small bowel morphology was strongly associated with increased permeability (12). Consequently. we speculate that many children with RAP have a chronic inflammatory enteropally. Due to its high sensitivity, the "Cr-EDTA permeability test might have revealed a so far" undetected small bowel defect, probably reflecting a local inflammatory state.

Several studies have pointed out the presence of duodenitis in many children with chronic abdominal pain $(13,14,15)$. Although the degree of duodenitis, was not severe in most of these children, some authors consider these changes to be the precursor of fullblown duodenitis (14). The relationship between these inflammatory changes on the one hand, and abdominal pain on the other remains, however, uncertain (13). Intestinal inflammation results in changes in bowel function, which includes the loss of its ability to act as an effective barrier to antigenic macromolecules (16). The permeability defect could therefore result in a hypersensitivity reaction leading to damage and disease. Furthermote, the hypersensitivity reaction itself might result in progressive inflammation. Although we do not know the cause of the increased intestinal permeability present in our patients, we think either infectious agents or food antigens to be the likely causative factors. 
Infectious agerts are known to casse mucosal damage leading to increased "Cr-EDTA permeability (16). The changes in the epithelium seem to be caused by an immunologic reaction wather than to the infective agent itself. An immunologic reaction caused by hypersensitivity to food-antigens is an atractive explanation as a cause for the increased pemeability to $\mathrm{Cr}$-EDTA found in our patients. Further studies are in progress in order to characterize the nature of intestinal mucosal abnormalities in patients with RAP and the mechanisms involved. 


\subsection{References}

(1): Apley J: The child with abdominal pains. Ed. 2, Oxford, Blackwell Scientific Publications, 1975.

(2): McGrath PJ, Goodman JT, Firestone P, Shipman R and Peters S: Recurrent abdominal pain: a psychogenic disonder? Arch Dis Child, 1983; 58: 888.9

(3): Barr RG: Recurrent Abdominal Pain. How appropriate are our basic climical assumptions? In: Pediatric and adolescent behavioral medicine: issues in treatment. New York: Springer 1983.

(4): Bjamasson I, O'Morian C, Levi AJ and Peters TJ: Absorption of schromium labelled EDTA in inflammatory bowel disease. Gastroenterology $1983 ; 85: 318-322$.

(5): Bjamasson I, Peters TJ and Veal N: A persistent defect in intestinal pemeability in

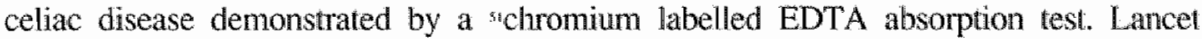
1983; 1 : $323-325$.

(6): Jenkins RT, Jones DB, Goodacre RL, Collins SM, Coates G, Hunt RH and Bienenstock J: Reversibility of increased intestinal permeability to :Cr-EDTA in patients with gastrointestinal infllammatory diseases. Am J Gastroenterol 1987; 82: 1159. 1164.

(7): Leclercq-Foucart J, Forget PP and Zappitelli A: Intestinal permeability to "CT-EDTA in children with Cystic tibrosis. I Paediatr Gastr Nutr 1986; 5: 384-387.

(8): Barr RG, Levine MD and Watkins JB: Recurrent abdominal pain of childhood due to lactose intolerance, a prospective study. N Engl J Med 1979; 300: 1449-52.

(9): Lebenthal E, Rossi TM, Nord KS and Branski D: Recurrent abdominal pain and lactose malabsorption in children. Pediatrics 1981; 67: 828-32.

(10): Tagesson C, Andersson PA, Andersson T and Bolin T: Passage of molecules through the wall of the gastrointestinal tract. Scand J Gastroenterol 1983: 18: 481-486. (11): Forget PP, Sodoyez-Goffaux F and Zappitelli A: Permeability of the small bowel intestine to "Cr-EDTA in children with acute gastroenteritis or eczema. J Pediatr Gastroenterol Nutr 1985; 4: 393-396.

(12): Ford RPK, Menzies IS, Phillips AD, Walker-Smith JA and Tumer WA: Intestinal Sugar Permeability: relationship to diarrheall disease and small bowel morphology. J Pediatri Gastroenterol Nutr 1985; 4: 568-574.

(13): Ament ME and Christie DL_: Upper Gastrointestinal Fiberoptic Endoscopy in Paediatric Patients. Gastroenterology 1977; 72:1244-8.

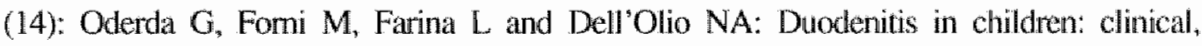
endoscopic and pathological aspects. Gastrintest Endosc 1987; 5: 366-9.

(15): Black DD, Haggitt RC and Whitington PF. Gastroduodenal endoscopic-histologic correlation in paediatric patients. J Paed Gastroenterol Nutr 1988; 7: 353-8.

(16): Ramage JK, Stanisz A, Scicchitano R, Hunt RH and Perdue H: Effect of Immunologic Reactions on $\mathbb{R}$ at Intestinal Epithelium. Gastroenterology 1988; 94: 136875 . 


\section{Abnormal Small Bowel Permeability and Duodenitis in Recurrent Abdominal Pain}

S.B. van der Meer, P.P. Forget, J.W. Arends

\section{Summary}

Thirty nine children with recurrent abdominal pain aged between 5.5 and 12 years, underwent endoscopic duodenal biopsy to find out if there were any duodenal inflammatory changes, and if there was a relationship between duodenal inflammation and intestinal permeability to "Cr-EDTA. Duodenal inflammation was graded by the duodenitis scale of Whitehead et al (grade $0,1,2$ and 3 ). In 13 out of 39 patients ( $33 \%$ ) definite signs of inflammation were found (grade 2 and 3 ). Intestinal permeability to "Cr-EDTA in patients with duodenitis (grade 1, 2 and 3 ) was significantly higher $(4.42 \pm 1.73 \%$ ) than in patients with normal (grade 0) duodenal biopsy appearances $(3.3 \pm 0.9 \%)$. A significant association was found between duodenal inflammation and abnormal intestinal permeability. Our results give further evidence that there is an intestinal origin of these patients' complaints.

(Archives of Disease in Childhood 1990, 65: 1311 - 1314) 


\subsection{Introduction}

About $10-15 \%$ of school-aged children regularily complain of abdominal pain $(1,2)$. In most cases no evident underlying cause can be found. In a large study done in 1958, Apley claimed to be able to find somatic causes, such as urinary ract infections and peptic ulcers, in only $10 \%$ of the patients (2). Since then various other possible causes have been suggested, including lactose intolerance (3), almomal gastroduodenal motility (4) and even 'appendiceal colic' (5). Much attention has been drawn by psychosocial conditions as a potential cause of the complaints $(6,7)$. Case controlled studies, however, did not establish a clear relationship between abdominal pain and psychosocial conditions $(8,9)$.

In a previous study we report abnomal intestinal permeability in children with recurrent abdominal pain (RAP), using orally administered "Chromium labelled ethylenediamine tetraacetave ("Cr-EDTA) as a marker (chapter 3) (10). In 54\% of our patients we found that the "Cr-EDTA excretion was more than $3.5 \%$, considered to be the upper limit of the reference range in children (11). As the urinary excretion of sCr-EDTA has been shown to be abnomal in several conditions known to be associated with mucosal inflammation such as coeliac disease (11), Crohn's disease (12) and gastroenteritis (13), we suggested that intestinal inflammation may be present in our patients with RAP. We had no histologic evidence to support this hypothesis, however. The purpose of the present study therefore was to find out the incidence of intestinal inflammation in our patients with RAP and to assess the value of "Cr-EDTA permeability tests in relation to intestinal inflammation. As the absorption of "Cr-EDTA takes place predominantly in the small bowel (12), duodenal biopsies from 39 patients with RAP were examined for the presence of inflammatory changes.

\subsection{Patients and Methods}

During a prospective study 106 children with RAP were investigated according to a standard protocol. Patients were diagnosed as having RAP if they were aged between 5.5 and 12 years; had had recument abdominal pain for at least six months; had had altacks of pain varying in severity, duration and frequency; and if their attacks were sometimes accompanied by paleness, nausea, and vomiting. These criteria are in accordance with those in the literature, first laid down by Apley $(1,2)$, except for the duration of the complaints, for which we felt that a six month period was more justifiable. All children referred to our outpatient clinics with $\mathrm{RAP}$ and those admitted to the paediatric ward, who met the inclusion criteria, were admitted to the study. All children were referted to us by their general practitioners or by school doctors. Both groups of colleagues were informed about the study. All parents gave informed consent. In only two cases did the parents refuse to take part.

The protocol consisted of a standard physical examination; routine laboratory investigations of blood, faeces and urine and a standard ultrasound examination. Lactose tolerance was tested with an oral lactose load of $2 \mathrm{~g} / \mathrm{kg}$ body weight, with a maximum of $50 \mathrm{~g}$. Breath samples were analyzed after 30 minutes intervals for two hours, with a Lactoscreen $^{\text {(i) }}$ (HoekLoos). Hydrogen content of breath samples was considered abnormal if it exceeded 20 ppm.

The "Cr-EDTA permeability test was perfonned as previously described (10). Briefly, 
after an ovemight fast, a dose of $100 \mu \mathrm{Cu}$ "Cr-EDTA was given orally in $10 \mathrm{ml}$ dilution of $5 \%$ glucose. Urine was collectud for 24 hours. Unine volumes were measured and two stumples of $5 \mathrm{mll}$ each were counted in a well-conter. A standard 1:100 dilution of $5 \mathrm{ml}$ was similarly counted. Radioactivity excreted in the urine over a period of 24 hours was expressed as a percentage of the oral dose. In a previous paper, our control group of children showed a mean "Cr-EDTA excretion of $2.5 \%$ (iwice $\mathrm{SD}$ : $1.3 \%$ )(13). We therefore chose a cut off value of $3.8 \%$ for the evaluation of the relationship between small bowel permeability and duodenal inflammatory changes.

\begin{tabular}{lll}
\hline & $\begin{array}{l}\text { Duodenal } \\
\text { Biopsy } \\
(n=39)\end{array}$ & $\begin{array}{l}\text { No Duodenal } \\
\text { Biopsy } \\
(n=67)\end{array}$ \\
\hline Sex (male/ female) & $15 / 24$ & $23 / 44^{*}$ \\
Mean age at entry (years) & 8.25 & $9.23^{*}$ \\
Range & $5.9-14$ & $5.5-12.4$ \\
Mean duration of complaints (months) & 26.8 & $19.4^{*}$ \\
Range & $6-120$ & $6-80$ \\
Mean frequency of attacks (times/week) & 4 & $3.9^{*}$ \\
Range & $1 /$ month- every day & $1 /$ month- every day \\
Mean duration of attacks (hours) & 6.3 & $5.3^{*}$ \\
Range & 5 min.- all day & 5 min- all day
\end{tabular}

No significant differences between groups (Wilcoxon test).

\section{Table 1:}

Clinical features of children with RAP

\begin{tabular}{llll}
\hline & $\begin{array}{l}\text { All patients } \\
\text { with RAP } \\
(n=100)\end{array}$ & $\begin{array}{l}\text { Duodenal } \\
\text { Biopsy } \\
(n=39)\end{array}$ & $\begin{array}{l}\text { No Duodenal } \\
\text { Biopsy } \\
(n=61)\end{array}$ \\
\hline $\begin{array}{lll}\text { Standard Error of Mean } \\
\text { Range }\end{array}$ & $\begin{array}{l}0.16 \\
1.1-10\end{array}$ & $\begin{array}{l}4.11 \% \\
0.26\end{array}$ & $\begin{array}{l}3.24 \% \\
0.19\end{array}$ \\
& $1.9-10$ & $1.1-8$
\end{tabular}

* No significant differences between groups (t-test).

\section{Table 2:}

Urinary ${ }^{s} \mathrm{Cr}$-EDTA evcretion in different patient groups 
Clinical details regarding our patients are shown in table 1 . Out of 106 patients with RAP, 39 underwent endoscopy and biopsy of the duodenum. Duodenal biopsy specimens were taken after an overnight fast from the proximal duodenum with an OYnupus GLF XP10 endoscope. All patients were sedated with domicum (midazolami) and atropin. One or two biopsy specimens from each patient were immediately placed in Bowin fixative. After embedding in paraffin they were cut into $4 \mu \mathrm{m}$ sections and stained with hematoxylin-eosin. The most representative, well oriented sections were used for grading. Histological grading of duodenal inflammation was done according to the criteria laid down by Whitehead at al (14). The histologic sections were examined by at pathologist, who had no knowledge of the clinical or endoscopic findings. All sections were reviewed for this study by the same observer (JWA).

Although a certain bias may have been introduced in the group of patients $(n=39)$ who underwent duodenal biopsy (37\% of the total study group), there appeared to be no significant differences between the two groups in regard to clinical data (table 1) or $\mathrm{CC}$ EDTA excretion (table 2). There was, however, a tendency towards higher "Cr-FDTA excretion values and a slightly longer duration of complaints in the group that underwent biopsy. Only the results concerning intestinal permeability and duodenal biopsy results are reported in the present paper.

\subsection{Results}

Of the 39 biopsied patients, $13(33 \%)$ showed microscopically obvious signs of inflammation (10 and 3 with Whitehead grade 2 and 3 respectively), 15 (38\%) showed minimal changes (grade 1), whereas in $11(28 \%)$ patients biopsies looked nomal (grade 0). A simultaneous antral biopsy was taken from 11 of these patients; in 8 cases $(73 \%)$ a Helicobacter pylori (H pylori) colonisation was detected on histologic examination (3 with a grade 0,1 with a grade 1,2 with a grade 2 and 2 with a gracle 3 duodenitis). Histologic evidence of gastritis was present in $4(50 \%)$ of the patients in whom $\mathrm{H}$ pylori was found. The combination gastritis and duodenitis was present in 3 of the 8 patients in whom H pylori was found. Results of 24-hours "Cr-EDTA excretion in all our 106 RAP patients ane presented in table 2 . In 6 cases either the parents refused the test or urine sampling failed.

\begin{tabular}{|c|c|c|c|c|c|}
\hline & \multicolumn{5}{|c|}{ Duodenitis Grade } \\
\hline & $\begin{array}{l}0 \\
(n=11)\end{array}$ & $\begin{array}{l}l \\
(n=15)\end{array}$ & $\begin{array}{l}2 \\
(n=10)\end{array}$ & $\begin{array}{l}3 \\
(n=3)\end{array}$ & $\begin{array}{l}1,2 \text { and } 3 \\
(n=28)\end{array}$ \\
\hline "Cr-EDTA excretion (\%) & 3.3 & $4.64^{\text {咩 }}$ & $4.34 \#$ & $3.67 \#$ & $4.42 *$ \\
\hline Standard Error of Mean & 0.27 & 0.49 & 0.53 & 0.59 & 0.33 \\
\hline Range & $1.9-4.7$ & $2.4-10$ & $2.3-7.5$ & $2.3-4.8$ & $2,3-10$ \\
\hline
\end{tabular}

All companed to grade $0: * \mathrm{p}<0.02$, ** $\mathrm{p}<0.05$, \# nol significant ( $\mathrm{t}-$ test)

\section{Table 3:}

Results of the "Cr-EDTA permeability test in 39 patients with RAP with varying degrees of duodenal inflammation. 
The mean :Cr-EDTA excretion values of patients with varying degrees of duodenal inflammation are shown in table 3 .

The ${ }^{\mathrm{C}} \mathrm{Cr}-\mathrm{EDTA}$ excretion of patients with grade 1 duodenal inflammation was significantly higher than that of patients with a grade $0(p<0.02$, Student's t-test). Most notably, no differences were found between patients with grade 2 or grade 3 on the one hand, and grade 0 on the other. The mean "Cr-EDTA excretion of patients with normal fundings (grale 0), however, was significantly lower than that of patients with grades 1,2 and 3 taken together $(p<0.05$, Student's l-test).

\begin{tabular}{llll}
\hline & "Cr-EDTA excretion (\%) & Total \\
\cline { 2 - 4 } & $\leq 3.8 \%$ & $>3.8 \%$ & \\
\hline Grade 0 & 9 & 2 & 11 \\
\hline Grade $1,2,3$ & 12 & 16 & 28 \\
\hline $\mathrm{p}=0.03$ (Fisher's test, single-tailed) & 18 & 39 \\
\hline
\end{tabular}

\section{Table 4: \\ Relationship between ${ }^{s} \mathrm{Cr}$-EDTA test results and duodenal inflammato- ry changes}

Table 4 shows the relationship between normal and abnomal small bowel "CI-EDTA excretion values and the histologic grading of the duodenal biopsy. It illustrates the significant relationship between abnormal small bowel permeability and inflammatory changes in the duodenum $(p=0,03$, Fisher's exact test).

\subsection{Discussion}

In a group of 66 children wilh RAP, Ament and Christie found duodenitis in only 2 cases and a duodenal ulcer in 8 , but these diagnoses were made endoscopically and not confinmed histologically (15). In a group of 62 children with RAP. Black et al described only 9 cases with signs of histologically confirmed duodenitis (16). They used a histologic grading system different from ours, however, which makes amparison benween the studies difficult. In a retrospective study of 320 gastroduodenoscopies in children, Oderda ef al reported only 32 cases with endoscopic signs of duodenal damage (17). Abdominal pain was the nost common symptom in 25 of these patients $(78 \%$ ) and the criteria of Whitehead et af for the histological diagnosis of duodenitis were met in only 4. It is renurkable that 3 of these patients had RAP. More recently, Glassman ef al (18), making use of Whitehead's criteria, reported duodenitis in $47 \%$ of 95 children with epigastric pain. The criteria of Whitehead et al are generally accepted for classifying inflammatory lesions in the duodenum. Grade 0 describes a normal histologic appearance. Grade 1 describes "minimal change" duodenitis, grade 2 and 3 are regarded as 
definitely abnomal, indicating the presence of duodenitis (14). The clinical significance of the classification is, however, questionable, as mimimal changes and even overt inflammation have been reported in healthy adult volunteers (19). Whether these observations are also applicable to children, is brought into doubt by the data of Oderda et al (17). In the present study, a third of the patients with RAP had definite signs of duodenitis: grade 2 and 3. Given the above reservations, this supports our hypothesis, that children with RAP have a high incidence of intestinal inflammation. Our results also show a significant relationship between intestinal permeability to "Cr-EDTA and inflammatory changes. The minimal intlammatory changes described as grade 1 are often regarded as still within the reference range. In this context, it is remarkable that in our group of patients with grade 1 the "Cr-EDTA excretion test yielded significantly higher results than in patients with nomal findings (grade 0). Separately, however, grade 2 or 3 patients show no significant differences from patients with grade 0 . This discrepancy may possibly be explained by the small number of patients in these two groups. This might shed new light on the relevance of grade I inflanmatory clanges and suggest that minimal inflammatory changes could be considered as abnormal being a precursor of full blown duodenitis. Altematively it might represent an early healing stage before abnomal small bowel permeability had retumed to normall. On the other hand, in those children in whom there was increased :Cr-EDTA excretion together with a normal histological appearance of the duodenum, we are possibly dealing with a false negative finding, as multiple biopsies specimens (which were not considered justifiable in this study), would be required to exclude the possibility of patchy lesions in the small bowel. When (for the above mentioned reasons), all patients with inflammatory changes (grades 1,2 and 3) are taken together, there appears to be a significant relationship between abnormal "Cr-EDTA excretion $(>3.8 \%$ ) and the presence of inflammatory changes in the duodenum of patients with RAP (table 3). On the basis of these numbers,

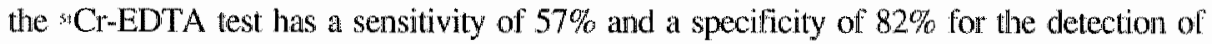
duodenitis. Despite the apparently low sensitivity of the "Cr-EDTA test, it still shows a positive predictive value of $89 \%$. Used in this way the "Cr-EDTA permeability test may be a valuable diagnostic tool in children with RAP, in screening for possible intestinal inflammatory changes. We centainly use it in clinical practice to find out if we are dealing with a possibly somatic cause of the abdominal complaints; this we believe is justified by our findings in the present study.

The cause of the inflanmatory changes in our patients still remains unclear. Recent studies, (Presented in a poster session at the first meeting of the European Campylobucter study group, Bordeaux, France, october 1988) by de Rafael ot al and Mahony et al showed that campylobacter (now called Helicobacter pylori) was present in the antral mucosa of children with chronic gastritis and RAP. H pylori has, however, an affinity for gastric mucosa (20). Unfortunately, gastric biopsies were not obtained from all patients in the present study. Glassman et al reported the presence of duodenitis without associated gastritis in $47 \%$ of their $H$ pylori negative patients, whereas duodenitis associated with gastritis was found in $56.3 \%$ of their $H$ positive palients (18). In our 8 patients with grade 2 or 3 duodenitis and $\mathrm{H}$ pylori colonisation, 3 (37\%) showed associated gastritis microscopically. Furthermore, small bowel permeability to "CrEDTA is abnormal in children with gastroenteritis (13), a condition known to be associated with duodenal mucosal inflammation (21). Although we have only few data to suppont this contention, it seems likely that the inflammatory changes we found in our patients were in some cases caused by bacterial or wiral infections. Food hypersensilivity 
might also have a pole in causing inflammation of the small bowel. Either a primary (food antigens), or a secondary (bacterial antigens) hypersensitivity reaction could result in a locall intestinal inflammation whereby the intestinal wall could loose its ability to act as an effective barrier. The altered intestinal permeability would then allow for the passage of more macromolecular antigens. This penetration of antigens could further aggravate the local hypersensitivity reaction, which would in the end result in widespread inflammatory changes and causes damage and disease $(22,23)$. Some authors found a correlation berween the irritable bowel syndrome and hypersensitivity to food $(24,25$, 26). The symptomatology and pathofysiology in the irritable bowel syndrome seem closely related to RAP in childhood (27). The findings in our patients and data of other authors seem to support the hypothesis that food hypersensitivity might play a part in RAP.

Further studies are needed to elucidate the parhophysiological mechanisms involved in RAP patients. It seems likely, however, that small bowel inflammation primary or secondary to different environmental factors, may play an important part in the pathogenesis of this frequently misunderstood problem in childhood. 


\subsection{References}

(1): Apley J and Naish N. Recurrent Abdominal Pains: a ficld survey of 1000 school children. Arch Dis Childhood 1958; 33; 165 - 170

(2): Apley J. The Child with Abdominal Pains, $2^{\text {ad }}$ edition. Oxford, Blackwell Scientific Publications, 1975.

(3): Barr G, Levine DL and Watkins JB. Recurrent Abdominal Pain of Childhood due to lactose intolerance. New Engl J Med 1979; 26: $1449-1452$

(4): Piñeiro- Carrero VM, Andres JM, Davis RH and Mathias JR. Abnormal gastroduodenal motility in children and adolescents with recurrent functional abdominal pain. J Pediatr 1988; 5; $820-825$

(5): Schisgall RM. Radiographic features of appendiceal colic in children. Pediatr Radiol 1986; 16: $392-399$

(6): Friedman R. Some characteristics of children with "psychogenic" pain: observations on prognosis and treatment. Clin Pediatr 1972; 1: 331 - 333

(7): Maddison TG. Recurrent abdominal pain in children. Med J Aust 1977; i: 708 710

(8): MoGrath PJ, Goodman JT, Firestone P, Shipman R and Peters S. Recurrent Abdominal Pain: a psychogenic disorder ? Arch Dis Childhood 1983; 58: 888 - 890 (9): Raymer $\mathbb{D}$, Weininger $\mathrm{O}$ and Hamilton JR. Psychological problems in children with abdominal pain. Lancet 1984; i: 439 - 440

(10): van der Meer SB, Forget PP and Heidendal GAK. Small bowel permeability to s.Cr-EDTA in children with recurrent abdominal pain. Acta Paed Scand 1990; 79: $422-426$

(I I): Bjamason I, Peters TJ and Veall N. A persistent defect in intestinal permeability in celiac disease demonstrated by a "Cr-labelled EDTA absorption test. Lancet 1983 ; i: $323-325$

(12): Bjamason I, O'Morian C, Levi AJ and Peters TJ. Absorption of suChromium labelled Ethylenediaminetetraacetate in Inflammatory Bowel Disease. Gastroenlero$\log y 1983 ; 85: 318-322$

(13): Forget PP, Sodoyez-Goffaux F and Zapitelli A. Permeability of the small intestine to "Cr-EDTA in children with acute gastroenteritis or eczema. If Pediatl" Gastroenterol Nutr 1985; 4:393-396

(14): Whitehead R, Roca M, Meikle DD, Skinner J and Truelove. The histological classification of duodenitis in fibreoptic biopsy specimens. Digestion 1975; 13: $129-$ 136

(15): Ament ME and Christie DL. Upper gastrointestinal fiberoptic endoscopy in pediatric patients. Gastroenterology 1977; 72:1244 - 1248

(16): Black DD, Haggitt RC and Whitington PF. Gastroduodenal endoscopic-

histologic correlation in pediatric patients. J Pediatr Gastroenterol Nutr 1988; $7: 353$ $-358$

(17): Oderda G, Fomi M, Farina L, Dell'Olio D and Ansaldi N. Duodenitis in children: clinical, endoscopic and pathological aspects. Gastrointest Endosc 1987; 33: $366-369$

(18): Glassman MS, Schwarz SM, Medow MS, Beneck D, Hallata M, Berezin S and Newman LJ. Campylobacter pylori-related gastrointestinal disease in children.

Incidence and clinical findings. Dig Dis Sci 1989; 34: 1501 - 1504

(19): Kreuning J, Bosman FT, Kuiper G, vd Wal AM and Lindeman J. Gastric and 
duodenal mucosa in "healthy" individuals. I Clin Path 1978; $31 ; 69-77$

(20): Elta $\mathrm{G}$, Kern $\mathrm{S}$, Nostrant $\mathrm{T}$ and Appleman H. Campylobacter-like organisms in erosive gastroduodenitis. Gastroenterology $1987 ; 92: 1382$

(21): Barnes GL and Townley RW. Duodenal nucosal damage in 31 infants with gastroenterits. Arch Dis Childhood 1973; 48: 343 - 349

(22): Shorter RG, Huizenga $\mathrm{KA}$ and Spencer RJ. A working hypothesis for the etology and pathogenesis of non-specific inflammatory bowel disease. Am J Dig Dis $1972 ; 17: 1024-1032$

(23): Ramage JK, Stanisz A, Scicchitano R, Hunt RH and Perdue MH. Effect of immunologic Reactions on Rat Intestinal Epithelium. Gastroenterol, 1988; 94: 1368 1375

(24): Petitpierre M, Gumowski P and Girard JP. Imitable Bowel syndrome and Hypersensitivity to food. Ann Allergy 1985; 54:538 - 540

(25): Alun Jones V, Shorthouse M, McLaughlan P et al. Food intolerance: a major factor in the pathogenesis of irritable bowel syndrome. Lancet 1982; 2: 1115 - 1117 (26): Nanda $R$, James $R$, Smith H, Dudley CRK and Jewell DP. Food intolerance and the irritable bowel syndrome. Gut 1989; 30: 1099 - 1104

(27): Dotewall G, Svedlund J, Ssjodin I. Symptoms in irritable bowel syndrome. Scand J Gastroenterol 1982; 17: suppl. 79: $16-19$ 


\section{Gastroesophageal Reflux and Recurrent Abdominal Pain}

S.B. van der Meer, P.P. Forget, R.H. Kuijten, J.W. Arends

\section{Summary}

In this study we looked for the presence of gastroesophageal reflux in children with recurrent abdominal pain and its possible relationship to food intolerance associated duodenal inflammation. Twenty-four hour intra-oesophageal $\mathrm{pH}$-monitoring, an endoscopic duodenal biopsy and a small bowel " $\mathrm{C}_{\mathrm{r}}$-EDTA permeability test were performed in 25 children with recurrent abdominal pain. In 14 cases $(56 \%)$ the pH-monitoring was abnormal, pointing to the presence of pathological gastroesophageal reflux. Unblinded treatment of gastroesophageal reflux in the latter patients resulted in resolution or improvement of abdominal pain in 10 cases $(71 \%$ ). Gastroesophageal reflux did not appear to be associated with either intestinal permeability to "Cr-EDTA or duodenal biopsy findings. We conclude that pathological gastroesophageal reflux is a frequent finding in children with recurrent abdominal pain, that it is unrelated to duodenal inflammation and that there might be at causal relationship between pathological gastroesophageal reflux and recurrent abdominal pain in children.

(Acta Paediatrica Scandinavica 1991; in press) 


\subsection{Introduction}

Gastroessophageal reflux (GER) is known to be an important cause of chronic respiratory disease in childhood $(1,2)$. Not only on the basis of pulmonary aspiration, but also on the basis of reflux-induced reflex bronchospasms (3). Alternatively, respiratory disease could cause GER (4). Furthermore, GER has been reported to play a significant role in causing central apnea with reflex bradycardia, which might lead to sudden infant death (5). Several gastrointestinal diseases are known to be associated with GER as well. In adult patients with non-ulcer dyspepsia, Talley and Piper (6) found GER in 22\% of the subjects studied and initable bowel syndrome in $23 \%$. Most notably, $19 \%$ had both GER and irritable bowel syndrome. In a study of 25 adult patients with the irritable bowel syndrome, Smart et al (7) reported the presence of GER in $50 \%$ of their patients. Furthermore, food intolerance (8) and more specifically, cow's milk intolerance (9) have also been reported to be associated with GER. Finally, there have been several reports on the association between food intolerance and the irritable bowel syndrome $(10,11)$. We previously reported the presence of abnormal small bowel permeability and duodenal inflammation in children with recurrent abdominal pain (RAP) $(12,13)$. We suggested food intolerance as a possible cause of these abnormalities. On the basis of the above mentioned observations, there seerns to be a link between the presence of GER, the irritable bowel syndrome and food intolerance. Moreover, the symptomatology of the adult irrilable bowel syndrome and the recurrent abdominal pain (RAP) syndrome in children, seem closely related (14). Strangely enough, there have been no reports in children on the possible association between RAP and GER. Therefore, the aim of the present study was to investigate the presence of GER in children with RAP and to look for a possible relationship between GER, abnormal small bowel permeability and duodenal inflammation as the latter might indicate the presence of food intolerance in these patients.

\subsection{Patients and Methods}

During a prospective study on RAP, 27 patients underwent a 24 -hour intra-oesophageal pH-monitoring. All patients met the inclusion criteria laid down at the beginning of the situdy:

1). age range 5.5 to 12 years,

2). a minimum of six months of recurrent abdominal pain of unknown origin,

3). attacks of pain varying in severity, duration and frequency,

4). sometimes accompanied by vegetative symptoms such as paleness, nausea and vomiting.All children referred to our outpatient clinics, and those admitted to the pediatric ward, meeting this inclusion criteria, were consecutively included in the study. All parents gave informed consent. The protocol consisted of a thorough physical examination, routine laboratory investigations of blood, faeces and urine and a standardized ultrasound examination of the abdomen. Lactose tolerance was tested with an oral lactose load of $2 \mathrm{~g} / \mathrm{kg}$ body weight, with a maximum of $50 \mathrm{~g}$. Breath samples were analyzed at 30 minutes intervals up to two hours, using a Lactoscreen (HoekLoos). Hydrogen content values of breath samples were considered abnomal when exceeding $20 \mathrm{ppm}$.

Intestinal permeability was investigated, making use of "chromium labelled ethylenedia- 
minetetracetate ("Cr-EDTA). The "Cr-EDTA permeability test was performed as previously described (13). Briefly: after an ovemight fast, $100 \mu \mathrm{Cu}$ "CT-EDTA were given orally in $10 \mathrm{ml}$ dilution of $5 \%$ glucose. Unine was collected for 24 hours Urine volumes were measured and two samples of $5 \mathrm{ml}$ each wene counted in a wellicounter. A standard 1:100 dilution of $5 \mathrm{ml}$ was similarly counted. Radioactivity excreted in the urine over a period of 24 hours was expressed as a percentage of the oral dose.

The day after the pH-monitoring was perfomed, duodenal biopsies were taken after an overnight fast from the proximal duodenum with an Olympus GIF XP10 endoscope. All patients were sedated with dormicum (midazolam) and atropin. One or two biopsy specimens from each patient were immediately placed in Boun fixative. After paraffin embedding they were sectioned at a thickness of 4 micrometer and stained with hematoxylin-eosin. The most representative, well oriented sections were used for grading. Histologic grading of duodenal inflammation was performed according to the criteria laid down by Whitehead et al (15). The histologic sections were examined by a pathologist, who had no previous knowledge of the clinical and endoscopic findings. All sections were reviewed for this study by the same observer (JWA).

Twenty four hour oesophageal pH-monitoring was carried out with an antimony $\mathrm{pH}$ catheter with a skin reference electrode. The catheter was calibrated in $\mathrm{pH} 4$ and $\mathrm{pH} 7$ buffer solutions, before and after monitoring. The catheter was introduced into the esophagus transnasally and placed $4 \mathrm{~cm}$ above the lower esophageal sphincter, making use of oesophageal length formulas as reported by Strobel et al (16). During pHmonitoring the children were free to play and diet was unrestricted. "The position of the child (supine, prone) was noted in a diary, by a nurse or the child, as was the time of sleeping. pH-monitoring was regarded as abnormat when the time during which the $\mathrm{pH}$ was lower than 4 , exceeded $5 \%$ of total monitoring time (17). Only results concening $\mathrm{pH}$-monitoring, endoscopic findings and intestinal permeability tests are reported in the present paper.

\subsection{Results}

In 27 cases a 24-hour pH-rnonitoring was performed. In 2 cases monitoring failed due to technical problems. In 11 cases (44\%) no abonomalities were found In 14 cases (56\%) the pH-monitoring was abnomal, pointing to pathological GER. Patients wilth GER

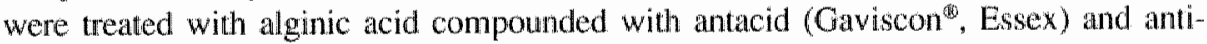
trendelenburg position during sleep. In 8 of the latter cases (57\%) the abdominal pain resolved completely, in 2 cases $(14 \%)$ the abdominal pain improved, in 2 cases (1.4\%) the abdominal pain was unchanged, in 1 case it resolved spontaneously. In 1 case the outcome is unknown, since the patient was lost to follow-up. These findings are summarized in table 1. The clinical symptoms of our patients with abnormal $\mathrm{pH}$ monitoring were restricted to abdominal pain. Only two patients complained of frequent regurgitations, whereas $\mathbb{1}$ patient was suffering from recurrent respiratory infections. All other symptoms of GER, such as retrostemal pain, womiting and water brash, were not present. The localization of the abdominal pain was periumbilical in $65 \%$ of the patients, whereas only $25 \%$ complained of upper abdominal pain. In $10 \%$ of the patients the localization of the abclominal pain was ejther diffuse or unknown.

In the group of 14 patients with normal pH-monitoring, the abdominal pain resolved after appropriate treatment in 3 cases (27\%), one patient with Crohns disease, one patient with 


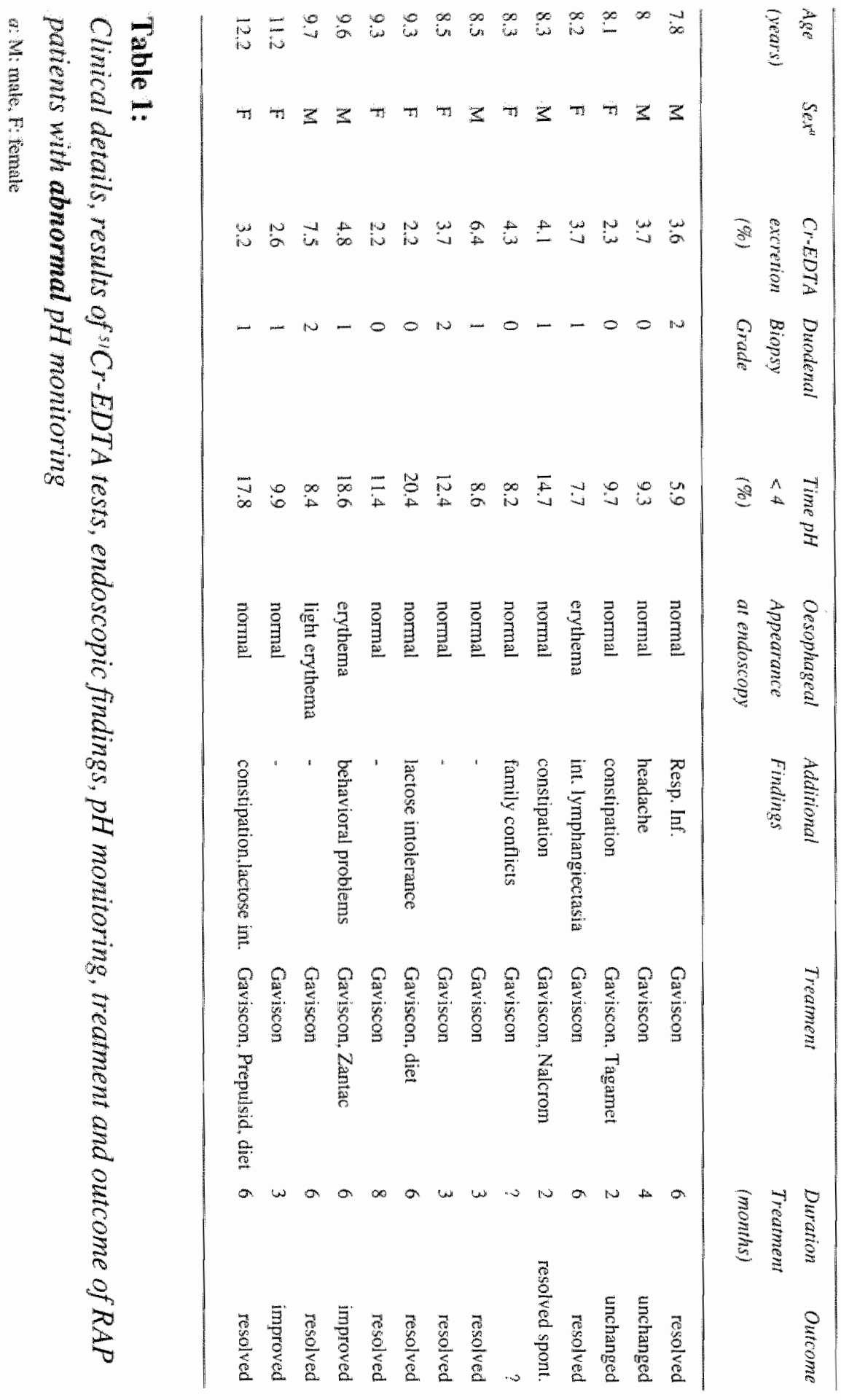




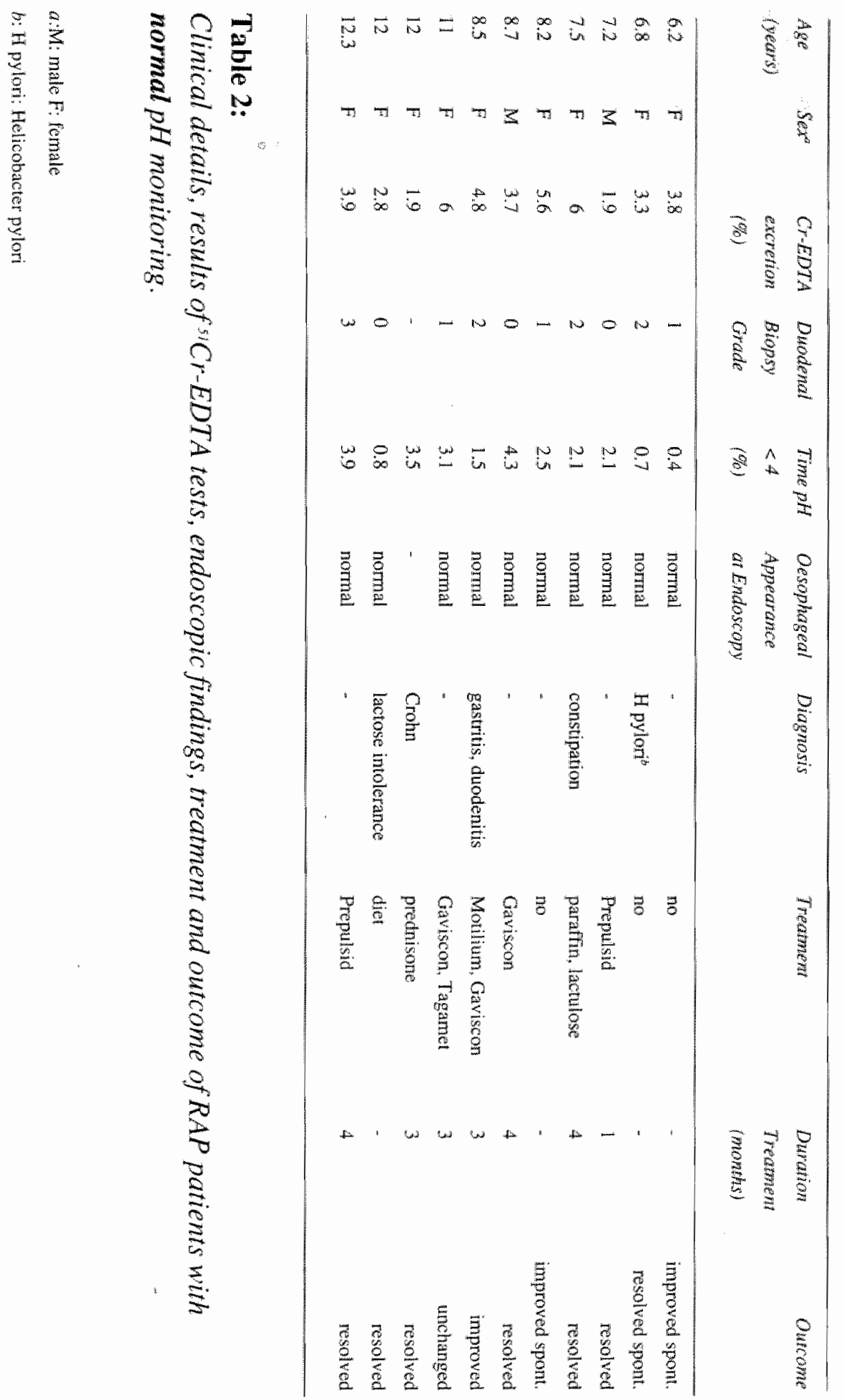


lactose intolerance and one patient with constipation. The abdominal pain improved in 1 case $(9 \%)$, patient with gastritis and duodenitis. In 2 parients (18\%) treated with Prepulside, a prokinetic drug, the abdominal pain resolved as well. In 3 cases $(27 \%), 2$ Without a specific diagnosis, the abdominal pain improved or resolved spontaneously, one of these patients had a positive Helicobacter pylori serology (ELISA). One patient with a slightly abnomal pH monitoring (time during which $\mathrm{pH}<4: 4.3 \%$ ) was treated with Gaviscon(1). The abdominal pain resolved completely. In one patient no change in the complaints was observed. These findings are summarized in table 2 .

The endoscopic aspect of the esophagus was normal in the majority of patients (1) out of 14). Esophageal biopsies were not obtained. Duodenal biopsies in patients with GER showed a Whitehead grade 0 in 5 , grade 1 in 6 and grade 2 in 3 cases. In the group of patients with normal findings during $\mathrm{pH}$-monitoring, duodenal biopsies showed a Whitehead grade 0 in 3 , grade $\|$ in 3 , grade 2 in 3 and grade 3 in one case. No relationship was found between dwodenitis score and $\mathrm{pH}$ monitoring results.

The mean urinary ${ }^{\text {C }} \mathrm{Cr}-\mathrm{EDT} A$ excretion in the patient group with GER was $3.88 \%$ (SD: $1.54 \%$ ). In the group of patients with nomal $\mathrm{pH}$-monitoring findings, the mean urinary :Cr-EDTA excretion was $3.97 \%$ (SD: 1.49\%). The difference between the mean urinary excretion of "Cr-EDTA in the patients with GER and the patients with a normal pH monitoring was not significant.

\subsection{Discussion}

Previous findings in our study on RAP in children pointed in the direction of a possible enteral origin in these patients complaints. We found an abnormal intestinal permeability to "Cr-EDTA in children with RAP (chapter 3) (12) ass well as the presence of duodenitis in $33 \%$ of our patients who underwent an endoscopic duodenal biopsy (chapter 4$)(13)$. As an increased intestinal permeability to $\mathrm{Cr}$-EDTA has been shown to be present in some patients with food allergy (18), and patients with gastroenteritis (19), we suggested viral or bacterial infections or food allergy as possible causes of the duodenitis. However, we found no firm data supporting this hypothesis. Because of the reported evidence of GER in patients with non-ulcer dyspepsia and the irritable bowel syndrome $(6,7)$ and the resemblance in symptomatology between these entities and RAP in children (14), the presence of GER needed to be investigated in our patients with RAP. On the other hand, a possible relationship might be found between GER and the, so far unexplained, small bowel inflammatory changes we found in our group of patients with RAP. Our results indicate that in a high percentage (56\%) of RAP patients an abnormal pH-monitoring, pointing to the presence of pathological GER, can be observed. The two main questions that ane raised by this observation are: firstly, could the abnomal pH monitoring in these children be linked to lood intolerance associated duodenal inflammatory changes and secondly could there be a causal relationship between GER and RAP in children ?

The evidence we found for an inflammatory enteropathy in our RAP patients (chapter 3 and 4$)(12,13)$, did not appear to be related to the presence of an abnormal $\mathrm{pH}$ monitoring. Small bowel permeability to "Cr-EDTA in both groups, with and without GER, did not differ significantly and duodenal biopsy findings in the patients with a nomal pH-monitoring, were practically similar to those of patients with an abnormal $\mathrm{pH}$ monitoring. Furthermore, treatment of the pathological GER with an antacid such as Gaviscon appeared to be effective in the majority of patients. Given these three 
observations, it is unlikely that pathological GER is related to or caused by food intolerance and duodenal inflammation.

Another possible explanation for the presence of pathological GER in children with RAP might be alterations in gastroduodenal motility. Abnomal gastroduodenal motility has been reported to be present in children with RAP (20). Motility studies in children ws well as in adults with GER have shown the presence of disorders of esophageal peristalis (21, 22). Recently, Cucchiara et al (23) reported on the pathophysiological nechanisms of GER and distal esophageal motility in children. They concluded that most reflux episodes in children with GER were due to an inappropniate transient lower esophageal. sphincter relaxation. The presence of pathological GER in chilinen with RAP might be caused by an underlying intestinal motility disturbance leading to an inappropriate relaxation of the lower oesophageal sphincter.

Whether pathological GER could cause RAP in children needs to be studied in more detail. Treatment of the pathological GER resulted in resolution or improvement of the abdominal pain in many patients (71\%). During follow-up, these patients remained free of abdominal pain after a mean follow-up of at lesst 6 month after treatment. However, treatment was uncontrolled and unblinded making interpretation of our results difficult. In a study of 360 adult patients with dyspepsia, Horrocks et al (24) reported on the effect of antacids in different patient groups. Relief of pain by antacids in patients with gastric or duodenal ulcers was 39 and $36 \%$ respectivelly, whereas the relief of pan in the patients with "functional" complaints was as high as $26 \%$. Compared to these results, a strictly placebo effect of the antacids in our patients seems highly unlikely. Nevertheless, the possible causal relationship between RAP in children and pathological GER, still remains open to discussion. A double blind therapeutical trial would be necessary to confirm this relationship.

We have shown that GER is a frequent finding in children with RAP, and that with appropriate treatment the abdominal pain resolves in most of them. Most notably, the clinical symptomatology of GER in this patient group seems to be absent, which makes recognition of the disorder difficult. A proper investigation by means of a 24 hour intraesophageal monitoring is mandatory. Futhermore, the endoscopic findings in these patients are of no help, as oesophagitis was rarely observed in the present study. Further studies are in progress in order to elucidate the nature of the observed association between GER and RAP in children. 


\subsection{References}

(1): Danub $\mathrm{O}_{\text {, Casar }} \mathrm{C}$, Larrain $\mathrm{A}$. Pope $\mathrm{CE}$. Esophageal refux: an unrecognized cause of recunrent obstuctive bronchits in children. II Pediatr 1976:89:220-224

(2): Hoyoux C, Forget PP, Lambrechts L, Geubelle F. Chronic bronchopulmonary disease and gestroesophageal reflux in children. Pediatr Pulmonol 1985; 1: 149-153

(3): Spaulding HS, Mansfield LE, Stein MR, Sellner JC, Gremilion DE. Further investigation of the association between gastroesophageal reflux and bronchoconstriction. I Allergy Clin Immunol 1982; 69: 516-521

(4): Hrabovsiky EE, Mullett MD. Gastroesophageal reflux and the premature infant. J Pediatr Surg 1986; 21: 583-587

(5): Kenigsberg K., Griswold PG, Buckley BJ, Gootman N, Gooman PM. Cardiac effects of esophageal stimulation: possible relationship between gastro-esophageal reflux (GER) and sudden infant death syndrome (SIDS). J Pediatr Surg 1983; 18:542545

(6): Talley NJ, Piper DW. The association between non-ulcer dyspepsia and other gastrointestinal disorders. Scand I Gastroenterol 1985; 20:896-900

(7): Smart HL, Nicholson DA, Atkinson M. Gastro-oesophageal reflux in the irritable bowel syndrome. Gut 1986;27: 1127-1131

(8): Heiner DC. Respiratory disease and food allergy. Ann Allergy 1984; 53: 657-664

(9): Forget PP, Arends JW. Cow's milk protein allergy and gastro-oesophageal reflux.

Eur J Pediatr 1985; 144: 298-300

(10): Alun Jones V, Shorthouse M, McLaughlan P et al. Food intolerance: a major factor in the pathogenesis of irritable bowel syndrome. Lancet 1982; 2: 1115 - 1117

(11): Nanda R, James R, Smith H., Dudley CRK and Jewell DP. Food intolerance and the irritable bowel syndrome. Gut 1989; 30: 1099 - 1104

(12): van der Meer SB, Forget PP and Heidendal GAK. Small bowel permeability to "CEDTA in children with recument abdominal pain. Acta Paed Scand 1990; 79; 422 - 426. (13): van der Meer SB, Forget PP and Arends JW. Abnormal small bowel permeability and duodenitis in recurrent abdominal pain. Arch Dis Child 1990; 65: 1311 - 1314.

(14): Dotevall G, Svedlund J, Ssjodin I. Symptoms in irritable bowel syndrome. Scand J Gastroenterol 1982; 17: suppl. 79:16-19

(15): Whitehead R, Roca M, Meikle DD, Skinner I, Truelove SC. The histological classification of duodenitis in fibreoptic biopsy specimens. Digestion 1975; 13: 129 136

(16): Strobel CT, Byrne WJ, Ament ME, Euler AR. Correlation of esophageal lengths in children with heights: Application to the tutile test without prior esophageal manometry. J Pediatr 1979; 94: 81-84

(17): Vandenplas Y, Sacre-Smits L. Continuous pH monitoring in 285 asymptomatic infants 0 - 15 months old. J Pediatr Gastroenterol Nutr 1987; 6: 220-224

(18): Scadding S, Bjamasson I, Brostoff J, Levi JA, Peters FJ. Intestinal permeability to :Cr-labelled ethylenediaminetetracetate in food intolerant subjects. Digestion 1989; 42: $104-109$

(19); Forget PP, Sodoyez-Goffaux $\mathrm{F}$ and Zappitelli A. Permeability of the small bowel intestine to $\mathrm{Cr}$-EDTA in children with acute gastroenteritis or eczena. $J$ Pediatr Gastrocnterol Nutr 1985; 4: 393-396.

(20): Piñeiro-Camero VM, Andres JM, Davis RH, Mathias JR. Abnomal gastroduode-

nal motility in children and adolescents with recurrent functional abdominal pain. J 
Pediatr 1988; 113: $820-825$

(21): Hillemeier AC, Grill BB, McCallum R, Gryboski J. Esophageal and gastric motor abnormalities in gastro-esophageal reflux during infancy. Gastroenterology 1983; 84: $741-746$.

(22): Cucchiara S, Staiano A, Di Lorenzo C et al. Esophageal notor abnomnalities in children with gastro-esophageal reflux and peptic esophagitis. I Pediatr 1986; 108: 907 -910 .

(23): Cucchiara S, Staiano A, Di Lorenzo C, De Luca G, della Rocca A, Auricchio S. Pathophysiology of gastroesophageal reflux and distal esophageal motility in children with gastroesophageal reflux disease. J Pediatr Gastroenterol Nutr 1988; 7: $830-836$. (24): Horrocks IC, De Dombal FT. Clinical presentation of patients with "dyspepsia", detailed symptomatic study of 360 patients. Gut 1978; 19: $19-26$. 


\section{The Prevalence of Helicobacter pylori Serum Antibodies in Recurrent Abdominal Pain}

S.B. van der Meer, P.P. Forget, R.J.L.F. Loffeld, E. Stobberingh, R.H. Kuijten, J.W. Arends

\section{Summary}

As part of a large, prospective study on Recurrent Abdlominal Pain (RAP) in children we investigated the prevalence of Helicobacter pylori serum antibodies in these patients. Patients ages ranged from 6 to 12 years. They all suffered from Recurrent bouts of Abdominal Pain for a minimum of 6 months. H pylori antibodies were detected using an enzyme-linked immunosorbent assay (ELISA) for detection of $\operatorname{lgG}$ antibodies against $\mathrm{H}$ pylori. The prevalence of $\mathrm{H}$ pylori antibodies in the RAP group was compared to that of an age-matched control group, which predominantly consisted of pre-operative children. None of the control group suffered or hat suffered from RAP. Out of 82 RAP patients $7(8.5 \%)$ demonstrated Optical Density values above the cut-off point, therefore indicating the presence of antibodies to $\mathrm{H}$ pylori, whereas this was the case for $2(5.1 \%)$ out of 39 control children. We conclude that past or present stigmas of $\mathrm{H}$ pylori infection as measured by serology is similar in RAP and control children. Therefore, in our opinion $\mathrm{H}$ pylori does not appear to play a major role in RAP in children.

(submitted for publication) 


\subsection{Introduction}

Ever since the studies performed by Apley and co-workers in 1958 and later years $(1,2)$ on the subject of Recurrent Abdominal Pain (RAP) in children there has been considerable debate in the literature about different etiologic factors possibly platying a role in this puzzling syndronie $(3,4,5)$. Unequivocal somatic causes were scarcely reported $(6$, 7) and psychogenic mechanisms were considered to be the main cause in these patients complaints (8). Probably because psychogenic causes are difficult to point out $(9)$, the search for somatic causes in the meantime remained intriguing and recently gained interest. The discovery of Helicobacter pylori ( $\mathrm{H}$ pylori) and its establishment as an important organism in gastrointestimal disease in adults prompted studies on the role of H pylori in the pediatric age group. It is now clear that $H$ pylori does play a role in several gastrointestinal diseases in children, such as antral gastritis and peptic ulcer disease $(10$, 11). However, the role of $\mathrm{H}$ pylori is not yet clear in less well-defined and chronic disorders such as the RAP syndrome. In their retrospective study of 53 antral biopsies for the presence of $\mathrm{H}$ pylori, Drumm et al $(10)$ mention 24 children with abdominal pain as part of the study group. Unfortunately, they do not give more clinical details concerning their patients. Killbridge et al (11) retrospectively examined antral biopsies of 98 children and found chronic gastritis in 40 patients $22(55 \%)$ showing $\mathrm{H}$ pylori on the gastric surface. The complaints presented by $20(91 \%)$ of these patients was abdominal pain. Again, however, a more detailed clinical description is lacking. So it is questionable, whether the patient groups of the above mentioned studies met the criteria for a diagnosis of RAP. Therefore, clear data on a possible role of $\mathrm{H}$ pylori infections in RAP patients are not yet available in the literature. In order to assess the prevalence of H pylori serum antibodies in a group of representative and well-defined RAP patients we determined $\mathrm{H}$ pylori antibodies by means of an Enzyme-Linked Immunosorbent Assay (ELISA) among a group of schoolchildren with RAP and an age-matched control group.

\subsection{Patients and methods}

All RAP patients entering the study met the following criteria:

1). age range 5.5 to 12 years,

2). a minimum of six months of Recurrent Abdominal Pain of unknown origin,

3). attacks of pain varying in severity, duration and frequency,

4). sometimes accompanied by vegetative symptoms like paleness, natusea or vomiting. The patient group consisted of 28 boys and 54 girls, mean age 10.8 years. They followed a standard protocol consisting of routine laboratory investigations of blood, urine and stools. Additionally, an ultrasound examination of the abdomen, a small bowel permeato bility test and a lactose breath hydrogen test were performed. Finally, all patients were seen by a psychologist, who performed a variety of psychological tests. Results of these studies have been published separately (chapter 3,4 and 7) (12, 13, 14). The control group for this part of the study consisted of 39 children, 25 boys and 14 girls, mean age 6.6 years. They were mainly pre-operative children (eat-nose-throat procedures, fractures, retentio testis) or children attending the outpatient clinics for other than gastrointestinal diseases (epilepsy, asthma, short stature). All parents of both RAP and control group gave informed consent. Atopy, gastrointestinal symptoms and abdominal pain were not 
present in aryy of the control children. Blood samples were analyzed, using an IgG enzymemlinked immuno assay (ELISA) as previously described (15). In short: strains of H pylori were grown on a blood agar. The colonies of organisms were harvested, killed, sonicated and preserved with $0.1 \%$ sodium-azide. Microtitre plates were precoated with 100 ul of carbonate buffered bacterial antigen and kept at 4 .C for $8-10 \mathrm{~h}$. After washing with phosphate buffered saline (PBS), $100 \mu$ of $1 \%$ bovine albumin in PBS was added, kept for $2 \mathrm{ht}$ and washed again with PBS, then stored at 4 C. The test assay was performed with $50 \mu \mathrm{l}$ of PBS diluted serum, added to test and control wells. After incubation at 37 $\mathrm{C}$ and washing with $\mathrm{PBS}, 50 \mu$ of IgCi-specific peroxidase-conjugated rabbit antihuman immunoglobulin was added to the wells. After additional incubation for 90 minutes and washing, a color indicator was added followed by final incubation at room temperature for 30 minutes in the dark. The color reaction was stopped with sulphiric acid, read at 492 rim and expressed as optical density (OD). Control sera and blanks were included in each assay. The cut-off value, discriminating between positive and negative titers, was calculated at an OD of 1.40 .

For statistical analysis the Fisher test was employed.

\subsection{Results}

In the RAP group 7 patients $(8.5 \%$ ) showed an OD above the cut-off point of $1.40 \mathrm{OD}$, pointing to the presence of $\mathrm{H}$ pylori antibodies. Their mean value of OD was 2.95 (SD: 1.14), whereas the rest of the RAP group demonstrated a mean OD of 0.56 (SD: 0.27). More clinical details of the patients with a $\mathbb{H}$ pylori positive titer are shown in table 1 . The 3 patients that were treated with Bismuth subcitrate (25 $\mathrm{mg} / \mathrm{kg}$ for 6 weeks) and Tinnidazole ( $8 \mathrm{mg} / \mathrm{kg}$ for 10 days) are at present free of complaints.

$\begin{array}{lllll}\text { Pat Age Sex } & \text { Duration of Additional OD } & \text { Treatment } & \text { Outcone } \\ m \text { (years) } & \text { complains } & \text { findings } & & \end{array}$

\begin{tabular}{|c|c|c|c|c|c|c|c|}
\hline 1 & 9.7 & $\mathrm{~F}$ & 12 & None & 2.44 & None & Resolved spont. \\
\hline 2 & 9 & $\mathrm{~F}$ & 6 & None & 2.83 & None & Resolved spont. \\
\hline 3 & 9.4 & $\mathrm{~F}$ & 6 & Constipation & 1.43 & $\begin{array}{l}\text { Bismuth, } \\
\text { Tinnidazol }\end{array}$ & Resolved \\
\hline 4 & 11 & $\mathrm{M}$ & 6 & Gastritis & 3.74 & $\begin{array}{l}\text { Bismuth, } \\
\text { Timnidazol }\end{array}$ & Resolved \\
\hline 5 & 6.8 & $M$ & 8 & None & 2.32 & $\begin{array}{l}\text { Bismuth, } \\
\text { Timnidazol }\end{array}$ & Resolved \\
\hline 6 & 12 & $\mathrm{~F}$ & 24 & Gastritis & 2.89 & Antacids & Relapse \\
\hline 7 & 8.7 & $\mathrm{~F}$ & 12 & None & 5.02 & None & Resolved spont. \\
\hline
\end{tabular}

": M: male, F: fenale

\#: Optical Density

\section{Table 1:}

Clinical details of the Helicobacter pylori seropositive RAP patients 
In 3 patients the complaints resolved spontaneously, whereas I patient had a relapse of her complaints. Patient number 4 and 6 also underwent upper gastrointestinal endoscopy with biopsies taken from the antrum. Both biopsies showed $\mathrm{H}$ pylori at histologic examination. In all 7 patients no other plausible explanation was found for the abdominal pain i.e. no other abnomalities were discovered through additional investigations.

In the control group, 2 individuals $(5.1 \%)$ with an OD above 1.40 were observed: 1.47 and 1.81 respectively. The other part of the control group showed a mean OD of 0.57 (SD: 0.29). The difference between the prevalance of $\mathrm{H}$ pylori antibodies among the RAP group compared to the control group was not significant. The observed OD values in both study groups are summarized in figure 1 .

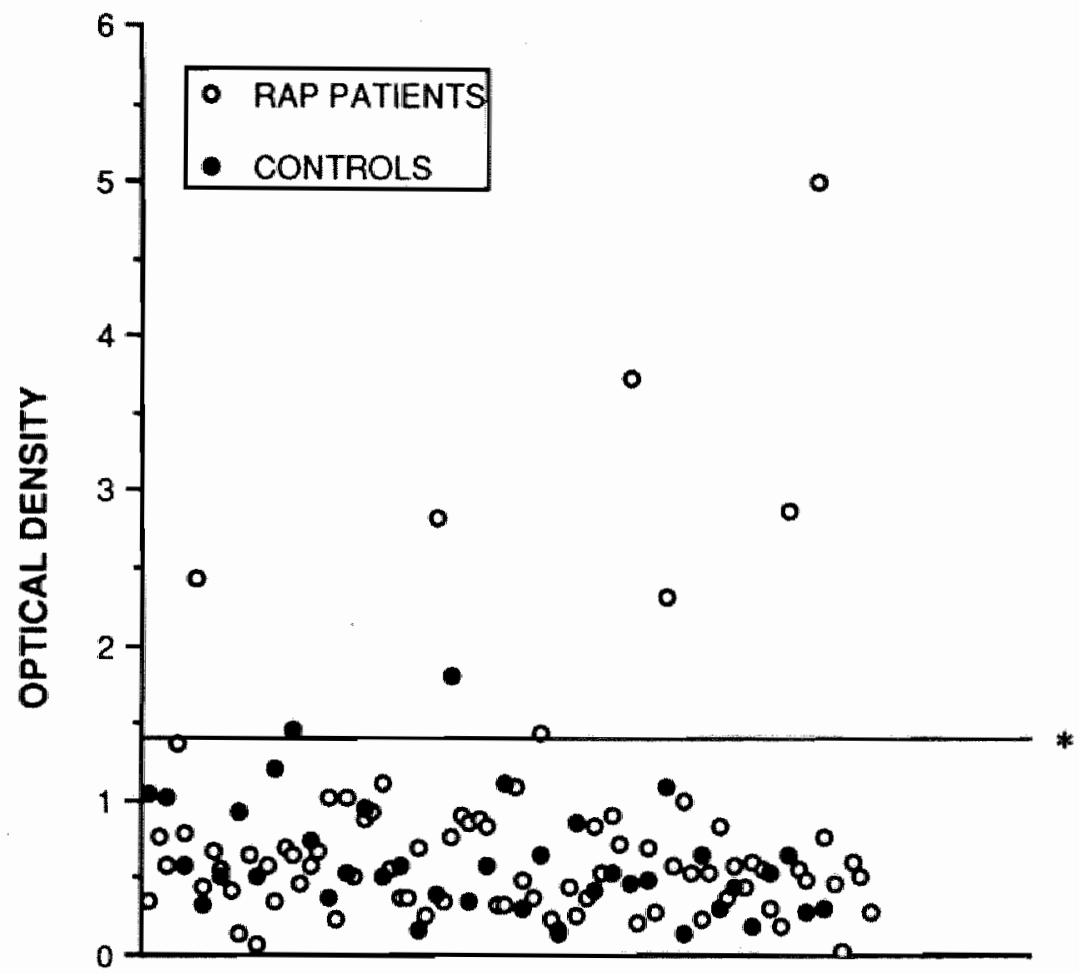

* : cut-off value: $1.40 \mathrm{OD}$

Figure 1:

Scattergram representing the $O D$ values of children with RAP and control children. 


\subsection{Discussion}

As in adults the detection of $H$ pylori in children mainly relies on microscopic investigation of endoscopically obtained mucosal biopsy specimens. Because of its invasive character endoscopy is not always an appropriate and feasible way of diagnosing children suspected of gastrointestinal disease. Therefore, the availability of a sensitive and specific serological diagnostic test would be much appreciatied by pedia tricians, parents and children. Several studies have reported on the use of enzyme-linked immunosorbent assays (ELISA) in detecting the presence of antibodies to $\mathrm{H}$ pylon (16, 17,18 ). The sensitivity and specificity of this test appears to be sufficient in clinical practice (19). In this context we chose to detect $H$ pylori antibodies by means of an ELISA rather than in biopsy specimens.

In adults. $H$ pyllori has been reported to be associated with antral gastritis (22), non-ulcer dyspepsia (23) and peptic ulcer disease (24). Subsequently, there have been reports on the presence of $\mathrm{H}$ pylori in children with these gastrointestinal disorders. Drumm et al (10) and Killbridge et al (11) described the presence of $\mathrm{H}$ pylori in children with antral gastritis and duodenal ulcer disease. These studies were all retrospective investigations of histologic biopsy specimens from children with upper gastrointestinal symptoms such as epigastric pain or vomiting. The prevalence of $H$ pylori in different gastrointestinal disorders in children is reported to range from 6 to $30 \%(25,26)$, depending upon the study design: retrospective or prospective, and the study population.

In this context, it is surprising that no studies explicilly adressing the possible association between RAP and H pylori have been reported so far. In a retrospective study, Mahony et at (27) investigated 38 gastric biopsies from children endoscoped for upper gastrointestinal symptoms. In 9 (38\%) of the patients they found histologic evidence of $\mathbb{H}$ pylori. Most notably, 7 of these $H$ pylori positive patients presented with epigastric pain while 13 other patients presenting with periumbilical pain were all negative for $\mathrm{H}$ pylori. The typical location of the pain in RAP is periumbilical (1). Nevertheless, the authors conclude that $H$ pylori represents another identifiable cause for RAP in children.

Oderda et al (28) reponted on a series of 51 consecutive children presenting RAP. They were investigated through upper gastrointestinal endoscopy. As many as $32(61 \%)$ of the patients showed histological evidence of gastritis and $H$ pylori was present in the antral biopsy specinnens. However, the clinical description of the patients was very limited, making it uncertain that these were "classic" RAP patients. The studies mentioned above presented results that seem to be overestimated. They predominantly concemed selected patients, referred to specialized gastroenterology units. The results of our study show that signs of past or present $H$ pylori infection are present in some children with RAP. Therefore, $H$ pylori infection could be regarded as a possible somatic cause for the RAP syndrome. However, if $\mathrm{H}$ pylori infection often accompanied RAP one would expect a much higher prevalence of $\mathrm{H}$ pylori antibodies in RAP patients as compared to controls. Since this was not the case we do not consider $\mathrm{H}$ pylori to be frequently involved in RAP. On the basis of our study design, we believe we have studied a relatively representative group of RAP patients. "Therefore, the results of our study probably gives the best estimate of the prevalence of $H$ pylori serum antibodies among children with RAP, so far. However, making the diagnosis on the basis of serology only, as we have done, might negatively affect the observed prevalence of $H$ pylori. As the ELISA we used has been reported to be very sensitive and specific for the detection of $\mathrm{H}$ pylori infection (15) we believe our results give a correct estimate of the prevalence of $\mathrm{H}$ pylori infection in our 
study groups.

Finally, it is still open to discussion whether $H$ pylon is causally related to RAP in children. From the 7 seropositive patients in our RAP group, 6 demonstrate a higher antibody titer compared with the 2 seropositive controls. This could imply that $\mathrm{H}$ pylori does play a role in the clinical syndrome of these patients. As in adults suffering from non-ulcer dyspepsia, $H$ pylori can be responsible for the abdominal complaints in sone children sulfering from RAP. However, in 3 out of 7 seropositive patients the abdoninal pain resolved spontaneously. The 3 patients that were treated with bismuth and tinnidazole are free from abdominal pain. The follow-up period, however, is too short to consider therapy either as successful or useful. Furthermore, the number of patients is too small to allow for conclusions. A double-blind therapeutical study could help to clear this problem. Such a study will have to be perfomed among a well-defined group of RAP patients in order to avoid the bias of patient selection. 


\subsection{References}

(1): Apley $J$ and Waish $\mathbb{N}$. Recurrent Abdominal Pains: A field survey of 1000 shoolchildren. Arch Dis Child 1958: 33: 165-170

(2): Apley J.The Chidd with Abdominal Pains. London, Blackwell Scientific Publicafions. 1959, 2nd edition 1975

(3): Barr RG, Levine MD and Watkins JB. Recurrent abdominal pain due to lactose intolerance. New Engl J Med 1979; 300: 1449-1452.

(4): Lebenthal E, Rossi "RM, Nord KS and Branski. D. Recurrent abdominal pain and lactose absorption in children. Pediatrics 1981; 67: 828-832.

(5): Pineiro Carrero VM, Andres JM, Davis RH, Mathias JR. Abnornal gastroduodenal motility in children and adolescents with recunent functional abdominal pain. J Pediatr 1988; $113: 820-825$.

(6): Apley $\mathbf{J}$, Hale B. Children with recurrent abdominal pain: How do they grow up ? Br Med J 1973; 3; 7-9.

(7): Liebman WM. Recurrent abdominal pain in children: A retrospective study of 119 patients. Clin Pediatr 1978; 17: 149-153.

(8): Green M. Diagnosis and treatment: Psychogenic, recurrent, abdominal pain. Pediatrics 1967; 40: 84-89.

(9): McGrath PJ, Goodman JT, Firestone P, Shipman $\mathbb{R}$ and Peters S. Recurrent abdominal pain: a psychogenic disorder ? Arch Dis Child 1983; 58: 888-890.

(10) Drumm B, O'Brien A, Cutz E and Sherman P. Campylobacter pyloridis-associated primary gastritis in children. Pediatrics 1987; 80: $192-195$.

(11) Killbridge PM, Dahms BB, Czinn SJ. Campylobacter pylori-associated gastritis and peptic ulcer disease in children. Am J Dis Child 1988; 142: $1149-1152$.

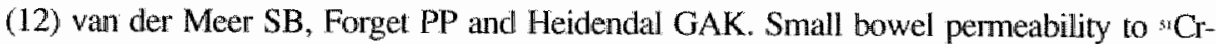
EDTA in children with recurrent abdominal pain. Acta Paed Scand 1990; 79: 422 - 426.

(13) van der Meer SB, Forget PP, Arends JW, Kuijten RH and van Engellshoven JMA. Diagnostic value of Ultrasound in children with Recurnent Abdominal Pain. Ped Radiol $1990 ; 20: 501-503$

(14) van der Meer SB, Forget PP and Arends JW. Abnomal small bowel permeability and duodenitis in Recurrent Abdominal Pain. Arch Dis Child 1990; 65: 1311 - 1314.

(15) Loffeld RJLF, Stobberingh E, Flendrig JA, van Spreenwel JP and Arends JW. Diagnostic value of an immunoassay to detect anti campylobacter pylori antibodies in non-ulcer dyspepsia. Lancet 1989; i: $1183-1185$.

(16) Mitchell HM, Lee A, Berkowicz J and Borody $T$. The use of serology to diagnose active Campylobacrer pylori infection. Med J Aust 1988; 149: 604 - 609 .

(17) Wyat II and Rathbone B.I. The role of serology in the diagnosis of Campylobacter pylori infections. Scand J Gastroenterol 1989; 24 (suppl 160): 27 - 34 .

(18) Evans DJ, Evans DG, Graham DY and Klein P. A sensitive and specific serologic test for detection of Campylobacter pylori infection. Gastroenterology 1989; 96: 1004 $-1008$.

(19) Newell DG and Rathbone BJ. Review article: The serodiagnosis of Campylobacter pylori infection. Serodiagnosis Immunother $1989 ; 3 ; 1-6$.

(20) Jones DM, Eldridge J, Fox AJ, Sethi $P$ and Whorwell PJ. Antibody to the gastric campylobacter-like organism (Campylobacter pyloridis) - clinical correlation and distribution in the nomal population. J Med Microbiol 1986; 22: 57 - 62 . 
(21) Mahony MJ and Littewood JM. Campylobacter pylori in paediatric populations. In: Campylobacter pylon. Ratlibone BJ and Heatly RV (eds) London, Blackwell 1989 ; pp. $167-175$.

(22) Rauws EA, Langenberg W, Houthoff H, et al. Campylobacter pylondis-associated chronic active antral gastritis. Gastroenterology 1988; 94:33-40.

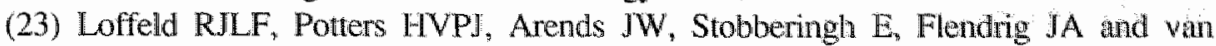
Spreeuwel JP. Campylobacter associated gastritis in patients with non-ulcer dyspepsia. J Clin Pathol 1988; 41: 85 - 88.

(24) Buck GE, Gourley WK, Lee WK, of al. Relation of Campylobacter pyloridis to gastritis and peptic ulcer. J Infect Dis 1986; 153: $664-669$.

(25) Drumm B, Sheman P, Cutz E and Karmali M. Association of Campylobacter pylori on the gastric mucosa with antral gastritis in children. $\mathrm{N}$ Engl J Med 1987; 316: 1557 1561 .

(26) Thomas JE, Eastham EJ, Elliot TSJ and Nelson R. Campylobacter pylori in children - a common cause of symptoms. Gut 1988; 29: A707.

(27) Mahony MJ, WyatJI and Littlewood JM. Campylobacter pylori gastritis. Arch Dis Child 1988; 63:654 - 655

(28) Oderda G, Vaira D, Holton J, Dowsett JF and Ansaldi N. Serum pepsinogen and IgG antibody to Campylobacter pylori in non-specific abdominal pain in childhood. Gut 1989; 30: 912 - 916. 


\section{Diagnostic Value of Ultrasound in Recurrent Abdominal Pain}

S.B. van der Meer, P.P. Forget, J.W. Arends, R.H. Kuijten, J.M.A. van Engelshoven

\section{Summary}

In order to investigate the diagnostic value of ultrasound in children with recurrent abdominal pain and to estimate the clinical relevance of rare organic causes of abdominal pain in these patients, we prospectively examined 93 children aged between 5.5 and 12 years by means of abdominal ultrasound. In 3 patients $(3.2 \%)$ an anatomic abnormality was detected, which could not account for the abdominal pain.

We conclude that many organic abnormalities, that could be diagnosed by ultrasound, are clinically irrelevant as a cause of recurrent abdominal pain in children and therefore ulltrasound does not significantly contribute to the diagnosis. However, ultrasound can still play a role in the work-up of children with recurrent abdominal pain in avoiding unnecessary radiologic $X$-ray procedures.

(Pediatric Radiology 1990; 20: 501 - 503) 


\subsection{Introduction}

Recurrent abdominal pain (RAP) is a frequent and puzzling syndrome in children: Most authors use the criteria laid down by Apley to describe the clinical condition (1). In spite of its frequent occurrence, little progress has been made during recent yeas to clarify the nature of this syndrome $(2,3)$. This may be partly due to the relative vagueness of this clinically defined entity. Findings have been either contradictory $(4,5)$, or showed evidence of possible new causes (chapter 3 and 4) $(6,7)$, dependent on the approach of the condition. It seems likely, that several causes can be responsible for this syndrone. Pediatric textbooks and manuscripts on RAP, often list long compilations of possible organic causes of RAP, most of which are rare $(8,9,10)$. Although the known organic causes vary strongly, they all lead to the same clinical symptoms: recurrent bouts of abdominal pain; mostly with a periumbilical localization, existing over a longer period (three months or more) and interfering with the childs" nomal activities.

In a large study of school-aged children, an organic cause was found in $10 \%$ (1.1). In spite of this low incidence of organic disease, RAP frequently leads to nefertal to specialized centers where most authors describe the use of radiologic procedures to nule out organic causes like Crohns. disease, colitis, hydronetrosis etc (12,13). Because of the low yield of extensive radiologic procedures like plain abdominal films, barium enemas, intravenous urographys in children with RAP, the diagnostic value of radiology is open to discussion. Furthemore, the majority of the radiologic examimations mentioned above, require high closes of ionizing radiation, which renders them less suitable for children. With the development of high resolution real-time scanners, ultrasound (US) has become an important diagnostic imaging modality in the pediatric patient. In some cases, US has tended to replace more conventional investigations in the evaluation of abdominal complaints in children $(14,15)$.

Little is known about the diagnostic value of US in children with RAP. In a retrospective study of a 100 children with RAP, Rubio Quinones ef al, using US as a diagnostic tool, reported organic abnormalities in 13 of their patients (16). They found 2 patients with a duodenal ulcer, 2 with lymphoid hyperplasia, 1 with gallbladder stones, I with intestinal tuberculosis, 1 with a Burkitt lymphoma, 3 with a double pyeloureteral system, 1 with hydronephrosis, 1 with vesicoureteral reflux and 1 with pyelonefritis. In 7 out of these 13 patients the diagnosis was made by US and they conclude that US can be useful in this type of patients. However, it seems questionable that a double pyeloureteral system or lymphoid hyperplasia can account for recument bouts of abdominal pain. To our knowledge, no other report has been published on the diagnostic value of US in children with RAP.

Most of the possible organic causes are tare and little is known about their clinical rellevance in RAP. The abnormalities listed in lable 1, are possible onganic causes of RAP and can be diagnosed by US. Therefore, one of the aims of a prospective study initiated in our institution on RAP patients, was to evaluate the diagnostic value of US in a carefully assembled group of children with this condition. Further, we intended to study the incidence of the abnormalities mentioned in table $\mathbb{l}$ in order to estimate their clinical relevance in children with RAP. 


\section{Gastrointestinal tract}

(intermintent) intussusceprion

dwadenal cysts

mesemerial cysts

omentum cysts

Urogenital tract

hydronefrosis

renal calcult

renal cysts

renal neoplasms

adrenal cysts and numors

owarian cysts

retroperitoneal cysts

bladder stones

\section{Liver spleen, pancreas}

hepatic cysts

hepatic mamots

hepatic abcess

choledochal cyots

hydrops of the

galbladder

gall bladder stones

pancreatic cysts

pancreatic tumors

pancreatic calcifications

pancreatitis

(massive) splenomegaly

\section{Table 1:}

Possible organic causes of recurrent abdominal pain, which can be diagnosed by ultrasound.

\subsection{Patients and Methods}

During a prospective study on RAP, 106 children between the age of 5.5 and 12 years were investigated. They all met the inclusion criteria laid down at the beginning of the study: at least a six months period of recumrent abdominal pain, varying in severity and duration, sometimes accompanied by vegetative symptoms as nausea or paleness.

The majority of the patients were referred to our out-patient clinics by their general practitioners, or schooldoctors. Both groups of colleagues were informed about the study. All parents gave informed consent. Only two refused to take part in the sudy. The study protocol consisted of laboratory examimation of blood, urine and stools, a small bowel permeability test with "Cr-EDTA as a marker, and a lactose toletance test making use of breath hydrogen content measurements. The US examination of upper and lower abdomen was scheduled after the first visit to our outpatient clinics. The examination was performed by a radiologist using a mechanical sector scamer (Technicare: autosector or moc. Pie Dala: 1 20) and a 3.5 or $5 \mathrm{mHz}$ transducer. Special attention was drawn to the intemal organs, like the pancreas, the liver and gallbladder and the urogenital bact.

In the present paper we only present results of the US findings.

\subsection{Results}

In 93 cases US acconding to the above mentioned procedune was performed. In 13 cases either the parents refused the examination or the patient was not cooperative. Table 2 shows our results of $93 \mathrm{US}$ examinations of the abdomen in children with RAP. In 3 cases 
(3.2\%) organic abnormalities were observed. In one patient a duplex kidney was seen. A second patient appeared to have unilateral kidney agenesia, whereas a third patient demonstrated an enlarged spleen. Three patients revealed a bladder residue after voiding. In 87 cases (93.5\%) no organic abnomalities were detected on uitrasound examination.

\begin{tabular}{lc}
\hline duplex kidney & 1 \\
unilateral kidney agenesia & 1 \\
enlarged spleen (9 cm) & 1 \\
bladder residue (after voiding) & 3 \\
normal findings & 87 \\
\hline Table 2: \\
Results of ultrasound examination in 96 children with recurrent abdomi- \\
nal pain
\end{tabular}

\subsection{Discussion}

The relevance of our abnormal anatomic findings for the RAP syndrome is open to doubt. In the patient where an enlarged spleen was found on US, physical examination did not reveal a palpable spleen. The child with a duplex kidney did not suffer from urinary tract infections, whereas the child with a unilateral kidney agenesia appeared to have a normal renal function. A bladder residue after voiding is a frequent non-pathologic finding in children. Given these considerations, our results indicate that in our group of RAP patients no abnormalities could be detected which could account for their abdominal complaints. Therefore, two main conclusions can be drawn from our study. In the first place, organic abnormalities as mentioned in table 1 , are only very exceptional, clinically rather irrelevant, causes of recurrent abdominal pain in children.

Secondly, US does not significantly contribute to the diagnosis in RAP. Ultrasound however, may rule out centain organic causes usually investigated by means of radiologic $X$-ray procedures. Against this background US still has a role in the work-up of RAP patients, particularly in those patients where either history or physical examination raise suspicion to one of the abnormalities referred to in pediatric textbooks and manuscripls. However, given the limited place of US in the work-up of RAP, to detect apparently rare underlying conditions, the role of radiologic $X$-ray procedures needs careful reconsideration. On the basis of this observation it is our view that a greal deal of possible organic disease can be ruled out by US, making the use of extensive $X$-ray procedures less appropriate. Furthermore, recent developments in US techniques may extend the possible diagnostic applications with regard to RAP in the near luture, particularly in case of suspected inflammatory bowel disease (15), which might play an important wole in the etiology of RAP, considering our findings in recent reports (chapter 3 and 4) (6, 7). 


\subsection{References}

(1). Apley $\mathfrak{J}$ and Naish N. Recurrent Abdominal Pains: a field survey of 1000 school children. Arch Dis Child 1958; 33: $165-70$.

(2): Magni G, Pierri M and Donzelli F. Recurrent abdominal pain in children: a long term follow-up. Eur J. Pediar 1987; 146: $72-74$.

(3): McGrath PJ, Goodman IT, Firestone P, Shipman R and Peters S. Recurrent Abdominal Pain: a psychogenic disorder ? Arch Dis Child 1983; 58: 888 - 890.

(4): Barr G, Levine DL and Watkins JB. (1979) Recurrent Abdominal Pain of Childhood due to lactose intolerance. New Engl J Med 26: $1449-1452$.

(5): Lebenthal E, Rossi TM, Nord KS and Branski D. Recurrent abdominal pain and actose malabsorption in children. Pediatrics 1981; 67: 828 - 32.

(6): van der Meer SB, Forget PP and Heidendal GAK. Small bowel permeability to "Cr-EDTA in children with recurrent abdominal pain. Acta Paed Scand 1990; 79: $422=426$.

(7): van der Meer SB, Forget PP and Arends JW. Abnormal small bowel permeability and duodenitis in recurrent abdominal pain. Arch Dis Child 1990; 65: $1311-1314$. (8): Dodge JA. Recurrent abdominal pxin in children. Brit Med I 1976; i: 385 - 387. (9): Walker-Smith JA, Hamilton JR and Walker WA. in: Practical paediatric gastroenterology. Butterworths, London, 1983; pp: $30-42$.

(10): Levine MD and Rappaport LA. Recurrent abdominal pain in schoolchildren: the loneliness of the long-distance physician. Pediatr Clin Nonth Am 1984; 31: 969 - 991. (11): Apley J. The Child with Abdominal Pains, second edition. Blackwell, Oxford, 1975.

(12): Hodges $\mathrm{K}$, Kline JJ, Barbero $\mathrm{G}$ and Flanery R. Depessive symptoms in children with recurrent abdominal pain and in their families. J Pediatr 1985; 107: 622 - 626.

(13): Feuerstein M, Barr RG, Francoeur TE, Houle $M$ and Rafman S. Potential biobehavioral mechanisms of recurrent abdominal pain in children. Pain 1982; 13: 287 $-298$.

(14): Miller JJ Kemberling CR. Ultrasound scanning of the gastrointestinal tract in children. Subject review. Radiology 1984; 152: 671 - 678 .

(15): Swischuk LE, Hayden CK, Boulden T. Intussusception: Indications for ultrasonography and an explanation of the donut and pseudokidney sign. Pediatr Radiol 1985; 15: $388-391$.

(16): Rubio-Qünones F, Rodenas-Luque G, Garcia-Abeja JC, Garcia-Hernandez J Abdominal echography in recurrent abdominal pain: study in 100 cases. An Esp Pediatr $1988 ; 29: 217-219$.

(17): Dinkel E, Ditrich M, Peters $H$ and Baumann W. Real-time ultrasound in Crohns' discase: characteristic features and clinical implications. Pediatr Radiol 1986; 16:8 -12 . 


\title{
Diagnostic Contribution of "Routine" Laboratory Investigations in Recurrent Abdominal Pain
}

\author{
S.B. van der Meer, P.P. Forget, R.H. Kuijten, J.W. Arends
}

\section{Summary}

In order to evaluate the significance of "routine" laboratory investigations in the diagnostic approach of children with Recurrent Abdominal Pain and try to establish an effective and generally applicable diagnostic approach for these patients we prospectively investigated 106 children aged between 5.5 and 12 years and presenting recurrent abdominal pain for a minimum period of 6 months. All patients were submitted to a standard protocol consisting of laboratory investigations of blood, wrine and stools. In addition more sophisticated investigations were performed such as small bowel permeability tests, ultrasound examination of the abdomen, 24-h $\mathrm{pH}$ monitoring and upper gastrointestinal endoscopy with duodenal and antral biopsies. Our results show that "routine" laboratory investigations of blood, urine and stools do nol contribute to the diagnosis in these patients. In contrast, the more sophisticated tests demonstrate somatic abnormalities in $42 \%$ of the total study group. We conclude that the presently used diagnostic approach of patients with Recurrent Abdominal Pain appears to be inadequate. However, with the aid of more sopluisticated investigations abnomalities may be found in a much higher percentage of patients.

(submitied for publication) 


\subsection{Introduction}

Recument abdominal pain (RAP) is one of the most frequent gastrointestinal problem in school age children. At least 10\% of the primary school population suffers from recurnent bouts of thdominal pain (1). The general practitioner probably only sees a small part of all children with RAP, and of these only some are referred to a specialist such as a pediatric gastroenterologist, a surgeon or a psychologist. In the majority of cases no underlying somatic abnormality can be found (2). Moreover, the abnormalities reported to be associated with RAP are quite varied. Psychological disturbances $(3,4)$ as well as gastroenterological abnomalities $(5,6,7)$ have been reported to be associated with RAP in children. As a result, specific treament is rarely given, and patients are often left with their complaints. Due to the many unanswered questions conceming RAP, the diagnostic approach of these patients varies greatly, ranging from cases in which no investigations are carried out to other cases which are extensively investigated. Whether extensive investigation leads to better diagnostic efficiency and whether the proper investigations are used in making a diagnosis is open to discussion. In previous studies we already reported the diagnostic yield of various more sophisticated investigations we performed in a group of 106 schoolchildren with RAP. Small bowel permeability tests making use of schromium labelled ethylenediaminetetraacetate (sCr-EDTA) demonstrated an abnomal permeability in $54 \%$ of our patients (chapter 3) (8). Ultrasound examinations of the abdomen did not contribute to the diagnosis in RAP (chapter 7) (9). However, the use of ultrasound examinations often decreases the need for radiologic $\mathrm{X}$-ray procedures. With upper gastrointestinal endoscopy and duodenal biopsy we observed abnormalities in $33 \%$ of the investigated patients (chapter 4) (10). Finally, 24-hour intraesophageal pHmonitoring appeared to be abnomal in $56 \%$ of the 25 investigated patients (chapter 5 ) (11).

"The aim of the present study was firstly, to compare the usefulness of widely used rouline laboratory investigations to that of more sophisticated investigations in children with RAP and seconclly, to give a tentative standardized approach to the problem of RAP in children taking into account of our previous findings.

\subsection{Patients and Methods}

During a prospective study, 106 children with RAP were investigated by means of a standard protocol. Patients were considered to suffer from RAP when the following criteria were met:

1). age range 5.5 to 12 years,

2). recurrent abdominal pain of unknown origin for a minimum period of 6 months,

3). attacks of pain varying in severity, duration and frequency,

4). sometimes accompanied by vegetative symptoms such as paleness, nausea and vomiting. All children referred to our outpatient clinics with RAP and those admitted to the pediatric ward, who met the criteria, were included in the study. All children were referred to us by their general practitioners or by school doctors. All parents gave infomed consent. The protocol consisted of a thorough physical examination, additional laboratory investigations of blood, facces and urine as presented in mone detail in table 1. Lactose tolerance was tested with an oral lactose load of $2 \mathrm{~g} / \mathrm{kg}$ body weight, with a maximum of $50 \mathrm{~g}$. Breath samples were analyzed at 30 minute intervals for up to two 
hours, using a Lactoscreen (HoekLoos). Hydrogen content values of breath samples were considered abnomal when exceeding 20 ppm.

An ultrasound examination of the albdomen according to a standard procedure as well as a small bowel permeability test was performed making use of :Cr-EDTA as a marker. Finally, all parients were seen by a psychologist who performed a variety of psychological tests. Part of the patients also underwent endoscopy during which a duodenal and/ or an antral biopsy was taken. In some cases a 24-hour intraesophageal pll monitoring was performed as well. Only results concerining haematologic, clinical chemistry, urine and stool laboratory investigations are reported in detail in the present paper. Results of the other more sophisticated investigations such as lactose breath hydrogen tests, small bowel permeability tests, ultrasound examinations of the abdomen, upper gastrointestinal endoscopies and $\mathrm{pH}$ monitoring have been reported in chapter $3,4,5$ and 7 , and are only summarized under results $(8-12)$.

\begin{tabular}{lc}
\hline Haematology & Clinical Chemistry \\
Haemoglobin & $G P T$ \\
Haematocrit & $S G O T$ (ASAT) \\
ESR & SGPT (ALAT) \\
leucocyte count & Urea \\
leucocyte differentiation & Crearinine \\
Urine & Total protein and Electrophoresis \\
protem & IgE and Phadiatoop $\mathbb{B})$ \\
glucose & Stools \\
keton bodies & occult blood $(3 x)$ \\
sedimentation & ova and parasites $(3 x)$ \\
\hline
\end{tabular}

\section{Table 1:}

Laboratory investigations routinely performed in our patients.

\subsection{Results}

\section{Haematology}

Haematologic laboratory investigations were performed in 98 patients. Haemoglobin, haematocrit, ESR, leucocyte count and differentation were nomal in all but 9 patients. In 3 cases a low haemoglobin was observed, in 6 cases the ESR was raised above 15 mm in the first hour. In none of these patients a link could be found between the raised ESR and the abdominal pain. Differentiation of leucocytes showed a high number (up to $15 \%$ ) of eosinophilic leucocytes in 4 cases. Three of these patients also had an elevated level of $\operatorname{IgE}$ (up to $930 \mathrm{kU} / \mathrm{L}$ ), whereas in none of them oval or parasites were found in the stools. 


\section{Clinical Chemistry}

In 95 cases the laborattory investigations as mentioned in table 1 were canied out. Liver-and kidney function tests, total protein level and protein electrophoresis were nomal in all patients.

The mean level of IgE in 96 patients was $325 \mathrm{kU} / \mathrm{SEM} 65 \mathrm{kU} /$ ), values ranging from 3 to $3310 \mathrm{kU} /$. The search for specific allergens by means of Phadiatoop $\mathrm{B}$ demonstrated positive findings in $16(16.7 \%$ ) patients. In 11 patients inhalation allergens as house-dust and animal dander were positive, whereas 5 patients demonstrated positive titers towards food allergens such as fish, milk, wheat, rye, barley, soy, peanuts or hazelnuts. In 3 of these patients an elimination diet resulted in disappearance of the abdominal pain. Challenging them with these food-allergens resulted in recurrence of abdominal pain within 24 hours.

\section{Urine}

Urine was investigated in 97 patients. In 2 patients a slight proteinuria $(0.5 \mathrm{~g} / \mathrm{l})$ was observed. Additional investigations did not reveal any pathological explanation for this finding. In both children the proteinuria disappeared spontaneously. In 2 children leucocytes were present in the urinary sediment. Subsequent urine cultures were sterile. A second study of the urinary sediment gave normal results.

\section{Stools}

In 83 patients stools were collected 3 times in order to look for occult blood loss. In 12 patients a trace of blood was found with the Hematest ${ }^{\text {mw }}$. Strong positive findings were not observed. Even the patients with proven gastroesophageal reflux did not show a positive test reaction.

Investigation of the stools for ova and parasites was performed 3 times in each of 93 patients and revealed the presence of Enterobius Vermicularis (oxycuriasis) in 2 patients, whereas in 5 patients Giardia Lamblia was discovered. Appropriate treatment (mebendazole or metronidazole respectively) did not have any effect on the abdominal pain in spite of eradication of the parasites.

\begin{tabular}{lccc}
\hline $\begin{array}{l}\text { Laboritory } \\
\text { Investigation }\end{array}$ & $\begin{array}{l}\text { Number of } \\
\text { Patients } \\
\text { Investigated }\end{array}$ & $\begin{array}{l}\text { Abnomal } \\
\text { Result } \\
(\%)\end{array}$ & $\begin{array}{l}\text { Contribution to } \\
\text { Diagnosis } \\
(\%)\end{array}$ \\
\hline Haematology & 98 & $9(9.2 \%)$ & 0 \\
Clinical Chemistry & 95 & $0(0 \%)$ & 0 \\
lgE/Phadiatoop@ & 96 & $16(16.7 \%)$ & 3 \\
Urine & 97 & $4(4.1 \%)$ & 0 \\
Stools & & $12(14.5 \%)$ & 0 \\
Occult blood & 83 & $7(7.5 \%)$ & 0 \\
Ova and Parasites & 93 & &
\end{tabular}

\section{Table 2:}

Results of routine laboratory investigations in our patient group. 


$\begin{array}{llll}\text { Laboratory } & \text { Number of } & \text { Abnormal } & \text { DHAMOSAS } \\ \text { Investigation } & \text { Patienis } & \text { Result } & \\ & \text { Inwestigated } & (1 \%)\end{array}$

24-h pH monitoring

Lactose Breath

Hydrogen Test

Endoscopy/biopsy

H pylori Histology

H pylori Serology

IgE/Phadiatoop $\mathbb{B}$

25

92

39

11

79

96
$14(56 \%)$

$15(16.3 \%)$

$13(33 \%)$

$8(73 \%)$

$7(8.9 \%)$

$3(3.1 \%)$
GER

Lactose Intolerance Duodenitis and/or Gastritis H pylori infection* H pylori infection Food Allergy

GER: Gastroesophageal Reflux; H pylori: Helicobacter pylori.

\section{Table 3:}

Total of Somatic Abnormalities in the Study Group, detected by different "non-routine" laboratory investigations.

Observed Abnormality

\begin{tabular}{|c|c|c|c|c|c|c|}
\hline $\begin{array}{l}\text { Pat } \\
\text { Nr. }\end{array}$ & $\begin{array}{l}\text { Food } \\
\text { Allergy }\end{array}$ & Duodenitis & Lactose & $\begin{array}{l}G E R^{\text {"I }} \\
\text { Intolerance }\end{array}$ & $\begin{array}{l}\text { H pylorit } \\
\text { Ser/hist }\end{array}$ & $\begin{array}{l}\text { Number of } \\
\text { Abnomalities }\end{array}$ \\
\hline 1 & + & + & - & - & + & 3 \\
\hline 2 & - & + & - & - & + & 2 \\
\hline 3 & - & + & - & - & + & 2 \\
\hline 4 & - & + & - & - & + & 2 \\
\hline 5 & - & + & - & + & - & 2 \\
\hline 6 & - & - & - & + & $+1+$ & 3 \\
\hline 7 & - & - & + & + & 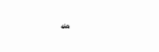 & 2 \\
\hline 8 & - & + & - & + & - & 2 \\
\hline 9 & - & + & - & - & $+1+$ & 3 \\
\hline 10 & - & + & - & - & + & 2 \\
\hline 11 & - & + & - & + & - & 2 \\
\hline 12 & - & - & + & + & + & 3 \\
\hline
\end{tabular}

*: GER: gastroesophageal reflux

\#: H pylori ser/hist: Hellicobacter pylori serology and/or histology

\section{Table 4:}

The patients with more than one abnormality resulting from different sophisticated laboratory investigations 
Results of these routine inwestigations are summarized in table 2. Table 3 shows a conipilation of our previous reported data conceming some more sophisticated irvestigations which we performed on our patient group such as lactose breath

hydrogen tests, small bowel permeability tests (chapter 3) (8), upper gastrointestinal endoscopy in combination with duodenal and antral biopsy and histologic evidence of duodenitis and Helicobacter pyloni (H pylori) gastritis (chapter 4) (10), 24 h intraesophageal $\mathrm{pH}$ monitoring (chapter 5) (11) and serologic evidence of $\mathrm{H}$ pylon (chapter 6) (12). From the total study group of 106 patients, we observed 60 abnormalities as described above, in 44 different patients. In 8 patients 2 different abnomalities were observed, whereas 4 patients demonstrated 3 abnormalities. With this diagnostic spproach we were able to detect somatic abnomalities in $42 \%$ of our patients (table 4).

\subsection{Discussion}

General practitioners as well. as pediatricians are often confronted with children suffering from obscure complaints such as headaches, limb pains or abdominal pain. In most cases, when history and physical examination do not provide any clue, additional laboratory investigations are carried out in order to exclude possible somatic disorders which could account for the complaints. There is no common approach towards the above mentioned disorders and the quantity of additional laboratory investigations strongly varies depending upon the complaints presented and the attitude of the doctors towards these disorders. Particularly in children with RAP there is a tendency to expect little from additional investigations since RAP is regarded as a predominantly psychosomatic disorder (13). Nevertheless, although somatic disorders are reported to be present in no more than $10 \%$ of RAP patients (2) many investigators cany out a variety of laboratory investigations in order to exclude a possible somatic disorder in these patients $(14,15)$. When haematology, clinical chemistry and urinalysis show no abnormalities child and parents are frequently reassured and told that "nothing is wrong". Our results, however, show that these widely used "routine laboratory investigations" appear to show abnomal findings in only a small number of cases. Moreover, the abnomalities found do not often seem to be responsible for the abdominal pain. This makes this diagnostic approach at least questionable.

Our results show that the "non-routine" approach results in the frequent detection of abnomalities in these pattients. The systematic use of these sophisticated investigations in RAP patients only seems appropriate when the causal role of the detected abnomalities will be strongly proven. "The latter is at present still uncertain.

Lactose intolerance has been reported to be frequently present in children with RAP and dietary treatment can result in reduction and disappearance of the complaints $(16,17)$. Controlled studies, however, could not confirm these findings $(18,19)$. Our patients with lactose intolerance were treated with a lactose-poor diet. In 11 (73\%) patients the abdominal pain disappeared. When lactose was again added to the diet the abdominal pain reappeared in all of them. The effect of the diet could not be evaluated in 2 patients who were lost to follow-up. The other 2 patients appeared to suffer from gastroesophageal reflux as well. When appropriate treatment (sleeping in anti-Trendelenburg and antacids) was added to the lactose-poor diet both patients became free of abdominal pain. These results suggest an association between abdominal pain and lactose intolerance. The significance of lactose intolerance as a cause for RAP seems still open to discussion. 
In a certain number of RAP patients it does play a role, however, the high percentages reported before seem to be overestimated.

Gastroesophageal reflux (GER) has not been reported to be associated with RAP in children. In adults, however, an association has been reported between the irritable bowel syndrome and GER (20). The symptomatology and pathophysiology of RAP in children and the adult irritable bowel syndrome seem closely related (21). Moreover, treatment of the pathological GER with postural treatment and antacids resulted in improvement or resolution of the abdominal pain in $71 \%$ of our patients. These observations make it likely that pathological GER might play a role in the pathogenesis of the RAP syndrome (chapter 5) (11).

The role of food allergy in children with RAP has not been investigated in detail. Some authors mention abdominal pain as a possible gastrointestinal manifestation of food allergy, but provide no data $(22,23)$. In our patient group only 3 patients were found to improve with dietary elimination of the possible causative allergens detected by means of Phadiatoop $\mathbb{B}$. Our RAP patients appear to have a high mean level of serum $\operatorname{IgE}$. Whether this could point out to (food) allergy playing a role in RAP noeds further investigation. In a previous report we observed an abnomal small bowel permeability

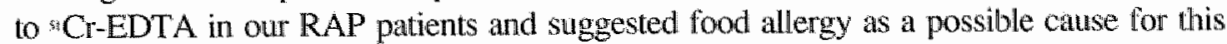
abnomality (chapter 3) (8). There appeared to be no relationship, however, between the level of serum IgE and urinary "Cr-EDTA excretion in our patients. Up to now, the observation of an abnormal small bowel permeability to ${ }^{51} \mathrm{Cr}$-EDTA in our patients remains unexplained. The relationship we reported between duodenitis and abnormal small bowel permeability, however, gives further evidence for an enteral origin in these patients' complaints (chapter 4) (10). Further investigations with more sensitive and specific laboratory investigations might elucidate the possible role of immunologic mechanisms in the pathogenesis of RAP in children.

Finally, the role of Helicobacter pylori ( $H$ pylori) in RAP appears to be less prominent than was to be expected from previous reports $(24,25)$. Our own results show no difference in prevalence of, $\mathrm{H}$ pylori serum antibodies between the study group and a group of matched control children. The high percentage of positive $\mathrm{H}$ pylori histology in our patients is biased by the fact that antral biopsies were only obtained in the presence of endoscopic gastritis. The finding of a positive titer to $\mathrm{H}$ pylori does not necessarily imply that $\mathrm{H}$ pylori is the causative organism. Treatment of $\mathrm{H}$ pylori infection in children with RAP should probably depend upon additional clinical, endoscopic and histological findings.

An important aspect in drawing conclusions from our results in the present sludy is the way in which we compiled our study group. Whether our study population is representative of RAP patients in genert, remains uncertain. However, on the basis of our study design we believe we have studied a reasomably unselected number of RAP patients. The collaboration with the Department of Child Health led to referral of RAP patients that would otherwise not have been seen by a specialist. Furthermore, the results of our study migit well have been influenced by the fact that we chose a period of 6 months as the minimum duration of the abdominal pain. On the basis of our own clinical experience, which had shown that many children with abdominall pain cease to have complaints within 3 to 6 months, we chose 6 months as the 


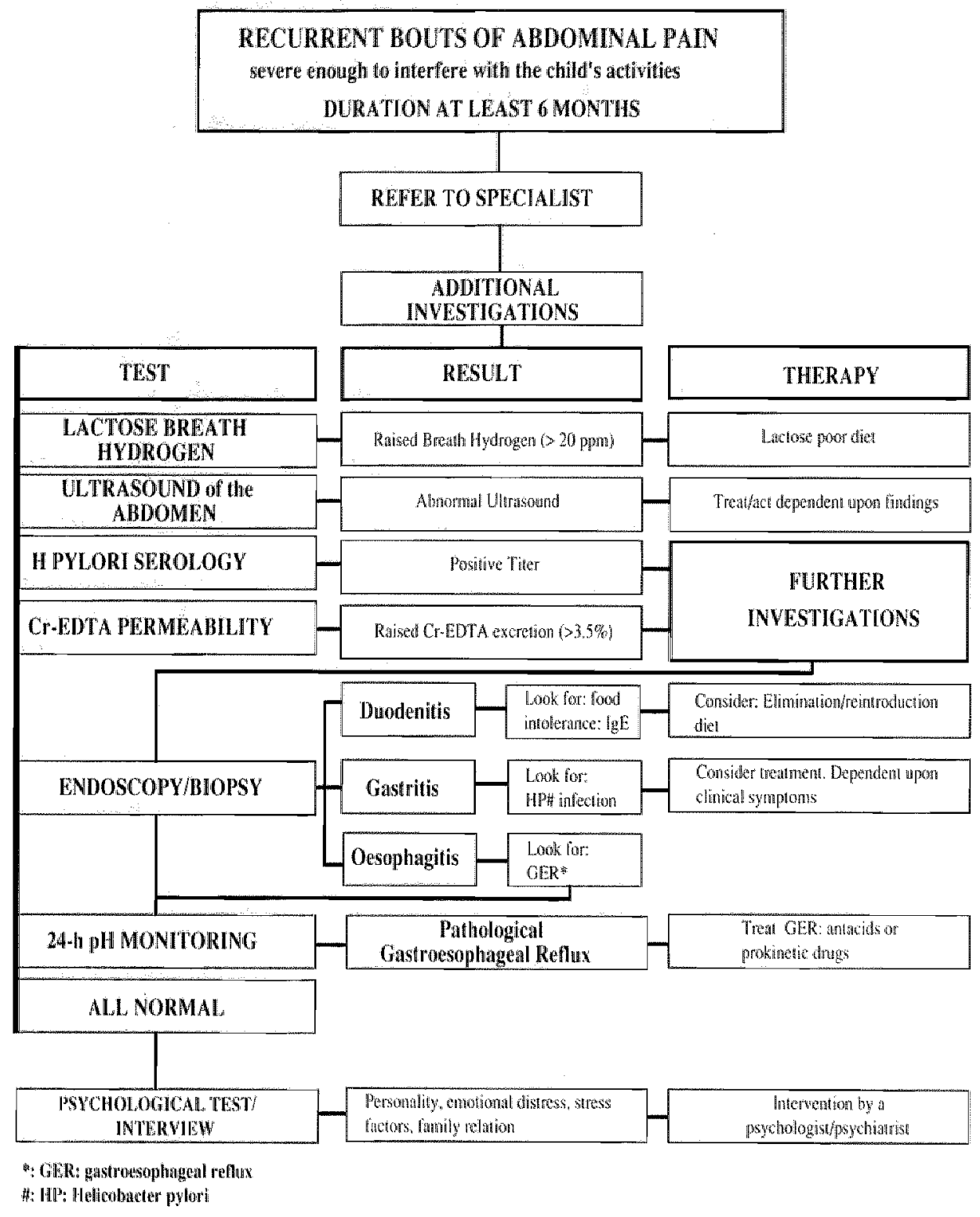

\section{Figure 1:}

Flow diagram representing a possible diagnostic approach towards children with Recurrent Abdominal Pain. 
minimum duration of the complaints instead of the widely used period of 3 months as proposed by Apley in 1958 (1). By choosing a period of 6 months we expected to select the real chronic pain patient instead of patients with transitory abdominal pain. Given the above reservations concerning the pathophysiological significance of our abnormal findings, we would suggest a different diagnostic approach towards children with RAP. This diagnostic approach might lead to the detection of somatic abnomatities more frequently. Moreover, this could stimulate future research conceming this frequent and puzzling syndrome.

On the basis of our results we would advise to investigate RAP patients with a lactose breath hydrogen test, an ultrasound of the abdomen and a small bowel pemeability test. Serologic investigation by means of an ELISA for the presence of $\mathrm{H}$ pylori antibodies and food allergens by means of $\operatorname{IgE}$ and Phadiatoop $B$, could be added to this initial approach. If no abnomalities are found further investigations could be carried out such as 24-h intraoesophageal pH monitoring, upper gastraintestinal endoscopy with mucosal biopsies from duodenum and antrum, particularly when the "Cr-EDTA excretion is raised. If these investigations show no abnomalities then psychological examination of the child and the parents-child relationship should be performed. Figure 1 shows our proposed diagnostic approach to children with RAP in a flow-diagram. This approach does not nule out the general practitioner. On the contrary, the general practitioner plays a crucial role. It is very important that the "classic" and chronic RAP patients are recognized and that parents and patient are taken seriously. The kind of investigations that need to be carried out makes referral of the patients necessary. However, if a patient with abdominal pain is referred too early there is only a small chance that a somatic abnomality will be found considering the findings of other investigators such as Apley et al (2) or Liebman et al (26). On the other hand, neferring a patient presenting RAP for more than a year might mean that the complaints have persisted unnecessarily long. The diagnostic approach towards RAP patients in the outpatient or clinical setting could be limited to the additional investigations as presented in the diagram. In this way, finding a somatic abnormality in a high percentage of patients appears to be possible. 


\subsection{References}

(1): Apley I and Nassh N.Recurrent Abdominal Pains: A field survey of 1000 schoolchidren. Arch Dis Child 1958; 33: 165-170

(2): Apley J.The Child with Abdominal Pains. London, Blackwell Scientific Publications; 1959,2 nd edition 1975

(3): Heinild $\mathrm{S}$, Malver $\mathrm{E}$, Roelsgaard $\mathrm{G}$ and Worming $\mathrm{B}$. A psychosomatic approach to recurrent abdominal pain in childhood. Acta Paediatr Scand 1959; 48: 361-370.

(4): Green M. Diagnosis and treatment: Psychogenic, recurrent, abdominal pain. Pediatrics $1967 ; 40: 84-89$.

(5): Barr RG, Levine MD and Watkins JB. Recurrent abdominal pain due to lactose intolerance. New Engl J Med 1979; 300: 1449-1452.

(6): Liebman WM. Recurrent abdominal pain in children: Lactose and sucrose untolerance, a prospective study. Pediatrics 1979; 64: 43-45.

(7): Piñeiro-Carrero VM, Andres JM, Davis RH, Mathias JR. Abnormal gastroduodenal motility in children and adolescents with recurrent functional abdominal pain. $J$ Pediatr 1988; 113:820-825.

(8): van der Meer SB, Forget PP and Heidendal GAK. Small bowel pemeability to ${ }^{9} \mathrm{Cr}-$ EDTA in children with recurrent abdominal pain. Acta Paediatr Scand 1990; 79: 422 426.

(9): van der Meer SB, Forget PP, Arends JW, Kuijten RH and van Engelshoven JMA. Diagnostic value of ulltassound in children with recurrent abdominal pain. Pediatr Radiol $1990 ; 20: 501-503$

(10): van der Meer SB, Forget PP and Arends JW. Abnomal small bowel permeability and duodenitis in recurrent abdominal pain. Arch Dis Child 1990; 65: 1311 - 1314. (11): van der Meer SB, Forget PP, Kuijten RH and Arends JW. Gastroesophageal reflux and recurrent abdominal pain. Acta Paed Scand 1991; in press

(12): van der Meer SB, Forget PP, Loffeld RJLF, Stobberingh E, Kuijten RH and Arends JW. The prevalence Helicobacter pylori serum antibodies in children with recurrent abdominal pain. (submitted for publication)

(13): Crossley RB. Hospital admissions for abdominal pain in childhood. I Roy Soc Med 1982; $75 ; 772-776$

(14): Hodges $K_{*}$ Kline JJ, Barbero $G$ and Flanery R. Depessive symptoms in children with necurrent abdominal pain and in their families. J Pediatr 1985; 107: 622-626

(15): Feuerstein M, Bart RG, Francoeur TE, Houle $M$ and Rafman S. Potential biobehavional mechanisms of recurrent abdominal pain in children. Pain 1982; 13: 287298

(16): Peman JA, Barr RG and Watkins JB. Sucrose malabsorption in children: Noninvasive diagnosis by interval breath hydrogen determination. J Pediatr 1978; 93: 17-22. (17): Liebman WM. Recurrent abdominal pain in children: Lactose and sucrose intolenance, a prospective study. Pediatrics 1979; 64: 43-45.

(18): Lebenthal E, Rossi TM, Nord KS and Branski D. Recument abdominal pain and lactose absorption in children. Pediatrics 1981; 67: 828-832.

(19): Wald A, Chandra R, Fisher SE, Gartner JC and Zitelli B. Lactose malabsorption in recurrent abdominal pain of childhood. J Pediatr 1982; 100: 65-68. 
(20): Smart HL, Nicholson DA, Atkinson M. Gastro-oesophageal retlux in the imitable bowel syndrome. Gut 1986; 27: 1127-1131

(21): Dotevall G, Svedlund J, Ssjodin I. Symptoms in imtable bowel syndrome. Scand J Gastroenterol 1982; 17: suppl. 79: 16 - 19

(22): Dannaeus $A$, Johansson SGO, Foucard $T$ and Öhman $S$. Clinical and immunological aspects of food allergy in childhood. Acta Paediatr Scand 1977; 66: $31-37$.

(23): Crook WG a recument abdominal pain (letter). Am J Dis Child 1980; 134: 326-327. (24): Mahony MJ, WyattJ and Littewood JM. Campylobacter pyloni gastritis. Arch Dis Child 1988; 63: $654-655$

(25): Oderda G, Vaira D. Holton J, Dowsett JF and Ansaldi N. Serum pepsinogen and IgG antibody to Campylobacter pylori in non-specific abdominal. pain in childhood. Gut $1989 ; 30: 912-916$.

(26): Liebman WM. Recurrent abdominal pain in children: a retrospective study of 119 patients. Clin Pediatr 1978; 17: 149 - 153. 


\section{Summary and Conclusions}

The subject of Recurrent Abdominal Pain in children has drawn the attention of many investigators, particularly in the last 30 years. Pediatricians, psychologists and psychiatrists have reported their findings in the literature. Different aspects of the RAP syndrome, somatic as well as psychological, were investigated and discussed. Depending upon the point of view of the investigator, either somatic aspects predominated or psychological factors were thought to play the major role in the etiology of the patients' complaints. Since no one definite uniform cause could be detected, most authors agreed that the etiology of the RAP syndrome is multifactorial. The present most plausible and widely accepted idea is that in a number of patients a somatic cause can be found whereas in others a psychosomatic etiology is present. However, there still remains a large percentage of patients in whom neither somatic nor psychosomatic causes accounting for the abdominal complaints can be found. This patient group is most often regarded as presenting "dysfunctional" abnormalities. At present the percentages represented by these different groups in the total population of RAP patients is still open to discussion.

This thesis presents a prospective study performed in a group of 106 schoolchildren with Recurrent Abdominal Pain in the region of the city of Maastricht. In order to describe the historic perspectives of RAP in general and to give arguments for the design and aim of our present study, at review of the most important data conceming RAP is given in chapter 1.

The following chapters all deal with different aspects of the RAP syndrome.

In chapter 2 the results of a large scale psychological investigation of our study group are presented. These results were compared to those in a matched control group of schoolchildren. The majority of the psychological items tested, particularly those referring to personality traits, show no significant difference between study group and control group. Pain complaints in the children's fathers, stress-factors and signs of emotional distress were more frequent in the study group. We conclude that, except for the latter findings, there appear to be no essential differences on psychological grounds between children with RAP and control children. The differences found are not sufficient to explain the origin of RAP in children. The following four chapters all deal with somatic aspects of the RAP syndrome.

In chapter 3 the results of a small bowel permeability test with "Cr-EDTA as a marker are presented. Children with RAP appear to have a significantly higher urinary "Cr- 
EDTA excretion as compared to controls. In $54 \%$ of cases we found values higher than $3.5 \%$, considered to be the upper linit of the reference range in children. We conclude that the increased small bowel permeability in children with RAP might indicate an intestinal origin of the patients' complaints.

This possible intestinal etiology is further investigated in chapter 4. A number of patients from our study group underwent upper gastrointestinal endoscopy and duodenal biopsies. In $33 \%$ of the 39 patients investigated a duodenitis was observed. Furthermone, there appeared to be a significant relationship between duodenal inflammation and abnormal small bowel permeability. These findings give further evidence for an intestinal etiology of the patients' complaints. We proceeded to perform 24 -hour intraesophageal $\mathrm{pH}$ monitoring in 25 patients from the study group.

These results are presented in chapter 5 . In $57 \%$ of cases there appeared to be an abnormal pH monitoring, pointing to the presence of pathological gastroesophageal reflux. However, this abnormal $\mathrm{pH}$ monitoring was not related to the presence of an abnomal small bowel perneability or duodenal inflammation. Most notably, in 9 out of 14 parients with gastroesophageal reflux who were treated with antacids, the abdominal pain improved or resolved. We therefore concllude that gastroesophageal reflux is a frequent finding in children with RAP and that there might be a causal relationship between pathological gastroesophageal reflux and RAP.

Duodenal inflammation can be caused by viral or bacterial infection. Helicobacter" pylori has recently been found to be related to inflammatory bowel disorders such as gastritis and peptic ullcer disease. In chapter 6 we report the resulls of a study we performed among our patient group conceming the presence of serum antibodies to Helicobacter pylori by means of an enzyme-linked immuno assay. Out of 82 RAP patients $7(8.5 \%)$ presented antibodies to Helicobacter pylori, whereas this was the case in $2(5.1 \%)$ out of 39 control children. The observed prevalence of Helicobacter pylori serum antibodies in children with RAP is much lower than was suggested by previous reports in the literature. We conclude that past or present stigmas of Helicobacter pylori infection as measured by serology is similar in RAP and control children. Therefore, in our opinion Helicobacter pylori does not appear to play a major role in RAP in children.

The last two chapters of this thesis concem the diagnostic value of several additional investigations frequently carried out in children with RAP.

In chapter 7 the diagnostic yield of the ultrasound examination of the abdomen is presented. Routinely performed ultrasound examination of the abdomen did not appear to contribute to the diagnosis in children with RAP. However, ultrasound can still play a role in the work-up of children with RAP in avoiding unnecessary ndiologic $X-r i y$ procedures.

Finally, in chapter $\mathbf{8}$ the diagnostic contribution of "routine" laboratory investigations (haematology, clinical chemistry, occult blood, ova and parastes, urine sediment) in RAP is discussed. Our results show that "routine" laboratory investigations of blood, urine and stools do not contribute to the diagnosis in these patients. In contrast, the more sophisticated tests such as permeability tests, lactose breath hydrogen tests, upper gastrointestinal endoscopy and biopsy, $24 \mathrm{~h}$ pH monitoring, show somatic abnomalities in $42 \%$ of the total study group. We conclude that the presently used diagnostic approach for patients with RAP appears to be inadequate. By performing more sophisticated lests, an abnomality can be found in a much higher percentage of patients. In a flow-diagram at proposal is made for a new diagnostic approach for these patients. 
The main conclusions emerging from our present study are:

1). Psychological factors either primary or secondary to the conplaints can be relevant to the RAP patient, but that their role should not be overestimated leading to neglecting the role of somatic abnomalities.

2). We provide new evidence supporting the idea that the etiology of the complaints in RAP is probably of enteral origin. Specifically, the small bowel is likely to be involved. 3). Pathological gastroesophageal reflux is a frequent finding in children with RAP and might be causally related to the complaints.

4). Helicobacter pylori does not appear to play an important role in the etiology of RAP. 5). The present diagnostic approach towards patients with RAP seems to be ineffective and should probably be based upon more sophisticated laboratory investigations.

In general, children suffering from recurrent bouts of abdominal pain for longer than six months should be taken seriously by both the general practitioner and the specialist. Each patient should be entitled to a thorough physical examination and additional laboratory investigations. Considering our findings in the present study, we think that future scientific research concerning possible somatic abnormalities causing RAP in children should be directed towards food-related, infectious, immunologic and motility disorders. 


\section{0}

\section{Epilogue}

Investigating a frequently appearing complex of symptoms as well known in pediatric practice as the RAP syndrome is a serious challenge. At present, the syndrome is subject to discussion and will remain so after this studiy is finished. The many different aspects that might play a role in the etiology, primary or secondary, somatic or psychologic, have led to a broad spectrum of investigations in the past 30 years. Although these investigations did not always contribute to a better understanding of the syndrome, they clearly showed that many questions were still unanswered and that new ones had been raised. The group of children suffering from RAP is extremely heterogeneous, making interpretation of results from investigations often difficult. As a result a large number of patients are left without a diagnosis, and proper therapy is lacking. In other cases therapentical trials are unsuccessful or, when successful, are thought to be caused by placebo effects. The definition of RAP itself is often difficult. When should a child be diagnosed as suffering from RAP ? Which facts from a patient history should be decisive in categorizing this patient as having the RAP syndrome? Probably the one most decisive criterium is the duration of the complaints. All other possible criteria, ranging from severity of the complaints to the localization of the pain depend on the personal assessment of the attending doctor. In our own experience the child with RAP often presents relatively mild abdominal pain, and only rarely acute and severe attacks. The frequency of the attacks is very variable, ranging from every day to once a month. Most patients appear to have abdominal pain once or twice a week. The majority of patients are seen by a doctor when the pain has already been present for a long period of time. The attitude shown by the parents towards their child's complaints plays an important role when asking their general practitioner for advice.

At this point we go back to Paul and his parents, the patient we presented in the first chapter. When we first saw him he had had abdominal pain for more than a year. In the last few months the pain even had become worse and the attacks more frequent. Moreover, he had started to vomit often in association with an attick of abdominal pain. His parents, feeling very worried and unable to cope with Paul's behavior any longer, went to see a psychiatrist. Psychotherapy was started and the whole family became involved in the attempt to help Paul dispell his pains. After a few months of intensive psychotherapy some improvement was noticed. The vomiting stopped for sone time, but the attacks of pain did not. Paul's parents felt that he was hiding his complaints from them. They went back to their general practitioner. It was decided that in order to exclude 
organic abnomalities, Paul had to be seen by a pediatrician.

The pediatrician carrid out mary investigations. A blood sample was taken, urine and stools were checked and he underwent several other tests. Paul allso went to see a pxychologist for addirional tests. He had to be persuaded to cooperate at this point of the sudy. The results of all investigations appeared to be nomal except for a urine investigation that showed at raised excretion of what was called: "Cr-EDTA. The pediatrician explained to the parents that this could mean that the small bowel was "irritated" and expressed the need for further investigations. Paul was admitted to hospital, spending one night at the pediatric clepartment. For 24-hours he walked around and slept with a thin catheter through his nostril. The day after, he underwert a "look" inside-investigation". This was not a pleasant experience for him, it made him vomit and it hurt. Both investigations revealed abnomalities. In other words: he had an abnormal pH-monitoring, pointing to the presence of pathological gastroesophageal reflux. Furthermore, his small bowel was indeed irritated, appearing red at endoscopy, and histology showed a duodenitis.

The doctor explained these findings to Paul and his parents in plain, non-medical language. He advised that Paul sleep in anti-Trendelenburg and that he take a medicine after every meal and before going to bed.

When after a few weeks Paul and his mother were seen again at the outpatient clinics, they reported that the abdominal pain had gradually disappeared after one or wo weeks. Paul had never fell better in his "whole life". The therapy was continued for a few months and then gradually stopped. The abdominal pain did not reappear and Paul was discharged after a 9 months follow-up.

Paul's story is a rather good example illustrating the classical picture presented by a child with RAP. It is a case report on one of our patients from the study group. Paul is not an exceptional case. Based on our results it is our contention that the search for somatic abnomalities deserves more attention than it receives at present. Without expressing the need for overwhelming investigations, we teel that a child with RAP for longer than 6 months is entitled to a thorough physical examination and additional investigations. From our results a protocol can be drawn consisting of a relatively low-budget set of investigations which are mostly well-tolerated by the children. Moreover, our findings have indicated that a large part of the so-called "routine" laboratory investigations are not helpful in excluding possible somatic disorders and could therefore be omitted in the work-up of chitdren with RAP. In contrast, the high percentage of positive findings at endoscopy and $\mathrm{pH}$ monitoring in children with RAP, favors this kind of investigations. The psychological part of the investigations can be of help in understanding the possible rolle of psychological factors in the patient's complaints. When overt psychological disturbances are present and somatic disease bas been ruled out in so far as possible, psychological treatment for these disturbances is indicated. Furthemore, the presence of a combination of a somatic disorder with psychological disturbances and/or complications should not be overlooked.

New developments in the field of pediatric gastroenterology will certainly result in changes of atitude towards disorders such as the RAP syndrome. The present study might help in creating part of this change. Too many children are still suffering from RAP for too long, without being properly investigated. There is a need for further investigations concerning the pathogenesis of RAP in children. It is most likely that this pathogenesis is multifactorial and that the complaints can not be attributed to one single disorder. Therefore, scientific research should be directed towands a broad spectrum of 
possible causes for the RAP syndrome. These causes night appear to be related to one another or they could be presenting symptoms of a different, more hidden, abmomality. The investigation of patients with RAP remains an interesting challenge. In every average classroom there are 3 children suffering from recurren abdominal pain. Considering this number of children, it seems obwious that this subject deserves much more attention than it has recieved up till now. 


\section{Samenvatting en Conclusies}

Chronisch Recidiverende Buikpijn (CRB) bij kinderen heeft, met name de laatste 30 jaar, de aandacht van talrijke onderzoekers getrokken. Kinderartsen, psychologen en psychiaters hebben hun bevindingen in de wetenschappelijke literatuur gerapporteerd. De verschillende aspecten van het CRB syndroom, zowel lichamelijke als psychologische, zijn onderzocht en bediscussieerd. Afhankelijk van het standpunt van de onderzoeker zijn of lichamelijke factoren benadrukt dan wel psychologische factoren geacht de voornaamste rol te spelen bij de oorzaak van de klachten van de patienten. Een eensluidende oorzaak is niet aangetoond en de meeste auteurs zijn het er over cens, dat de oorzaak van hel CRB syndroom berust op verschillende factoren. De thans meest geloofwaardige en breedst geaccepteerde overtuiging is, dat bij cen deel van de patienten een lichamelijke oorzaak gevonden kan worden, terwijl bij andere patienten een psychosomatische oorzaak aantoonbaar is. Er resteert echter een groot aantal patienten, waar noch een lichamelijke noch een psychosomatische oorzaak gevonden kan worden, die een verklaring voor de buikpijnklachten kan geven. Deze groep patienten wordt meestal aangeduid als lijdend aan "dysfunctionele" afwijkingen. De vraag echter blijft hoe groot deze 3 verschillende groepen zijn binnen de totale groep van kinderen met CRB.

Dil proefschrift beschrijft een studie die wij hebben werricht bij een groep van 106 schoolkinderen met Chronisch Recidiverende Buikpijn in de regio Maastricht.

In hoofdstuk 1 wordt een overzicht gegeven van de belangrijkste literatuur gegevens met betrekking tot CRB teneinde de historische aspecten van dit eerder genoemde syndroom in het algemeen en argumenten voor de opzet en het doel van deze studie uiteen te zetten.

In hoofdstuk 2 worden de resultaten van het psychologisch onderzoek van onze studiegroep gepresenteerd. Deze resultaten hiervan zijn vergeleken met die van een vergelijkbare controlegroep gezonde schoolkinderen. Het merendeel der psychologische factoren die onderzocht zijn, met name de factoren die betrekking hebben op de persoonlijkheid, laten geen verschil van betekenis zien tussen de studie- en de controlegroep. Pijnklachten bij de vaders van de buikpijnkinderen, stressfactoren en tekenen van emotionele distress kwamen vaker voor bij kinderen met buikpijn. Wij concluderen dat, afgezien van de bovengenoemde bevindingen, er geen essentiële verschillen op psychologische gronden bestaan tussen kinderen met CRB en gezonde controlekinde- 
ren. In de vier hiema volgende hoofdstukken wordt een uiteenzetting gegeven van de lichamelijke aspecten van het CRB syndroom:

Hoofdstuk 3 beschrijft de resultaten van een darmioorlaabaaneidstest. De darmdoorlaatbaarheid bljkt bij kinderen met CRB bedurdend hoger te zijn vergeleken met die van. controlekinderen. In 54\% van de gevallen hebben wij watrden gevonden hoger dan $3.5 \%$, hetgeen beschouwd wordt als de limiet van normatal bij kinderen. Waj concluderen, dat de verhoogde damdoorlaatbaarheid bij kinderen met CRB kan wijzen op damafwijkingen als oorsprong van de klachten.

Deze darmafwijkingen zijn verder onderzocht in hoofdstuk 4. Een deel van de patienten heeft een kijkonderzoek ondergaan van de slokdam, mag en dunne darm, watabij tevens een stukje slijmvlies van de dunne dam is weggenomen voor nader onderzok. In $33 \%$ van de 39 onderzochte patienten is een ontsteking van de dunne darm wargenomen. Ook blijkt er een verband te bestaan tussen dume darm ontsteking en abnomale darmdoorlaatbaarheid. Deze bevindingen hebben een verdere aanwijzing gegeven voor darmafwijkingen als oorzaak van de klachten van de patienten.

Vervolgens is el gedurende 24 unr en zungratadmeting van de slokdarm verricht bij 25 patienten. De resultaten hiervan worden uiteengezet in hoofdstuk 5. In 57\% van de gevallen blijkt er een afwijkende zurgrad te bestaan in de slokdarm, deze wijst op een abnormale terugvloed van magzzur in de slokdarm. Deze eendergenoemde zumrgrad houdt echter geen verband met de aanwezigheid van een abnormale darmdoorkatbaarheid of darmontsteking. Zeer opmerkelijk is, dat bij $71 \%$ van de patienten mer een afwijkende zuurgraad die behandeld is met magzuumiddelen, de buikpijn verminderd of verdwenen is. Wij concluderen dan ook, dat een abnomale zuurgraad van de slokdarm vaak wordt wargenomen bij kinderen met CRB en dat er een oorzakelijk verband kan bestaan tussen deze zuurgraad en de buikpijnklachten.

Dunne darmonsteking kan worden veroorzaakt door infecties met virussen of bacteriën. Recentelijk is er een verband aangetoond tussen de zogenoemde Helicobacter pylori en maagslijmvliesontsteking, maagzweren en zweren van de twaslfvingerige dam. In hoofdstuk 6 geven wij de resultaten weer van een studie die wij verricht hebben bij onze. patientengroep betreffende de aanwezigheid van antistoffen hiertegen. Van de 82 patienten met CRB blijken er 7 (8.5\%) antistoffen tegen Helicobacter pylori te bezitten. terwijl dit bij 2 (5.1\%) wan de 39 controlekinderen het geval is. Het voorkomen van Helicobacter pylori antistoffen bij kinderen met CRB is veel lager dan gesuggereerd wordt in eerdere berichten in de literatum. Wij concluderen, dat Helicobacter pylori infecties even vaak voorkomen bij kinderen met als zonder CRB. Naar onze mening speelt Helicobacter pylori dan ook geen belangrijke rol bij kinderen met CRB.

De laatste wee hoofdstukken van dit proefschrift beschrijven de diagnostische waarde van verschillende laboratorium onderzoekingen die vaak worden witgevoerd bij kinderen met CRB.

Het diagnosisch rendement van het echografisch onderzoek van de buik wordi in hoofdstuk 7 beschreven. Het uitvoeren wan routinematig echografisch onderzoek van de buik blijkt geen bijdrage te leveren aan het stellen van de diagnose bij kinderen met CRB. Echografisch onderzoek kan echter aanvullend (stralen)belastend röntgenonderzoek overbodig maken.

Ten slotte wordt in hoofdstuk 8 over de diagnostische bijdrage van "routine" laboratoriumonderzoeken zoals bloedonderzoek, bloedverlies en wormen bij de onllasting. urineonderzoek, bij CRB gediscussieerd. Onze resultaten geven aan, dat de "rouline" laboratorium onderzoeken van bloed, urine en ontlasting geen bijdrage leveren an het 
stellen van de diagnose bij deze patienten. Darrentegen laten de meer verfijnde onderzokingen, zoals darndoorlatbatheidstesten, waterstofmetingen in de uitademingslucht, kjjkonderzoek van de slokdarm, maag en dunre darm en zuurgraadmetingen, lichamelijke afwijkingen zien in $42 \%$ van de totale patiëntengroep. Wij concluderen dat de hudige diagnostische benadering van patienten met CRB niet doelmatig blijk te zijn. Echter, net behulp van meer verfinde onderzoekingen kan bij een veel hoger percentage van de patienten een afwijking worden gevonden. In een stroomdiagram wordt en voorstel gedaan woor een nieuwe diagnostische benadering van deze patienten.

Ten slotte resumeren wij de voornaamste conclusies van dit onderzoek:

1). Psychologische factoren, zowel primair als secundair, kunnen belangrijk zijn bij de CRB patient. De rol van psychologische factoren moet echter niet moeten worden overschat en mag niet leiden tot het verontachtzamen wan de rol van lichamelijke afwijkingen.

2). Aangetoond is dat darmafwijkingen mogelijk een belangrijke rol spelen bij de oorzaak van de klachten. Vooral de dunne darm lijkt betrokken te zijn bij de oorzaak van CRB.

3). Een atbnomale zuurgraad in de slokdarm wordt vaak gevonden bij kinderen met CRB en er is een mogelijk oorzakelijk verband met de klachten.

4). Helicobacter pylori blijkt geen belangrijke rol te spelen bij de oorzaak van CRB.

5). De huidige diagnostische benadering van patiënten met CRB lijkt niet doelmatig te. zijn en deze zou waarschijnlijk gebaseerd moeten zijn op meer verfijnde laboratorium. onderzoeken.

In het algemeen moeten kinderen met chronisch recidiverende aanvallen van buikpijn, langer bestaand dan zes maanden, serieus genomen worden zowel door de huisarts alls de specialist. ledere patient verdient een grondig lichamelijk onderzoek en aanvullende laboratorium onderzoeken. Toekomstig wetenschappelijk onderzoek betreffende mogelijk lichamelijke afwijkingen als oorzaak van CRB bij kinderen zou, gelet op de bevindingen van deze studie, gericht moeten worden op voedingsathankelijke factoren, intectieuze-, immunologische- en darmbewegingsafwijkingen. 


\section{Gearfetting en Konklúzjes}

Groanysk Residivearjende Pinebûk (GRP) by bern hat, benammen de lêste 30 jier, tigè de oandacht lutsen fan gâns ûndersikers. Bernedoktors, psychologen en psychiaters hawwe harren befinings yn "e wittenskiplike literatuer rapportearre. De ûnderskate aspekten fan it GRP-syndroom, lichaamlike sawol as psychologyske, binne tindersocht en bediskussearre. Al neffens it stânpunt fan 'e ûndersiker walard de klam lein op lichamlike faktoaren of spilen psychologyske faktoaren de wichtichste rol by de carsaak fan "e klachten fan 'e pasjinten. In gelikense oarsaak is net oantoand en de measte auteurs binne it deroer iens, dat de oarsaak fan it GRP-syndroom op underskate faktoaren berêst. De oertsjinging dy't hjoeddedei yn brede rûnten oanhongen en akseptearre wurdt. is, dat by in part fan 'e pasjinten in lichaamlike oarsatak fîn wurde kin, wylst by oare pasjinten in psychosomatyske oarsaak oantoand wurde kin. In grut tal pasjinten bliuwt lykwols oer, by wa"t noch in lichaamlike noch in psychosomatyske oarsaak fûn wurde kin, dy"t in ferklearring jaan kin foar de klachten oer pinebûk. Dy groep fan pasjinten wurdt meastentiids oantsjut as lêst hawwend fan "dyfunksjonele" of wikingings. De fraach bliuwt lykwols hoe grut dizze trije ûngelikense groepen binne binnen de totale groep fan bern mei GRP.

Dit proefskrift is in beskriuwing fan in stuidzje dy't wy dien hawwe by in groep lan 106 skoalbern mei Groanysk Residivearjende Pinebûk yn "e krite Maastricht.

Yn haadstik 1 wurdt in oersjoch jûn fan "e wichtichste literatuergegevens oangennde GRP mei it doel de histoaryske aspekten fan dit earderneande syndroom yn it algemien en arguminten foar de opset en it doel fan dizze stúdzje nei foaren te bringen.

Yn haadstik 2 wurde de resultaten fan it psychologysk undersyk fan ús stúdzjegroep presentearre. Dy resultaten binne ferlike mei dy fan in ferlykbere kontrôlegroep sûne skoalbern. It meastepart fan 'e psychologyske faktoaren dy't andersocht binne, benammen de faktoaren dy't fan dwaan hawwe mei de persoanlikheid, litte giin ferskil fan betsjutting sjen tusken stúdzje- en kontrôlegroep. Pineklachten by heiten fan pinebûkbern, stressfaktoaren en tekens fan emosjonele distress kamen faker foar by bern mei pinebûk. Wy konkludearje dat, ofsjoen fan boppeneamde befiningen, der gjin essensjele ferskillen op psychologyske grîmen bestean tusken bern mei GRP en sûne kontrôlebern. $\mathrm{Yn}$ 'e' fjouwer folgjende haadstkken wurdt útlis jûn fan 'e lichaamlike aspekten fan it GRP syndroom.

Haadstik 3 beskriuwt de resultaten fan in terntrochlitberheidstest. De termitrochlitber- 
heid blykt by bern mé GRP oanmerklik heger te wêzen as by kontrolebem. Yn $54 \%$ fan "e gefallen hawwe wy wearden fün heger as 3.5\%, wat beskoge wurd as de limyt fan normaal by bem. Wy komme ta de konklúzje dat de hegere termtrochliberheid by bem mel GRP wize kin op termôfwikings as oarsprong fan "e klachten.

Dy termôfwikings binne fierder ûndersocht yn haadstik 4 . In part fan te pasjinten hat in kykûndersyk ûndergien fan 'e slokterm, mage en fine term, wêrby"t ek in stikje slymflues fan $\mathrm{e}$ fine term weinommen is foar fierder ondersyk. Yn 33\% fan "e 39 ândersochte pasjinten is in untstekking fan 'e fine tem waanommen. Ek docht bliken un ferbân te bestean tusken fine termûntstekking en abnomale termtrochlitberheid. Dy útkomsten hawwe in fierder oanwizing jôn foar termôfwikings as oarsaak fan 'e kilachten fan 'e pasjinten.

Boppedat is der 24 oeren llang in soergraadmjitting fan "e slokterm dien by 25 pasjinten. De resultaten dêrfan wurde útinoarset yn haadstik 5 . Yn $57 \%$ fan 'e gefallen blykt der ofwikende soergraad te bestean yn "e slokterm, dy't wist op in abnormale tebekrin fan maachsoer yn "e slokterm. Dy eardemeande soergraad hâldt lykwols gjin ferbân mei de oanwêzigens fan in abnormale termtrochlitberheid of termûntstekking. Tige nijsgjimich is dat by $71 \%$ fan "e pasjinten mei in ofwikende soergraad dy't behannele is mei maachsoermiddels, de pynyntliff fermindere of ferdwuin is. Wy konkludearje dan ek, dat in abnomalle soergraad fan "e slokterm gauris opmurken wurdt by" bem mei GRP en dat der in oarsaaklik ferbân bestean kin tusken dy soergraad en de pinebûkklachten.

Fine termûntstekking kin troch ynfeksjes mei finussen of baktearjes feroarsake wurde. Koartby is oantoand dat der in ferbân is tusken de saneamde Helicobacter pylori en maachfluesantstekking, maachswolms en swolderij oan "e koarte term. Yn haadstik 6 jouwe wy de resultaten wer fan in stúdzje dy"t wy dien hawwe by ús pasjintegroep op it oanwêzich wêzen fran antystoffen dêrtsjin. Fan 'e 82 pasjinten mei GRP blike $7(8.5 \%)$ antystoffen tsjin Helicobacter pylori te hawwen, wylst dat by $2.5 .1 \%)$ fan "e konirôlebern it gefal is. It foarkommen fan Helicobacter pylori-antystoffen by bem mei GRP is folle leger as suggerearre wurdt yn eardere berjochten yn 'e literatuer. Wy konkludearje dat Helicobacter pyloni-ynleksjes likefaak foarkomme by bern mei as sûnder GRP. Nei ús betinken spilet Helicobacter pylori sadwaande ek giin wichtiche rol by bem mei GRP. De beide lêste haadstikken fan dit proefskrift beskriuwe de diagnostyske wearde fan onderskate laboratoriumundersiken dy't faak ütfierd wurde by bern mei GRP. Il diagnostysk rendemint fan it echogralysk oindersyk fan it lif wurdt yn haadstik 7 beskreaun. It dwaan fan echografysk rutineundersyk fan in liff blykt net by te dragen ta it stellen fan de diagnoaze by bern mei GRP. Echografysk ôndersyk kin lykwols oanfoljend (strielings)belêstigjend rơntgenündersyk oerstallich meitsje.

As lêste wưdt yn haadstik 8 de diagnostyske bydrage fan "rútine" - laboratoriumundersiken lykas bloedundersyk, bloedferlies en wjirmen by de ûntlêsting, urineûndersyk, by GRP besprutsen. Us resultaten jouwe oan, dat de "rûtine" - laboratoriumandersiken fan bloed, urine en trochgong gin bydrage leverje ta it stellen fan " $\mathrm{e}$ diagnoaze by dizze pasjinten. Dêrfoaroer litte de mear ferfine ândersikings lykas termtrochlitberheidstesten, wetterstofmjittings yn "e útazemingslucht, kykûndersyk fan " $\mathrm{e}$ sloklerm, mage en fine term en soergradmjitings, lichaamlike ofwikings sjen yn $42 \%$ fan 'e totale pasjintegroep. Wy komme ta de konklúzje dat de hjoeddeiske diagnostyske oanpak fan pasjinten mei GRP net doelmjittich blykt te wêzen. Mei help fan mear ferfine ûndersikings kin lykwols by in folle heger persintaazje fan 'e pasjinten in ofwiking fuin wurde. Yn in streamdiagram wurdt in útstel dien foar in nije diagnostyske oanpak fan dy pasjinten. 
Ta beshút fetsje wy de wichtichste konklúzjes fan dit ündersyk gear:

1). Psychologyske faktoaren, likegoed primêr as sekundêr, kinne fan belang wêz by de GRP-pasjint. De roll fan psychologyske faktoaren moat bywols net oerskat wurte en mei net liede ta it net achtslaan fan "e rol fan lichaamlike ofwikings.

2). Der is oantoand dat temôfwikings mooglik in wichtiche rol spylje by de oarsaak fan 'e klachten. Benammen de fine term liket behelle te wêzen by de oarsak lan GRP.

3). In abnomale soergraad yn 'e slokterm wurdt gauris fü by bern mei GRP en der is mooglik oarsaaklik ferbân mei de klachten.

4). Helicobacter pylori docht bliken gjin rol fan belang te spyljen by de oarsak fan GRP.

5). De hjoeddeiske diagnostyske oanpak fan pasjinten mei GRP blykt not doelmjittich te wêzen en soe nei alle gedachten berêste moatte op mear fertine laboratoriumûndersiken.

Oer it generaal moatte bem mei groanysk residivearjende oanfallen fan pinebûk, langer as 6 moanne foarkommend, serieus nommen wurde troch de húsdokter en de spesjalist beide. Elke pasjint fertsjinnet in yngeand lichaamlik undersyk en oanfoljende laboratoriumûndersiken. Takomstich wittenskiplik undersyk oangeande mooglik lichaamlike ôfwikings as oarsaak fan GRP by bem soe, sjoen de útkonsten fan dizze stúdzje, rjochte wêze moatte op faktoanen dy't mei it iten gearhingje, op ynfeksjeuze, ymmunologyske en termbewegingsôfwikings. 


\section{Curriculum Vitae}

De auteur werd geboren op 19 november 1953 te Witmarsum (Friesland). Bezocht de Rijkshogereburgerschool te Leeuwarden en ging vervolgens Geneeskunde studeren aan de Katholieke Universiteit te Nijmegen. Hij behaalde zijn artsdiploma in november 1981. Van januari 1982 tot december $\mathbb{1 9 8 6}$ werd hij opgeleid tot kinderarts in het toenmalige Ziekenhuis St. Annadal te Maastricht (opleider: Prof.Dr. L.H.J. Ramaekers). Sinds januari 1987 is hij als staflid verbonden aan de afdeling Kindergeneeskunde van het Academisch Ziekenhuis Maastricht, als chef de policlinique. 